Florida International University FIU Digital Commons

$1-13-2012$

\title{
The Role of Redox Signaling in the Molecular Mechanism of Tamoxifen Resistance in Breast Cancer
}

Nana Aisha Garba

Florida International University, ngarb002@fiu.edu

DOI: $10.25148 /$ etd.FI12041102

Follow this and additional works at: https://digitalcommons.fiu.edu/etd

\section{Recommended Citation}

Garba, Nana Aisha, "The Role of Redox Signaling in the Molecular Mechanism of Tamoxifen Resistance in Breast Cancer" (2012). FIU Electronic Theses and Dissertations. 551.

https://digitalcommons.fiu.edu/etd/551 


\title{
FLORIDA INTERNATIONAL UNIVERSITY
}

Miami, Florida

TAMOXIFEN RESISTANCE IN BREAST CANCER.

\author{
A dissertation submitted in partial fulfillment of the \\ requirements for the degree of \\ DOCTOR OF PHILOSOPHY \\ in \\ PUBLIC HEALTH \\ by \\ Nana Aisha Garba \\ 2012
}


To: Interim Dean Michele Ciccazzo

Robert Stempel College of Public Health and Social Work

This dissertation, written by Nana Aisha Garba, and entitled The Role of Redox

Signaling in the Molecular Mechanism of Tamoxifen Resistance in Breast Cancer, having been approved in respect to style and intellectual content, is referred to you for judgment.

We have read this dissertation and recommend that it be approved.

Quentin Felty

Jai Parkash

Ophelia Weeks

Deodutta Roy, Major Professor

Date of Defense: January 13, 2012

The dissertation of Nana Aisha Garba is approved.

Interim Dean Michele Ciccazzo Robert Stempel College of Public Health and Social Work

Dean Lakshmi N. Reddi University Graduate School

Florida International University, 2012 


\section{DEDICATION}

To my mother, Fatima Omonego Garba and My Son

Jayden Dangtiem Dama, whom I pray will exceed all of my accomplishments, and regard this dissertation as evidence that the sky is his limit. 


\section{ACKNOWLEDGMENTS}

I gratefully acknowledge the support and encouragement of my family and friends over the years. My journey would have been more uphill without every single one of you. I wish to thank my major professor, Dr. Deodutta Roy and members of my committee Dr. Quentin Felty, Dr. Jai Parkash, and Dr. Ophelia Weeks for their invaluable advice and time commitment. I am also grateful to the University Graduate School for providing me with the dissertation year fellowship which enabled me to complete my dissertation in a timely manner. 


\title{
ABSTRACT OF THE DISSERTATION \\ THE ROLE OF REDOX SIGNALING IN THE MOLECULAR MECHANISM OF TAMOXIFEN RESISTANCE IN BREAST CANCER.
}

\author{
by \\ Nana Aisha Garba \\ Florida International University, 2011 \\ Miami, Florida \\ Professor Deodutta Roy, Major Professor
}

The emergence of tamoxifen or aromatase inhibitor resistance is a major problem in the treatment of breast cancer. The molecular signaling mechanism of antiestrogen resistance is not clear. Understanding the mechanisms by which resistance to these agents arise could have major clinical implications for preventing or circumventing it. Therefore, in this dissertation we have investigated the molecular mechanisms underlying antiestrogen resistance by studying the contributions of reactive oxygen species (ROS)-induced redox signaling pathways in antiestrogen resistant breast cancer cells. Our hypothesis is that the conversion of breast tumors to a tamoxifen-resistant phenotype is associated with a progressive shift towards a pro-oxidant environment of cells as a result of oxidative stress. The hypothesis of this dissertation was tested in an in vitro 2-D cell culture model employing state of the art biochemical and molecular techniques, including gene overexpression, immunoprecipitation, Western blotting, confocal imaging, ChIP, RealTime RT-PCR, and anchorage-independent cell growth assays. We observed that tamoxifen (TAM) acts like both an oxidant and an antioxidant. Exposure of tamoxifen resistant LCC2 cell to TAM or 17 beta-estradiol (E2) induced the formation of reactive 
oxidant species (ROS). The formation of E2-induced ROS was inhibited by co-treatment with TAM, similar to cells pretreated with antioxidants. In LCC2 cells, treatments with either E2 or TAM were capable of inducing cell proliferation which was then inhibited by biological and chemical antioxidants. Exposure of LCC2 cells to tamoxifen resulted in a decrease in p27 expression. The LCC2 cells exposed to TAM showed an increase in p27 phosphorylation on T157 and T187. Conversely, antioxidant treatment showed an increase in p27 expression and a decrease in p27 phosphorylation on T157 and T187 in TAM exposed cells which were similar to the effects of Fulvestrant. In line with previous studies, we showed an increase in the binding of cyclin E-Cdk2 and in the level of p27 in TAM exposed cells that overexpressed biological antioxidants. Together these findings highly suggest that lowering the oxidant state of antiestrogen resistant LCC2 cells, increases LCC2 susceptibility to tamoxifen via the cyclin dependent kinase inhibitor p27. 


\section{TABLE OF CONTENT}

CHAPTER

I. INTRODUCTION

Hypothesis and Specific Aims

1

3

II. LITERATURE REVIEW: THE ROLE OF REDOX SIGNALING IN THE MOLECULAR MECHANISM OF TAMOXIFEN RESISTANCE IN BREAST CANCER TREATMENT

Abstract

Overview of Estrogen/ Estrogen receptor(ER) actions

Anti-estrogens: Tamoxifen

Redox signaling

$17 \beta$-estradiol (Estrogen) induces ROS formation

Tamoxifen induces ROS formation

Tamoxifen as a scavenger of ROS

The role of Oxidative stress and redox signaling

Chemistry of ROS

Oxidative modification of proteins

Redox signaling and its effect on signaling pathways

The effect of ROS on transcription factors

NRF-1

Cell Cycle

The role of redox signaling in anti-estrogen resistance

References

Acknowledgments

Figures and Legend

4

4

5

10

11

15

18

19

19

22

22

23

32

34

40

46

48

75

76

III. REDOX SIGNALING CONRIBUTES TO THE DEVELOPMENT OF TAMOXIFEN RESISTANCE IN BREAST CANCER TREATMENT

Abstract

79

Introduction

81

Materials and methods $\quad 85$

Results

91

Discussion $\quad 97$

References 100

$\begin{array}{ll}\text { Figures and Lengend } & 104\end{array}$

IV. ESTROGEN INDUCED ROS MEDIATES IN VITRO CELL PROLIFERATION AND GROWTH THROUGH PTEN OXIDATION AND AKT-NRF-1 PHOSPHORYLATION

Abstract

Introduction 
$\begin{array}{lr}\text { Materials and methods } & 119\end{array}$

Results 125

$\begin{array}{lr}\text { Discussion } & 128\end{array}$

$\begin{array}{lr}\text { References } & 130\end{array}$

$\begin{array}{ll}\text { Figures and Legend } & 132\end{array}$

V. CONCLUSION 141

$\begin{array}{ll}\text { Direction for future research } & 145\end{array}$

$\begin{array}{ll}\text { VITA } & 146\end{array}$ 


\section{LIST OF FIGURES}

FIGURE

PAGE

1-R Redox reactions involving hydrogen peroxide and a thiolate $\quad 76$

2-R Oxidation of Prx by $\mathrm{H}_{2} \mathrm{O}_{2}$

3-R Reversible PTP inactivation by $\mathrm{H}_{2} \mathrm{O}_{2}$

4-R The effect of E2-induced ROS on regular mitogenic signaling 78

5-R The effect of Tamoxifen-induced ROS on regular mitogenic signaling $\quad 79$

1-LCC2 Antioxidants mitigate ROS formation in TAM resistant LCC2 cells

2-LCC2 Antioxidants inhibit BrdU incorporation in TAM resistant cells 105

3-LCC2 Antioxidants mitigate anchorage independent growth in TAM resistant LCC2 cells

4-LCC2 Antioxidants Increased p27 expression in TAM Resistant cells 107

5-LCC2 Antioxidants decreased p27 phosphorylation in TAM Resistant cells

6-LCC2 Prolonged antioxidant treatments increased p27 expression in LCC2 cells

7-LCC2 Prolonged exposure of LCC2 cells to Antioxidants decreased p27 phosphorylation in LCC2

8-LCC2 Antioxidants Increased p27 binding to CylinE and CDK2 in TAM resistant cell

9-LCC2 Antioxidants Increased CDK2 binding to CylinE and p27 in TAM resistant cells

10-LCC2 Antioxidant Increased CylinE binding to CDK2 and p27 in TAM resistant Cells 
12-LCC2 Antioxidants increased p27 stability 115

1-MCF7 Antioxidants inhibit E2 induced ROS in MCF7 cells 132

2-MCF7 Antioxidants inhibit DNA synthesis in MCF7 cells 133

3-MCF7 Antioxidants inhibit E2-induced anchorage independent growth in MCF7 cells

4-MCF7 Hydrogen Peroxide $\left(\mathrm{H}_{2} \mathrm{O}_{2}\right)$ oxidizes PTEN in a dose dependent manner in MCF7 cells

5-MCF7 Antioxidants inhibit the E2-induced PTEN oxidation in MCF7 cells

6-MCF7 E2-induced PTEN oxidation activates Akt phosphorylation in MCF7 cells

7-MCF7 E2 induces NRF1 expression and phosphorylation in MCF7 cells 138

8-MCF7 E2-induced ROS mediates NFR-1 binding to the promoter region of cell cycle genes

9-MCF7 E2-induced ROS mediates transcription of cell cycle genes $\quad 140$

10-MCF7 A schematic showing our hypothesized pathway 141 


\section{LIST OF ACRONYMS}

\begin{tabular}{|c|c|}
\hline $\mathrm{AE}$ & Anti-estrogen \\
\hline AI & Aromatase Inhibitor \\
\hline AP-1 & Activated protein 1 \\
\hline ARE & Antioxidant response element \\
\hline ATP & Adenosine Triphosphate \\
\hline $\mathrm{Cdk}$ & Cyclin-dependent kinase \\
\hline CDKI & Cyclin dependent kinase inhibitor \\
\hline CIP/KIP & Cdk inhibiting and kinase inhibiting proteins \\
\hline CREB & cAMP response element-binding \\
\hline Cys & Cysteine \\
\hline DNA & Deoxyribonucleic acid \\
\hline DTT & Dithiothreitol \\
\hline DUOX1 & Dual oxidase 1 \\
\hline E2 & $17 \beta$-estradiol \\
\hline EGFR & Epidermal growth factor receptor \\
\hline EGF & Epidermal growth factor \\
\hline ER & Estrogen receptor \\
\hline $\mathrm{ER} \alpha$ & Estrogen receptor alpha \\
\hline $\mathrm{ER} \beta$ & Estrogen receptor beta \\
\hline ERE & Estrogen response element \\
\hline ERK & Extracellular signaling kinase \\
\hline $\mathrm{ER}+$ & Estrogen receptor positive \\
\hline
\end{tabular}




\begin{tabular}{|c|c|}
\hline FOXO & Forkhead box class $\mathrm{O}$ \\
\hline GPCR & G-protein-coupled receptors \\
\hline GSSG & Glutathione disulfide \\
\hline GSH & Glutathione \\
\hline GPx & Glutathione Peroxidase \\
\hline HBV & Hepatitis B virus \\
\hline $\mathrm{H}_{2} \mathrm{O}_{2}$ & Hydrogen peroxide \\
\hline HUVEC & Human umblical vein and endothelial cells \\
\hline IGF-IR & Insulin-like growth factor I receptor \\
\hline IP3 & Inositol trisphosphate \\
\hline LOO & Peroxyl radicals \\
\hline MAPK & Mitogen activating protein kinase \\
\hline MKP & Mitogen activated protein kinase phosphatase \\
\hline NADPH & Nicotinamide adenine dinucleotide phosphate-oxidase \\
\hline NRF-1 & Nuclear respiratory factor 1 \\
\hline $\mathrm{O}_{2}^{--}$ & Superoxide \\
\hline${ }^{1} \mathrm{O}_{2}$ & Singlet oxygen \\
\hline $\mathrm{OH}^{-}$ & Hydroxyl radical \\
\hline $\mathrm{ONOO}^{-}$ & Peroxynitrite \\
\hline PDGF & Platelet derived growth factor \\
\hline Prx & Peroxiredoxin \\
\hline PTEN & Phosphatase and tensin homolog \\
\hline PTK & Protein tyrosine kinase \\
\hline
\end{tabular}




\begin{tabular}{|c|c|}
\hline РTP & Protein tyrosine phosphatase \\
\hline PTP1B & Protein-tyrosine phosphatase 1B \\
\hline PI3K & Phosphatidylinositol 3-kinases \\
\hline LMW-PTP & Low molecular weight PTP \\
\hline RNA & Ribonucleic acid \\
\hline RNS & Reactive nitrogen species \\
\hline ROS & Reactive oxygen species \\
\hline $\mathrm{RS}^{-}$ & Thiolate \\
\hline RSH & Thiol \\
\hline $\mathrm{RSO}^{-}$ & Sulfenate \\
\hline RTK & Receptor Tyrosine Kinase \\
\hline SERD & Selective estrogen receptor downregulator \\
\hline SERM & Selective estrogen receptor modulator \\
\hline$-\mathrm{SO}_{2} \mathrm{H}$ & Sulfinate \\
\hline$-\mathrm{SO}_{3} \mathrm{H}$ & Sulfonate \\
\hline SAPK & Stress activated protein kinase \\
\hline $\mathrm{TNF} \alpha$ & Tumor necrosis factor alpha \\
\hline $\mathrm{Mn}(\mathrm{SOD})$ & Superoxide dismutase \\
\hline $\mathrm{NF} \kappa \mathrm{B}$ & Nuclear factor kappa-light-chain-enhancer of activated B cells \\
\hline NRF-1LKO & NRF-1 liver knock-out \\
\hline $\mathrm{NO}_{2}$ & Nitrogen dioxide \\
\hline $\mathrm{NO}$ & Nitric oxide \\
\hline TAM & Tamoxifen \\
\hline
\end{tabular}


TGF $\alpha \quad$ Transforming growth factor beta 1

TGF $\beta 1 \quad$ Transforming growth factor beta 1

Trx Thioredoxin

4-OHT 4-hydroxy-tamoxifen 


\section{INTRODUCTION}

The fact that a majority of breast cancer express estrogen receptor alpha (ER $\alpha)$, has informed the use of antiestrogens as one of the drugs of choice for ER+ breast cancers. Anti-estrogens which act by inhibiting the function of ERs include tamoxifen, raloxifen and fulvestrant ${ }^{1}$. Tamoxifen is the most commonly used treatment for patients with ER+ breast cancer and its use as a breast cancer preventative agent and an adjuvant therapy in early cancer has been shown to improve the overall survival ${ }^{2,}{ }^{3}$. Furthermore, the extensive use of tamoxifen has made a significant contribution to the reduction in breast cancer mortality seen over the last two decades.

However, in spite of the obvious benefits of tamoxifen in breast cancer treatment, almost all patients with metastatic breast disease and as many as $40 \%$ of patients receiving adjuvant tamoxifen eventually develop resistance and die from their disease ${ }^{1}$. Hence the issue of tamoxifen resistance has been a major setback in an otherwise successful treatment of ER+ breast cancer.

Though a number of pathways have been proposed and explored, to date there has been no clear mechanism implicated in the development of anti-estrogen resistance. A hitherto unexplored mechanism involves the role of reactive oxygen species (ROS) in the mechanism of tamoxifen resistance. (ROS) comprise of either partially reduced metabolites of oxygen such as superoxide anions $\left(\mathrm{O}_{2}^{-}\right)$; peroxyl radicals (LOO) and hydroxyl radicals $(\mathrm{OH} \cdot)$ or non-radical molecules like hydrogen peroxide $\left(\mathrm{H}_{2} \mathrm{O}_{2}\right)$ and singlet oxygen $\left({ }^{1} \mathrm{O}_{2}\right)$; which have a higher reactivity than molecular oxygen ${ }^{4}$. They are 
products of cellular metabolism which have been shown to induce oxidative stress. An excessive and/or sustained increase in ROS production has been implicated in the pathogenesis of cancer ${ }^{5,6}$. Furthermore, ROS induced oxidative stress has been shown to initiate a number of different responses including cell proliferation and transformation; alteration of intracellular redox state and the oxidative modification of certain signaling proteins resulting in the post translational modification ${ }^{7}$ of their downstream targets. Interestingly, like estrogen, tamoxifen has been shown to induce ROS formation, making it probable that tamoxifen induced ROS generated as a result of prolong tamoxifen treatment of breast cancer patients may play a vital role in the development of tamoxifen resistance.

As protection against oxidative stress, cells have several enzymic and nonenzymic antioxidants or reductants that maintain the intracellular redox environment in a principally reduced state. Typically the enzyme superoxide dismutase (SOD) catalyses the conversion of $\mathrm{O}_{2}^{-}$to $\mathrm{H}_{2} \mathrm{O}_{2}$, and then the $\mathrm{H}_{2} \mathrm{O}_{2}$ generated is degraded to $\mathrm{H}_{2} \mathrm{O}$ by several cellular enzymes, usually Catalase or glutathione peroxidase coupled with glutathione reductase ${ }^{8,9}$. It is however interesting to note that in most cancer tissue the levels/ activity of manganese superoxide dismutase and Catalase have been found to be almost always low. Making a case for the existance of a pro-oxidative environment in cancer cells that may result in an oxidative stress surge and redox signaling culminating in uninhibited cell proliferation. 


\section{Hypothesis and Specific Aims}

We hypothesize that the conversion of breast tumors to a tamoxifen-resistant phenotype is associated with a progressive shift towards a pro-oxidant environment, as a result of chronic oxidative stress. We further postulate that an increase in reactive oxygen species (ROS) levels promotes either the loss of p27 inhibitory function or NRF-1 activation through the inactivation of protein tyrosine phosphates (PTPs) with consequent changes in p27 and/or NRF-1 phosphorylation.

To test this hypothesis, we explored the following Specific Aims:

Aim 1. To investigate whether anti-estrogens prevent estrogen-mediated progression of cell cycle by counteracting estrogen-induced ROS signaling. To further investigate if reducing the oxidative environment of anti-estrogen-resistant breast cancer cells restores the anti-proliferative action of tamoxifen.

Aim 2. To determine mechanisms by which a pro-oxidative state may promote p27 inactivation, and thus cell cycle progression.

Aim 3. To determine mechanisms whereby a pro-oxidative state may promote oxidation of protein tyrosine phosphatase PTEN, NRF-1 activation and cell cycle progression.

Findings of this study will elucidate the roles of the cellular redox state, redox signaling pathways, PTPs and p27 in anti-estrogen resistance, and may lead to new therapeutic strategies to delay or even prevent this important clinical problem. This is a new line of 
research that may lay the groundwork for clinical trials of anti-estrogens plus antioxidantbased drugs for the prevention and treatment of estrogen-dependent breast cancer.

\title{
II. LITERATURE REVIEW:
}

\section{THE ROLE OF REDOX SIGNALING IN THE MOLECULAR MECHANISM OF TAMOXIFEN REISTANCE IN BREAST CANCER TREATMENT}

\begin{abstract}
Anti-estrogens are one of the classes of drugs used to treat ER+ breast cancer. Since their discovery they have been the drugs of choice in breast cancer treatment; prevention and adjuvant therapy for early breast cancer cases. Although anti-estrogens have been beneficial to a large number of patients, unfortunately about $40 \%$ of breast cancer patients and a majority of patients with metastatic breast disease who were initially responsive to the drugs will relapse and die of the disease. In spite of the current breakthrough in our knowledge of the molecular mechanisms that contribute to resistance, antiestrogen resistance remains a major setback in the treatment of ER+ breast cancer. In this review we examine the previously unexplored role of reactive oxygen species (ROS) and redox signaling in the molecular mechanism that contribute to breast cancer resistance to anti-estrogens.
\end{abstract}

\section{Introduction}

In the majority of invasive breast tumors estrogen receptor alpha (ER $\alpha)$ is often upregulated while ER $\beta$ is down-regulated. This finding is the basis for the therapeutic use of 
antiestrogens, which are drugs that disrupt the actions of estrogen and ER $\alpha^{1}$. The types of antiestrogens used include those that inhibit the function of estrogen receptors such as tamoxifen, raloxifene, and ICI 182,780 (fulvestrant), or the aromatase inhibitors such as letrozole and exemestane which block the conversion of androgens into biologically active estrogens.Over the years the successful use of these groups of drugs has been plagued by the emergence of drug resistance, which to date remains a major problem in the treatment of breast cancer.

Herein, we reviewed the role of estrogen and its receptors in the development of breast cancer and the function of tamoxifen as an antiestrogen. We also examined the role of reactive oxygen species (ROS) as signaling molecules and how they may induce antiestrogen resistance by altering the post-translational status of certain signaling proteins which are key players in the cell cycle.

\section{An overview of Estrogen and ER action}

The human breast like that of other mammalian species contains both epithelial and mesenchymal components and a vast majority of malignant tumors are epithelial in origin $^{1}$.

In normal breast cells, estrogen and estrogen receptors are critical regulators which enable the mammary epithelial cells to undergo proliferation, differentiation, apoptosis and remodeling in the course of the mammalian reproductive lifespan ${ }^{1,10,11}$. 
Studies have shown that estrogens initiate different growth responses in tissues depending on the cell type, the dose and the timing of exposure ${ }^{12}$. Moreover, it is now generally accepted that, in addition to its role in the promotion of breast tumors, estrogen also supports the growth of pre-neoplastic and malignant cells through ER-mediated signaling pathways ${ }^{13}$.

The conventional model of estrogen action is based on its binding to $E R \alpha / \beta$ receptors, which initiates transcription either directly by binding to estrogen response elements (EREs) in the promoter region of target genes or indirectly through the phosphorylation of signaling proteins involved in cell cycle progression ${ }^{14,15}$. Overall, estrogen regulates the expression of many genes important for normal cell physiology and growth of some breast tumors ${ }^{16}$.

Both experimental and epidemiologic data suggest that estrogen plays a significant role in carcinogenesis $^{17,15}$. In malignant breast tissue, the action of estrogen and its steroid receptors is dysregulated, resulting in a shift to proliferation without differentiation and apoptosis, and an increase in the percentage of epithelial cells expressing ER $\alpha$. Additionally, cell proliferation makes a change from paracrine to autocrine growth ${ }^{18}$. It is noteworthy that the risk of breast cancer is, in part, due to the duration of proliferation without differentiation. 


\section{Estrogen Receptors (ER)}

Normal human breast cells contain two types of E2 receptors, namely ER $\alpha$ and ER $\beta$, which are the products of separate genes. ER $\alpha$ is expressed in $15-30 \%$ of the luminal epithelial cells (so called estrogen receptor positive cells) while ER $\beta$ is more widely

expressed in the mammary tissue ${ }^{1 ; 19,20} . \mathrm{ER} \beta$ is co-expressed with ER $\alpha$ in the luminal epithelial cells, but can also be found in the myoepithelial cells as well as in the stromal cells. In the normal luminal epithelial breast cells, estrogen-dependent proliferation occurs in a paracrine manner with ER $\alpha$ containing cells producing growth factors that induce proliferation in adjacent estrogen-negative cells.

Deletion of both ER $\alpha$ and ER $\beta$ genes has revealed the significance of E2 for normal female sex organ development and function ${ }^{20 ; 21}$. Both in vivo and in vitro studies in mammals have postulated that E2 plays a considerable role in the maintenance of bone ${ }^{22}$, vascular integrity, and brain function. Estrogen has also been shown to be a significant growth and survival factor for human breast cancer cells ${ }^{23,24}$. ERs act principally as nuclear transcription factors, an event that is enhanced by ligand binding. Though a separate pool of receptors for E2 in the cytoplasm and plasma membrane have been identified, the mechanisms of action and cellular functions of these proteins are just beginning to be unraveled.

\section{Estrogen Receptors: Nuclear/genomic pathway}

The 'genomic action' of E2 occurs after a time-lag of at least $2 \mathrm{~h}$ following E2 stimulation. This action accounts for some hormone functions in physiological and 
pathological situations ${ }^{25,26}$. The nuclear ER contains domains lettered A through F, with activation function (AF)-1 (ligand independent) and AF-2 (ligand dependent) facilitating the transactivation of target genes ${ }^{27}$.

In the so called ligand dependent pathway, ER functions in the nucleus as a transcriptional regulator of specific genes. The receptor protein has a ligand-binding domain (AF-2), several transcription activation domains, and a DNA-binding domain that interacts with specific regions in the promoter of target genes, including sites known as estrogen-responsive elements (ERE) ${ }^{28-30}$. The binding of estrogen to ER induces phosphorylation of the receptor, alters its conformation, and triggers receptor dimerization.

The ER protein in the nucleus can also modify transcription of genes through proteinprotein interactions. In this way, ER can function much like a coactivator protein itself by binding to other transcription factors and recruiting acetyltransferases to complexes bound to activator protein or SP-1 sites on $\mathrm{DNA}^{31}$. This is how estrogen helps to regulate genes encoding proteins such as cyclin D1, insulin-like growth factor I receptor (IGF-IR), and collagenase. ER has also been to be able to decrease the expression of many genes ${ }^{32}$.

In the ligand-independent pathway, the estrogen receptor translocates to the nuclear membrane from the cytosol and can activate transcription in a ligand-independent fashion $^{33}$. These transcriptional activities of ER have been called its classical or genomic 
activity. From a functional perspective, a more appropriate term is nuclear-initiated steroid signaling.

\section{Membrane-initiated Estrogen signaling}

In contrast to the nuclear effects, ER functions that can occur very rapidly in the cell before new gene transcription takes place have been identified. This membrane-initiated steroid signaling could occur outside the nucleus or even in the cell membrane ${ }^{34}$. A number of studies based on endothelial and breast cancer cells have been able to show that a small group of ER is positioned outside the nucleus in the cytoplasm or bound to the plasma membrane ${ }^{35,36} 37,38$. It is thought that the presence of a membrane-bound ER may explain the previously identified short-term effects of estrogen (occurring within minutes) in cultured cells ${ }^{39,40}$. Further investigations have indicated that E2 rapidly activates signaling, such as calcium flux ${ }^{41}$ phospholipase $\mathrm{C}$ activation ${ }^{42}$ and inositol trisphosphate (IP3) generation. Most studies suggest that these actions necessitates E2 binding to ERs. In neural cells, ERs can activate protein kinase $\mathrm{C}$ and protein kinase A. They can also uncouple opioidergic and gabanergic receptors from their effector signaling molecules ${ }^{40}$. These signaling events are likely to be as a result of E2 activation of G proteins. Therefore, ERs appear to be part of the large family of G-protein-coupled receptors (GPCR). After several G proteins are activated, E2-ER can then trigger signaling cascades that terminate in a cell biological function. 


\section{Antiestrogen (Tamoxifen) Action}

Tamoxifen belongs to a class of therapeutic agents called the selective estrogen receptor modulators (SERMs). These drug function as estrogen receptor (ER) antagonists in breast tissue and as ER agonists in the endometrium, heart and bones ${ }^{43}$. 4-hydroxy-tamoxifen is an active metabolite of tamoxifen, which has been shown to compete for binding with natural estrogen to the ER $\alpha$ with high affinity ${ }^{44,45}$.

Subsequent to the antagonist binding to $\mathrm{ER} \alpha$, a different 3-dimensional structure is elicited in the receptor, which renders it unable to enhance specific gene expression. Therefore antiestrogens interrupt the estrogen-induced signals, which can result in the inhibition of cell proliferation, tumor growth arrest, and induction of apoptosis ${ }^{46 ; 47,48}$.

In vitro tamoxifen has been shown to induce G1 phase cell cycle arrest in ER-positive breast cancer cells exposed to estrogens. ${ }^{1 ; 49,50 ; 51}$ creating an avenue by which genes that control cell cycle progression could significantly impact drug sensitivity and resistance. Furthermore, tamoxifen has the capacity to indirectly decrease levels of cyclin D $1^{52}$.

In vivo, tamoxifen inhibits estrogen-stimulated growth of MCF7 xenografts in mice and prevents development of breast cancer in the NMU and DMBA rodent models ${ }^{53,54}$. Similar to estrogens, tamoxifen increases the expression of IGF-I and vascular endothelial cell growth factor in the uterus. ${ }^{55,56}$ In clinical specimens acquired sequentially from patients with breast cancer, administration of tamoxifen has been 
shown to reduce proliferation, upregulate ER expression, downregulate TGF $\alpha$ and induce stromal TGF $\beta 1^{57-60}$.

Other classes of therapeutic agents are the selective estrogen receptor down regulators (SERDs) and aromatase inhibitors (AI). SERDs include ICI182780 (Fulvestrant), which is a pure estrogen antagonist with a 100-fold greater affinity for ER than tamoxifen. By binding ER it inhibits receptor dimerization and abrogates estrogen signaling ${ }^{17}$. Aromatase inhibitors are a second line therapy for post-menopausal patients who have progressed after tamoxifen treatment. They act by inhibiting the action of aromatase which is an enzyme necessary for the conversion of androgens to estrogens.

It is interesting to note that the majority of tumors that develop resistance over time continue to express $\mathrm{ER} \alpha^{10 ; 11}$. Furthermore, many of the tamoxifen-resistant tumors still respond to fulvestrant and AIs, indicating that estrogen remains an important regulator of tumor growth under these circumstances ${ }^{10}$. These data provide support for the idea that endocrine targeted therapies can lead to the activation of novel signaling pathways that evade the effects of antiestrogens.

\section{Redox signaling}

Redox Signaling is process whereby activated or free radicals and reactive oxygen species act as messengers in the biological system. It involves a vital and continuous process by which human cells communicate with each other and carry out essential functions in the body. Redox signaling often entails oxidation-reduction specific reactions. 
Unlike signal transduction which usually involves both reversible and irreversible modifications of second messengers and proteins, redox signaling entails at least one reversible reaction involving the oxidation of a signaling molecule by a reactive species. It may therefore be inferred that the reaction of reactive oxygen or nitrogen species with their target is akin to the on-off signaling associated with phosphorylation than it is to the nonenzymatic lipid peroxidation.

According to Forman et al., ${ }^{61}$ redox signaling occurs when at least one step in a signaling pathway involves one of its components being specifically modified by a reactive species through a reaction that is chemically reversible under physiological conditionsand/or enzymatically catalyzed.

\section{Signaling molecules: Reactive Oxygen or Nitrogen species}

Both reactive oxygen and nitrogen species are known redox signaling molecules.

Reactive nitrogen species (RNS) are molecules having nitrogen atoms, which because of their chemistry, are regarded as being highly reactive towards other cellular components. These molecules may or may not have unpaired electrons. Examples of RNS include radicals like Nitric Oxide (NO), Nitrogen dioxide $\left(\mathrm{NO}_{2}\right)^{\prime}$ and non rasicals like Peroxynitrite $\left(\mathrm{ONOO}^{-}\right)$. On the other hand, Reactive oxygen species (ROS) constitutes either partially reduced metabolites of oxygen such as superoxide anions $\left(\mathrm{O}_{2}^{-{ }^{-}}\right)$; peroxyl radicals (LOO) and hydroxyl radicals $(\mathrm{OH} \cdot)$ or non-radical molecules like hydrogen peroxide $\left(\mathrm{H}_{2} \mathrm{O}_{2}\right)$ and singlet oxygen $\left({ }^{1} \mathrm{O}_{2}\right)$; which have a higher reactivity than molecular 
oxygen. ROS are by-products of normal cellular aerobic metabolism and the exposure of cells to certain forms of stress results in an increase in the level of ROS generated. It is note worthy that high level of reactive oxygen species are injurious to cells because of their tendency to react with a number of intracellular targets, such as proteins, lipids, and DNA. Conversely, quite a number of studies have shown that reactive oxygen species posses a variety of physiologic functions at low concentrations. These functions include but are not limited to: the regulation of gene transcription ${ }^{62}$, signal transduction pathways ${ }^{63-66}$ mitosis $^{67}$, apoptosis ${ }^{67,68}$, and senescence ${ }^{68,69}$. Additionally, it has been shown that the stimulated production of oxidants plays a vital role in the mitogenic response to many growth factors ${ }^{63,66,70}$ For example, ROS have been shown to play a vital role in cell growth mediated by $17 \beta$-estradiol (E2), ${ }^{71}$ peptide growth factors and cytokines including PDGF ${ }^{66}$, vascular endothelial growth factor, insulin, and tumor necrosis factor ${ }^{72}$.

Regarding their role as signaling molecules, some reactive oxygen species such as $\mathrm{H}_{2} \mathrm{O}_{2}$, are considered key signaling molecules, while others appear to be particularly harmful to living systems ${ }^{73}$. In higher organisms, low to moderate concentrations of NO and ROS are utilized as signaling molecules for other normal cellular functions like: their physiological roles in the cellular responses to oxygenation, as in the defense against infectious agents; the initiation of a number of cellular signaling systems and the induction of a mitogenic response ${ }^{72,74,75}$. Furthermore, exposure to a variety of nonphysiologically significant concentrations of ROS or RNS that induce oxidative stress but do not kill cells can stimulate responses such as repair, adaptation, or transformation ${ }^{76}$. 
On the other hand, excessive and/or sustained increase in ROS production has been implicated in the pathogenesis of cancer ${ }^{5,5,6}$. as well as other metabolic diseases like diabetes mellitus $^{72}$. Tumor cells have been shown to have a high and persistent oxidative stress ${ }^{77}$. Free radicals are involved in initiation ${ }^{78}$ as well as promotion/ progression stages of tumorigenesis ${ }^{79,80}$ while inhibitors and scavengers of ROS inhibit these stages of tumor development ${ }^{81,82}$.

Based on work done on the release of ROS by non phagocytic cells, and on cells where ROS have no apparent role, ROS has been shown to be key signaling molecules, even though their exact mode of action was relatively unknown. Currently several studies have shown the ability of ROS to induce necrosis at high concentrations, as well as its role in the induction/inhibition of cell proliferation, and in the activation/inhibition of $\operatorname{apoptosis}^{83,84}$.

\section{Sources of reactive oxygen species}

ROS (usually $\mathrm{O}_{2}^{-\bullet}$ ) can be generated intracellularly by a number of enzymes including NADPH oxidase which upon stimulation undergo a respiratory burst, with the release of superoxide into the phagosome ${ }^{85,86}$ the endoplasmic reticulum which is another site of

electron transport, where $\mathrm{O}_{2}^{-}$is generated by the leakage of electrons from NADPH cytochrome $\mathrm{P} 450$ reductase ${ }^{87}$ cytosolic oxidases; xanthine oxidase and lipoxygenase, and the mitochondrion. In the mitochondria, reactive oxygen species like $\mathrm{O}_{2}{ }^{-}$and $\mathrm{H}_{2} \mathrm{O}_{2}$ are often generated as by-products of electron transfer reactions that occur during the operation of the mitochondrial electron transport chain. ROS is generated in the 
mitochondrial electron transport chain as a result of "leakage" 88 of electrons from electron carriers that are passed directly to oxygen, reducing it to $\mathrm{O}_{2}{ }^{{ }^{-}}$. An evidence of this mode of ROS generation is substantiated by the fact that the mitochondria contain their own superoxide dismutase, an inducible $\mathrm{Mn}^{2+}$-dependent enzyme ${ }^{89}$, for rapid elimination of such reactive species and from a study by Felty et al. ${ }^{90}$ which identified the mitochondrion as a major source of estrogen-induced ROS in breast cancer cells.

ROS is also generated by the metabolism of arachidonic acid by the enzymes cyclooxygenases and lipoxygenases. Prostaglandin $\mathrm{H}$ synthase is a major enzyme in the biosynthesis of prostaglandins, prostacyclins, and thromboxanes. Prostaglandin $\mathrm{H}$ synthase possesses both cyclooxygenase and hydroperoxidase activity ${ }^{91}$, hence it has the capacity to generate ROS as oxidizing equivalents via side-chain reactions that are dependent upon the presence of a suitable reducing substrate such as NADH or NADPH .

Nitric oxide (NO*) is generated from the conversion of the amino acid 1-arginine to 1citrulline by NOS. NO* is an important reactive species containing both nitrogen and oxygen. Production of NO* by neutrophils is well documented, but there are important interspecies differences in the amount of $\mathrm{NO}^{*}$ produced: rodent neutrophils produce substantially more ROS than human cells ${ }^{92 ; 93}$.

\section{7 $\beta$-estradiol (Estrogen) induces ROS formation}

Presently there are several postulates that E2-induced mitochondrial ROS is involved in the growth and proliferation of estrogen-dependent cells. Felty et al. ${ }^{94}$ reported that 
physiological concentrations of E2 stimulate a rapid generation of intracellular ROS and intracellular ROS have been implicated in the promotion of rapid cell cycle activity in neoplastic cells.

One attribute of rapidly dividing cancer cells is their ability to generate significant quantities of intracellular ROS. Studies have shown that estrogen-induced stimulation of both MCF-7 and macrophage cells is partly due to the effect of $\operatorname{ROS}^{95,96}$. In an unpublished data by Singh et al., it was observed that scavengers of ROS such as $N$ acetylcysteine, ebselen, and catalase inhibited the estrogen-induced growth of MCF-7 cells, lending credence to the proposed role of ROS as an autocrine growth signal in estrogen-induced cell proliferation ${ }^{97}$. Based on a study by Taylor et al. ${ }^{98}$, which established that oxidative stress modifies mitochondrial matrix protein thiols, Felty and Roy ${ }^{97}$ extrapolated that an estrogen-mediated cell growth through mitochondrialgenerated ROS signaling molecules may exist. This was based on the reasoning that since exposure to estrogen can generate mitochondrial ROS, the oxidation of thiols in response to estrogen converts the oxidative stress to a change in protein function that is involved in cell growth.

In a study of E2-induced ROS generation in MCF-7 and other cells, the measurable events occurred earlier than a regular ER-mediated genomic action. This lead to the belief that E2-stimulated ROS production does not depend solely on the presence of the ER in breast cancer cells. Further more, because the ER-negative cell line MDA-MB 468 upon E2 stimulation was able to produce ROS equal in amount to that of ER-positive cell lines 
such as MCF7, T47D, and ZR75, it was inferred that, ROS formation upon E2 exposure might explain oxidative damage to hormone-dependent tumors and ensuing genetic alterations ${ }^{99,100}$. A few studies have also revealed that E2-induced production of ROS also provides systematic support for the generation of mutations by physiological concentrations of estrogens ${ }^{101,102}$.

In 2006, Felty ${ }^{103}$ showed that estrogen exposure of human umblical vein and endothelial cells (HUVECs) stimulated a rapid production of intracellular ROS that is involved in signaling endothelial cell growth. He also showed that the early E2 signaling did not require ER-mediated genomic signaling, because E2-induced growth could be inhibited by antioxidants. The functional outcomes of E2-induced ROS formation include an increase in phosphorylation of the signaling proteins C-jun and CREB, as well as the activation of the binding of three oxidant-sensitive transcription factors AP-1, CREB, and possibly nuclear respiratory factor $1(\mathrm{NRF}-1)^{90}$.

Additional findings by Felty et al. suggest that E2-induced mitochondrial ROS modulate G1 to S transition and some of the early G1 genes through a nongenomic, ERindependent signaling pathway resulting in the conclusion that estrogen-induced mitochondrial oxidants control the early stage of cell cycle progression, which could provides the basis for the discovery of novel antioxidant-based drugs or antioxidant gene therapies for the prevention and treatment of estrogen-dependent breast cancer ${ }^{104}$. 


\section{Tamoxifen induces ROS formation}

In addition to its role in inhibiting the growth of ER-positive breast cancer cells through its antiestrogenic properties ${ }^{105}$, tamoxifen also appears to have effects on many ERnegative cancer cells ${ }^{106-109}$. Though the mechanism of this action is not known, as in the case of E2, studies have found the effect of tamoxifen on ER-negative cells to be related to its non-genomic actions.

It has been reported that tamoxifen-induced apoptosis in ER-negative HepG2 human hepatoma cells is mediated by increased intracellular $\mathrm{Ca} 2+{ }^{110}$ and a consequent generation of $\operatorname{ROS}^{111}$. In the study by Lee et al. ${ }^{111}$, ROS appeared to be a downstream signal of elevated intracellular $\mathrm{Ca} 2+$, given that their generation was temporally preceded by elevation of intracellular $\mathrm{Ca} 2+$ within a time frame, and completely inhibited by intracellular and extracellular Ca2+ chelating agents. Another study by Kallio et al ${ }^{112}$ showed that at high doses tamoxifen was able to induce apoptosis through the production of ROS in MCF 7 cells.

Tamoxifen-induced ROS generation has been shown to be produced by membrane bound NADPH oxidase ${ }^{113}$ and not to the activation of enzymes like microsomal enzyme, cytochrome P-450, and numerous catalytic cytosolic enzymes, including cyclooxygenase. The is because ROS production was not altered by treatment with specific inhibitors of these enzymes $^{111}$. NADPH oxidase has also been functionally active in nonphagocytic cells, including endothelial cells ${ }^{114}$, vascular smooth muscle cells, ${ }^{115}$ neuroepithelial bodies of the lung ${ }^{116}$ and type I cells of the carotid body ${ }^{117}$. The components of the 
NADPH oxidase have been expressed in HepG2 cells ${ }^{118,119}$ and the enzyme appears to be a major source of ROS produced by hypoxia ${ }^{118}$. Lee et al ${ }^{111}$. also reported that the NADPH oxidase acts as a major site of the tamoxifen-induced ROS production.

\section{Tamoxifen as a scavenger of ROS}

Several studies including a study by Kuo et al ${ }^{120}$ have shown that 4-OHT (an active metabolite of Tamoxifen) possesses a potent superoxide anion radical-scavenging tendency. The presence of phenolic groups in tamoxifen, (much like raloxifen and E2) confers its antioxidant action chiefly because phenolic structures have the capacity to bind iron, in addition to reducing peroxyl or alkoxyl radicals ${ }^{121}$. In addition, several studies ${ }^{239 ; 122,123 ; 124 ; 125}$ including one by Arteaga et al. ${ }^{126,127}$ have shown that tamoxifen is a scavenger of ROS.

\section{The role of ROS in oxidative stress and redox signaling}

The harmful effect of free reactive oxygen and/or nitrogen species resulting in possible

biological damage is called oxidative stress and nitrosative stress respectively ${ }^{128-130}$. Oxidative and nitrosative stress occur in biological systems following an over production of ROS/RNS as well as an accompanying insufficiency of enzymatic and non-enzymatic antioxidants. Simply put, oxidative stress refers to a disturbance in the balance between pro-oxidant/antioxidant reactions in living organisms. As mentioned previously in this review, excess ROS can damage cellular lipids, proteins, or DNA by hindering their natural function. Hence it comes as no surprise that oxidative stress has been implicated in a number of human diseases as well as in the ageing process ${ }^{131}$. 
Redox regulation, on the other hand, is a very important system responsible for the fairly fragile balance between the beneficial and the harmful effects of ROS/RNS. According to Droge $^{72}$, the redox regulation process protects living organisms from a variety of oxidative stresses and maintains the so-called "redox homeostasis" by controlling the redox status in the living system ${ }^{132}$.

Redox balance, which is the ratio between oxidizing and reducing species within the cell, plays a significant role in the regulation of signaling pathways, including kinase and phosphatase activity as well as gene expression through regulation of the function of transcription factors $7,133,134,134$

As protection against oxidative radical stress, cells have several enzymic and nonenzymic anti-oxidants or reductants that maintain the intracellular redox environment in an especially reduced state. Typically the enzyme superoxide dismutase (SOD) catalyses the conversion of $\mathrm{O}_{2}{ }^{-}$to $\mathrm{H}_{2} \mathrm{O}_{2}$, and then the $\mathrm{H}_{2} \mathrm{O}_{2}$ generated is degraded to $\mathrm{H}_{2} \mathrm{O}$ by several cellular enzymes, usually catalase or glutathione peroxidase coupled with glutathione reductase $^{135,136}$ (see eqn 1).

$$
\mathrm{O}_{2}+\mathrm{e}^{-} \rightarrow \mathrm{O}_{2}^{-} \stackrel{\text { SOD }}{\longrightarrow} \underset{\text { GSH peroxidase }}{\mathrm{H}_{2} \mathrm{O}_{2}} \stackrel{\text { Catalase }}{\longrightarrow} \mathrm{H}_{2} \mathrm{O} \text { (eqn1) }
$$

Other relevant scavengers include thioredoxin coupled with thioredoxin reductase, and glutaredoxin, which uses GSH as a substrate. GSH plays a central role in maintaining redox homeostasis. The GSH to oxidized glutathione ratio (2GSH/GSSG) provides an estimate of cellular redox buffering ability ${ }^{137}$. Forman et al. ${ }^{138}$ have argued that in 
contrast to oxidative stress which is induced as a response to damaged molecules, redox signaling always involves responses that are specific to oxidation reduction reactions.

Oxidative stress often initiates a number of varied responses ranging from cell proliferation and transformation to apoptosis and senescence. The type of effect induced depends on the types and amounts of ROS and reactive nitrogen species (RNS) that are generated, the duration of the oxidative burst, the cellular antioxidant defense systems, and the cellular context in which oxidative stress occurs. For example, low concentration exposure of cells to hydrogen peroxide $\left(\mathrm{H}_{2} \mathrm{O}_{2}\right)$ have been shown to mediate plateletderived growth factor (PDGF)-induced vascular smooth muscle proliferation ${ }^{139}$, whereas moderate concentrations of $\mathrm{H}_{2} \mathrm{O}_{2}$ induce growth arrest while high concentrations induce apoptosis and/or necrosis ${ }^{140}$. Enzymes that are involved in oxidant generation or oxidant scavenging are also critically involved in the regulation of cell growth ${ }^{141-144}$. It has also been documented in several biochemical studies that, in most cancer tissue the levels/ activity of manganese superoxide dismutase and catalase are almost always low while that of copper, zinc superoxide dismutase is usually low. Conversely, the activity of glutathione peroxidase in tumor tissue is variable if measured with biochemical methods using tissue homogenates ${ }^{145-148}$. These findings show an association between low antioxidant levels vis a viz oxidative stress and cancer.

\section{Chemistry of ROS}

Presently, there are two main models of ROS signaling namely: (i) alteration of intracellular redox state and (ii) oxidative modification of proteins ${ }^{7}$. In the alteration of 
intracellular redox state, the cytosol is usually maintained in strong reducing conditions often achieved by the redox balancing action of intracellular thiols like glutathione (GSH) and thioredoxin (TRX).

Studies have shown that depending on their local environment, thiolates $\left(\mathrm{S}^{-}\right)$react with $\mathrm{H}_{2} \mathrm{O}_{2}$ a lot faster than thiols $(\mathrm{SH})^{149}$. It has also been established that in the active sites of proteins like TRX and Prx one cysteine exists in the thiolate form making it more amenable to reacting with $\mathrm{H}_{2} \mathrm{O}_{2}$. In the following redox reactions involving $\mathrm{H}_{2} \mathrm{O}_{2}$ and a thiolate $\left(\mathrm{RS}^{-}\right)^{61}$ (see fig. 1A), the sulfenate $\left(\mathrm{RSO}^{-}\right)$that is formed then reacts with a thiol to form a disulphide bond (see fig.1B). Then the original thiolate is restored by exchange with another thiolate (see fig 1C).

\section{Oxidative modification of proteins}

ROS can change the structure and function of proteins by modifying certain critical amino acid residues, thereby inducing protein dimerization, and interaction with $\mathrm{Fe}-\mathrm{S}$ moieties or other metal complexes ${ }^{7}$. The most recognized oxidative modifications of critical amino acids within the functional domain of proteins involve cysteine residues. The sulfhydryl group (-SH) of a single cysteine residue may be oxidized to form sulfenic (-SOH), sulfinic $\left(-\mathrm{SO}_{2} \mathrm{H}\right)$, sulfonic $\left(-\mathrm{SO}_{3} \mathrm{H}\right)$, or S-glutathionylated (-SSG) derivatives ${ }^{7,}{ }^{150}$. When the critical cysteine is located within its catalytic domain, an alteration of this nature could vary the enzyme activity ${ }^{151}$. On the other hand, when the critical protein is within the DNA-binding motif of a transcription factor, the ability of the transcription factor to bind DNA is affected ${ }^{152}$. For example, the active site of all but one of the protein 
peroxiredoxin (Prx) contains cysteines out of which one is a thiolate $\left(\mathrm{S}^{-}\right)$. Prx will react with ROS to form sulfenic acid (see fig. 2A). A second thiol then reacts with the sulfenate to form an intramolecular disulphide (see fig 2B). In the third and final step, all but one Prx use TRX to restore the original thiolate (see fig 2C).

\section{Redox signaling and its effect on signaling pathways}

Oxidative and reductive stress can induce redox surges with a resultant change in the thiol status of the proteins. Post-translational modifications of proteins or changes in the thiol status of proteins due to changes in the redox environment of the cell are two of the major pathways for signaling in cells. Characteristically, changes in the cellular redox environment could result in modification of signal transduction, DNA and RNA synthesis, protein synthesis, enzyme activation, as well as regulation of the cell cycle $\mathrm{e}^{153-}$ $155 ; 156 ; 157 ; 137,158,159$.

A number of studies have shown that ROS and RNS have the ability to change or modify several signaling pathways ${ }^{72,160-165,165}$. Among these pathways are the mitogen-activated protein kinases (MAPK), which has been shown to be activated by both exogenous, and receptor stimulated $\mathrm{H}_{2} \mathrm{O}_{2}{ }^{166}$; Protein tyrosine phosphatases (PTPs) and thioredoxin (TRX). Modification of signaling pathways is possible because certain key proteins such as PTPs and TRX contain essential cysteines which serve as targets for ROS and RNS ${ }^{167}$, 168. Transcription factors like AP-1 and NF-kB, and Caspases are considered redox sensitive because it has been biochemically demonstrated that their critical cysteines are 
in the thiolate form accounting for the ease with which they are oxidized and reduced by oxidants and enzymes ${ }^{169-171}$.

The first evidence of reversibility of thiols oxidized by ROS and RNS was demonstrated with PTPs at a time when PTPs were first recognized as important players in signaling. Over the years, redox-mediated regulation of PTPs has been supported by several in vivo studies. The following PTPs are known targets for ROS and RNS, PTP1B, SHP-2, LMW-PTP, PTEN as well as CDC25 $5^{172}$.

\section{ROS induces the oxidative modification of Protein tyrosine phosphatases (PTPs)}

Protein tyrosine phosphatases (PTPs) are important enzymes in the control of cell cycles and signal transduction. They act in conjunction with protein tyrosine kinases to regulate the phosphorylation of protein tyrosine in response to cellular signals ${ }^{173,174}$. Many studies have revealed that PTKs may be directly activated by the inhibition of PTPs by ROS ${ }^{167}$, 175, 176 . Reversible inactivation of PTPs by ROS (especially $\mathrm{H}_{2} \mathrm{O}_{2}$ ) plays an important role in redox control and cell signaling ${ }^{132}$. Based on the work done by Rhee's laboratory, we now know that stimulation of A431 cells with epidermal growth factor (EGF) leads to the generation of $\mathrm{H}_{2} \mathrm{O}_{2}$ and a consequent inhibition of PTP1B ${ }^{70}$. Other biochemical studies also showed that an increase in the production of intracellular oxidants could contribute to enhanced tyrosine phosphorylation-dependent signaling, such as signaling in response to growth factors ${ }^{70 ; 66}$, by transiently stemming the enzymatic activity of members of the PTP family, and promoting a burst of PTK activity ${ }^{177,178}$. However, it is unclear if this phenomenon is the same for every member of the PTP family. 
ROS and the cellular redox state are able to regulate the activity of PTPs. PTPs have a functional motif that contains a constant cysteine residue, which acts as an electron donor in catalysis ${ }^{179,180}$. As a result of its unsually low $\mathrm{pKa}$, the functional cysteine residue is prone to oxidation and thus inactivation. Only oxidations that do not advance beyond sulfenic acid $(\mathrm{S}-\mathrm{OH})$ are reversible ${ }^{181,182}$. A vital requirement for regulating the activity of PTPs (or any regulating molecule) is that the modification be specific and reversible. However, the cysteine sulfenic acid formed at the active site of phosphatases can be oxidized further to non-reversible cysteine-sulfinic acid and cysteine-sulfonic acid, within the cell ${ }^{183}$. This effect is believed to be countered by glutathionylation ${ }^{184}$.

Glutathionylation is a reaction of either cysteine or cysteine sulfenate with GSH within the cell to form a mixed disulfide bond. The formation of a mixed disulfide between PTP1B and GSH (or GSSG) would prevent irreversible oxidation of the active site cysteine and provide for the reversible reduction either chemically or enzymatically. Barrett et al. ${ }^{185}$ have reported that PTP1B is inactivated by the formation of a mixed disulfide with glutathione and that this inactivation is reversed not only by DTT but also more importantly by thioltransferase, a thiol-disulfide oxidoreductase that is specific for glutathionyl mixed disulfide substrates ${ }^{186,187}$ and specifically utilizes GSH as cosubstrate $^{188}$. The glutathionylation occurs on Cys215, the active site cysteine. This mechanism suggests an alternative modification to the redox regulation of cysteine in PTP1B and suggests a possible in vivo mechanism in the regulation of phosphatase 
activity. Also, reversible S-glutathionylation also appears to form the basis for redox regulation of c-Jun DNA binding ${ }^{169}$.

PTP-1B is directly inactivated by ROS-induced reversible oxidation of its catalytic site, Cys215, and this has been proposed as a mechanism for EGF-mediated mitogenic signaling ${ }^{151 ;} 189$. Studies on B lymphocytes reveal that, following B cell receptor activation, the ROS produced by DUOX1 enhance prompt generation of a signal by reversible inhibition of SHP1, which then results in enhanced tyrosine phosphorylation and activation of Lyn kinase ${ }^{190}$. Superoxide radical has been shown to regulate the activity of PTPs (especially PTP1B) very efficiently, again through cysteine residues ${ }^{132}$.

\section{Phosphatase and Tensin Homologue (PTEN) and Reactive Oxygen Species}

The tumor suppressor PTEN (phosphatase and tensed homologue) regulates cell growth, survival and migration by the removal of the 3 '-phosphate of phosphoinositides. It has been reported that the exposure of cells or purified PTEN to $\mathrm{H}_{2} \mathrm{O}_{2}$ resulted in inactivation of PTEN in a time- and $\mathrm{H}_{2} \mathrm{O}_{2}$ concentration-dependent manner ${ }^{167,189,191}$. As with other phosphatases, $\mathrm{H}_{2} \mathrm{O}_{2}$ induces the reversible inactivation of PTEN through oxidation of the essential Cys $124^{167 ;} 192$. This forms cysteine-sulfenic acid, which reacts with the socalled backdoor cysteine (Cys71 substrate) to form a disulfide. The disulfide formed is then further reduced to its active form by thioredoxin (TRX) $)^{193}$.

Though the stimulation of various receptors induces $\mathrm{H}_{2} \mathrm{O}_{2}$ production, Lee et al. ${ }^{194}$ proposed that the receptor-mediated activation of phosphoinositide 3-kinase (PI3K) alone 
does not does not account for the accumulation of 3'-phosphorylated phosphoinositides, and that the simultaneous inactivation of PTEN by $\mathrm{H}_{2} \mathrm{O}_{2}$ produced in response to receptor stimulation might also be essential for this event ${ }^{195}$. A high frequency of PTEN mutations and subsequent loss of function has been reported in several tumor types like endometrial carcinoma, brain, and breast cancer ${ }^{196}$. It is documented the loss of PTEN function results in an increased Akt activity and, subsequently, cell survival ${ }^{197}$. Evidence exists that inactivation of PTEN by oxidation might be a physiological mechanism for regulation of this enzyme, not only by oxidative stress, but by ROS produced in other circumstances such as the stimulation of cells by growth factors ${ }^{198,} 199$.

The cyclin-dependent kinase inhibitor $\mathrm{p} 27^{\mathrm{Kip} 1}$, a target of Akt, has been proposed as a downstream mediator through which PTEN may positively regulate cell cycle progression ${ }^{200}$. In prostate cancer, $16-68 \%$ of the cases show an association between the low grade expression or loss of p27 protein with either adverse or impaired prognosis ${ }^{201-}$ $204 ; 205$

\section{CDC25 Phosphatases and Reactive Oxygen Species}

Cdc25 phosphatases also known as the dual-specificity phosphatases, are key activators of the $\mathrm{CDK} /$ cyclin complex, hence they serve as regulators of normal cell division. There are three isoforms of $\mathrm{Cdc} 25$, namely $\mathrm{Cdc} 25 \mathrm{~A}, \mathrm{Cdc} 25 \mathrm{~B}$, and $\mathrm{Cdc} 25 \mathrm{C}$. These three phosphatases function to dephosphorylate the CDK/cyclin complex on pThr14 and/or pTyr15 residues, counteracting the phosphorylating effect of the Weel and Myt1 kinase. This dephosphorylation prompts the ultimate activation of $\mathrm{CDK} /$ cyclin activity during 
normal cell cycle progression ${ }^{206,207}$. Cdc25A controls both the G1-to-S and G2-to-M transitions, whereas $\mathrm{Cdc} 25 \mathrm{~B}$ and $\mathrm{Cdc} 25 \mathrm{C}$ are regulators of the $\mathrm{G} 2$-to-M transition.

The Cdc25 phosphatases also play an important role in the checkpoint response that prevents CDK/cyclin activation following DNA damage ${ }^{208,209}$. Confirming an important role for the $\mathrm{Cdc} 25$ phosphatases in cancer, $\mathrm{Cdc} 25 \mathrm{~A}$ and $\mathrm{Cdc} 25 \mathrm{~B}$, but not $\mathrm{Cdc} 25 \mathrm{C}$, are over expressed in many different primary human cancers ${ }^{210}$.

Like all other PTPs Cdc25 phosphatases have two cysteine molecules in their functional site. One of the cysteines exists in the very reactive thiolate $\left(\mathrm{S}^{-}\right)$form while the other one exists as a less reactive thiol. The thiolate in Cdc25's functional motif has been shown to be oxidized by low concentrations of ROS resulting in the formation of a reversible cyseine-sulfenic acid (see eqn 13). The resultant sulfenic acid then forms a mixed disulfide bond with the second thiol to prevent further oxidation by ROS to an irreversible sulfinic acid. The reduction of the disulphide bond to the original thiolate is carried out by either TRX or GSH. $\mathrm{H}_{2} \mathrm{O}_{2}$ causes oxidation of the active site cysteine residue in Cdc25- PTP, with a subsequent binding to 14-3-3 proteins for nuclear export and subsequent degradation ${ }^{211 ; 212,213}$. Oxidative stress has also been shown to induce the nuclear export of Cdc25B through protein kinase B/Akt-dependent phosphorylation on Ser353 ${ }^{214}$.

An association between mitogenic signaling and the cell cycle mechanism has been suggested by studies which showed that the tyrosine phosphatase Cdc25A, among others, 
could have an effect on Raf-1, a key component of the MAPK pathway ${ }^{215,216}$. In 1995, Conklin et al. showed that Raf-1, which is known to bind 14-3-3 proteins, appeared to associate with Cdc25A and stimulate its phosphatase activity ${ }^{217}$. Galaktionov et al. ${ }^{218}$ also showed an association between the Cdc25 phosphatase and Raf-1 in somatic mammalian cells and in meiotic frog oocytes. These authors also suggested that activation of the cell cycle by the Ras/Raf-1 pathways might partially be mediated by Cdc25. Another study also showed that dephosphorylation of Raf-1on tyrosine by Cdc25A resulted in a significant decrease in the kinase activity of Raf- $1^{219}$, and consequently of ERK. On the flip side, this implies that inactivation of CDC25A could lead to an increase in the kinase activity of Raf- 1 and thus the phosphorylation and activation of ERK.

Recently, a study by Vogt et al. ${ }^{220}$ showed that overexpression of Cdc25A in whole cells resulted in the dephosphorylation of ERK, which was reversible by an inhibitor of Cdc25A (2-mercaptoethanol)-3-methyl- 1,4-naphthoquinone (compound 5). The high point in this study is that a Cdc25 inhibitor increased phosphorylation and nuclear accumulation of ERK thereby underscoring the proposition that $\mathrm{Cdc} 25 \mathrm{~A}$ regulates the phosphorylation state of ERK. More recently, in addition to showing a physical interaction between Raf- 1 and Cdc25A, Nemoto et al. ${ }^{221}$ were also able to show that the phosphatase Cdc25A regulates Raf-1/MEK/ERK kinase activation in human prostate cancer cells. Additional work done by Wang et al. ${ }^{222}$ suggested that phospho-ERK is possibly another substrate of Cdc25A. Based on the above studies, one can infer that the oxidation (downregulation) of CDC25A by ROS (which renders Cdc25A inactive) may 
also result in the phosphorylation of ERK that could ultimately phosphorylate a number of transcription factors, as well as the CDK inhibitor $\mathrm{p} 27$.

\section{Mitogen Activated Protein Kinase- Phosphatase (MKPs) and Reactive Oxygen Species}

These are dual specificity phosphatases which have the ability to inhibit the mitogen activated protein kinases (MAPKs) in several cell types ${ }^{223-229}$. Like other dual specificity phoshatases, mitogen activated protein kinase phosphatases (MKPs) have recently been added to the redox sensitive phosphatases list. Seth and Rudolf ${ }^{230}$ showed that, like other PTPs, MKPs are able to form cysteine-sulfenic acid upon oxidation by ROS. Unlike other PTPs, however, the sulfenic acid formed does not form a disulfide with proximate cysteine or sulfenyl amide bond species with neighboring residue, but rather utilizes various cysteines distributed in both the N-terminal substrate-binding domain (Cys147 in particular) and the C-terminal catalytic domain (Cys218) to protect its active site from further oxidation.

MAPKs play a central role in mediating intracellular signaling events triggered by mitogens, growth factors, and stress ${ }^{231,232}$. The MAPKs are activated by specific upstream dual specificity kinases (MAPK kinases, MKKs) through phosphorylation on both threonine and tyrosine residues in the TXY motif. Extracellular stimuli activate MAPKs leading to the phosphorylation of an array of cellular substrates and nuclear transcription factors. 
In mammals, three distinct MAPK families have been studied extensively. The extracellular signal-regulated kinase (ERK) family is activated by growth and differentiation factors and by phorbol esters ${ }^{233}$. The c-Jun NH2-terminal kinase (JNK) family (or stress-activated protein kinase (SAPK) and p38 MAPK families are activated by pro-inflammatory cytokines and environmental stress. It is noteworthy that the three aforementioned subgroups of MAPKs have been implicated in both cell growth and cell death, hence the need to tightly regulate these pathways is principal in determining cell fate $^{234}$. Therefore the injurious effect of non-stop activation of MAPK pathways may include excessive production of MAPK-regulated genes, uncontrolled proliferation, and unscheduled cell death $^{235}$.

A number of cellular stimuli that induce ROS production are also capable of activating MAPK pathways concurrently, in multiple cell types. This was established by studies which showed that prevention of ROS accumulation by antioxidants blocks MAPK activation after cell stimulation with cellular stimuli ${ }^{235-237}$. Additionally, it has been documented that direct exposure of cells to exogenous $\mathrm{H}_{2} \mathrm{O}_{2}$, to imitate oxidative stress, resulted in the activation of MAPK pathways ${ }^{238,239}$. Though the mechanism(s) by which ROS can activate the MAPK pathways, is still not well defined and because ROS can change protein structure and function by modifying critical amino acid residues of proteins $^{7,238,239}$, we could therefore infer that the oxidative modification of signaling proteins by ROS may a probable mechanism for the activation and or inactivation of MAPK pathways. 


\section{The Effect of ROS on Transcription Factors}

\section{AP-1 and NFкB}

The tumor progression stage of carcinogenesis has been shown to be modulated by transcription factors such as activator protein-1 (AP-1) and nuclear factor-kappaB $(\mathrm{NF} \kappa \mathrm{B})$. A causal relation has been well documented between neoplastic transformation and transcription factor AP-1 transactivation ${ }^{240-243}$. Infact, a constitutive increase of AP-1 activity has been associated with the malignant conversion of papillomas to carcinomas

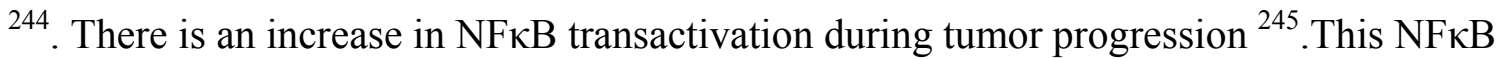
transactivation is also increased by agents that elevate AP-1 activity during tumor progression while its inhibitors also attenuate AP-1 activity ${ }^{246,247}$ suggestive of common upstream signaling cascades that mediate elevated AP-1 in addition to NFאB transactivation during tumor progression.

ROS have been shown to act as activators of transcription factors which modulate their activity either directly or indirectly by activating other signaling cascades. NFאB transactivation is considered redox sensitive because (i) The phosphorylation of its inhibitor I- $\kappa \mathrm{B}$ is mediated by oxidation; and (ii) the Ref/thioredoxin-dependent binding of the p50 subunit to the DNA is controlled by the reduction of an essential cysteine group ${ }^{248}$ (cite article). NFאB activation can be be induced by several activators/oxidants in the absence of any physiological stimulus and is inhibited by a wide range of antioxidants ${ }^{249-}$ ${ }^{251}$. On the other hand AP-1 DNA binding activity has also been shown to be modulated by Ref/thioredoxin-dependent reduction of cysteines in c-Jun and c-Fos ${ }^{252}$. 
Persistently high ROS levels activate redox-sensitive transcription factors, such as nuclear factor-kappaB (NF-kB) and activator protein-1 (AP-1), which may then act as molecular switches that convert normal cells into premalignant cells, with ensuing clonal expansion to form solid tumor ${ }^{253}$. Hence, abnormal activation of NF- $\mathrm{kB}$ and AP-1, which results in the transcriptional activation of genes involved in inflammation, cellular proliferation, and growth, has been implicated in pathophysiology of various malignancies ${ }^{253,254}$.

Mitogen-activated protein kinases (MAPKs) have been shown to modulate transcription factor activities in addition to being part of kinase cascades that serves as transmitters connecting extracellular stimuli to specific transcription factors thus allowing these signals to regulate specific gene expression. Studies have shown that JNKs and p38 MAPK are a part of the stress response pathways activated by cellular stress induced by agents like heat, UV and ionizing radiation and inflammatory cytokines mediating inhibition of cell proliferation or cell death ${ }^{255,256}$. AP-1 activity has been shown to be modulated by MAPKs in response to various stimuli ${ }^{257}$. NFkB activation has been reported to be modulated by MEKK1, a kinase upstream of JNKs ${ }^{258}$ as well as p38

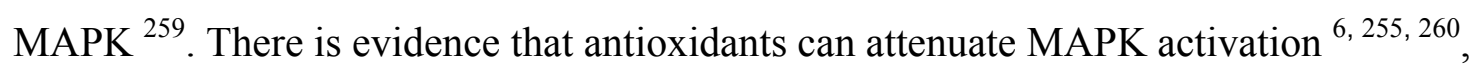
thereby suggesting that MAPK signaling cascades are additional targets affected by ROS levels in cells.

\section{NRF-1}

Nuclear respiratory factor $1(\mathrm{NRF}-1)$ is a protein that encodes genes that code for a phosphorylated nuclear protein with a bZIP domain. The encoded protein forms a homo- 
or heterodimer, which functions as a transcription factor that activates the expression of some key metabolic genes. These key metabolic genes regulate cellular growth and nuclear genes required for respiration, heme biosynthesis, mitochondrial DNA transcription and replication ${ }^{261,262}$ Initially, NRF-1 was described as an activator of cytochrome c expression and afterwards was found to act on many nuclear genes essential for mitochondrial respiratory function ${ }^{263,264}$ such as genes encoding respiratory subunits ${ }^{265}$, the rate-limiting heme biosynthetic enzyme ${ }^{266}$ as well as mtDNA transcription and replication factors ${ }^{267,268}$.

NRF-1 binds to the antioxidant response element (ARE) in the promoters of genes which are involved in response to cellular stress ${ }^{269}$ to induce the expression of phase II detoxifying enzymes and oxidative stress-inducible proteins, like NADPH, quinone oxidoreductase, and glutathione S-transferaseA2 270,271 . Studies have shown that NRF-1's ability to regulate the ARE of stress-related genes and TNF $\alpha$ is based on its interaction with transcription factors such as AP1 proteins (c-Jun, JunB, and JunD) $)^{272,273}$. In addition, NRF-1 has been shown to play an important role in cellular growth and differentiation ${ }^{274,275}$. A biochemical study by Chang et $\mathrm{al}^{276}$. implicated NRF-1 protein with the regulation of neurite outgrowth.

Studies have shown that NRF-1 is phosphorylated both in vivo and in vitro on serine residues within a concise amino-terminal domain ${ }^{277}$. The phosphorylation of these sites in vitro augments NRF-1 DNA binding action, surmising the capacity of such modifications to regulate NRF-1 function. Herzig et al. ${ }^{278}$ showed that the activity of NRF-1 is 
enhanced by phosphorylation, which occurs in cells that have been stimulated with serum. It is assumed that a phosphorylation such as this allows the nuclear transcriptional apparatus to respond both to extracellular signals and intracellular ATP concentrations in controlling the expression of the respiratory chain ${ }^{278}$. The post-transcriptional modification of the N-terminus of NRF-1 has been shown to play an important role in controlling DNA-binding activity ${ }^{277}$. It has been established that $\mathrm{P} / \mathrm{CAF}$, which is a p300/CBP (cAMP response-element-binding protein (CREB)-binding protein)-associated factor, can interact directly with the N-terminal domain of NRF-1 and modify it by acetylation. The ensuing modification significantly stimulates the DNA-binding activity of NRF-1 ${ }^{279}$. A study by Cho et al. ${ }^{280}$ showed that the methylation on the NRF-1 sites may be a means of silencing the Tfam promoter with an ensuing decrease of mitochondrial biogenesis ${ }^{281}$. According to Narayanan et al. ${ }^{282}$ NRF-1 often exists as a complex with Keap1 (inhibitor) but as a result of stress, NRF-1 separates from Keap1 and becomes active.

\section{NRF-1 and $17 \beta$-Estradiol (E2)}

Estrogen increases the transcription of NRF-1 ${ }^{283,284}$. Results of work done by RodríguezCuenca et al. ${ }^{285}$ show that E2 appears to affect the mitochondrial biogenic program in two ways. The first is inhibiting it through the downregulation of NRF-1, gabpa, and tfam mRNA $^{286}$; or second, downregulating PTEN mRNA levels in cell-cultured brown adipocytes, implying an activation of the PI3K-Akt pathway and therefore a mitochondrial recruitment-stimulatory signal. E2 has been shown to inactivate PTEN activity by phosphorylation and, hence, influence PTEN activity, suggesting both a 
chronic and an acute control mechanism of PTEN by estrogens ${ }^{287}$. Felty et al. ${ }^{288}$ showed that E2-induced oxidants increase the transcriptional activity or binding of AP-1, CREB, and NRF-1 to their individual DNA response elements. The study actually showed that at physiological concentrations E2 stimulates a rapid production of intracellular ROS resulting in the phosphorylation of c-jun and CREB as well as increased activity of redox-sensitive transcription factors NRF-1, c-jun, and CREB, which are known to be involved in the regulation of cell cycle genes ${ }^{289}$.

\section{NRF-1 and Cancer}

$\mathrm{Xu}$ et al. ${ }^{290}$ have been able to demonstrate a connection between cancer and NRF-1, based on the result of a study which observed changes in NRF-1LKO (NRF-1 liver knock-out ) livers. The livers were characterized initially by cell death, proliferation, and inflammation, followed by the appearance of dysplastic cells and eventually cancer. The $\mathrm{X}$ gene of hepatitis B virus (HBV) which is one of the chief factors in $\mathrm{HBV}$-induced hepatocarcinogenesis is necessary to achieve a productive HBV replication in vivo. Recently, Tokosumi and others ${ }^{291}$ showed that NRF-1 exclusively binds the 21-bp minimal promoter and contributes to transcription of the $\mathrm{X}$ gene. They also suggested that concurrent activation of the $\mathrm{X}$ gene and mitochondrial genes by NRF-1 may allow the $\mathrm{X}$ protein to target mitochondria most efficiently ${ }^{292}$. A study by Auf dem Keller et al. ${ }^{293}$ showed that NRF-mediated gene expression in keratinocytes is dispensable for wound healing but crucial for skin tumor prevention. 


\section{NRF-1 and cell cycle}

The transition of cells from quiescence $\left(\mathrm{G}_{0}\right)$ to proliferation $(\mathrm{G} 1)$ increases the cellular energy (ATP) demand. The cell responds to this increase in demand for ATP by modulating the activity of the respiratory chain components, and it is the duty of NRF-1 to regulate the expression of a number of genes required for mitochondrial respiratory function $^{264}$.

A recent study demonstrated that NRF-1 activity is enhanced by phosphorylation upon serum-induced proliferation, leading to transcriptional induction of cytochrome $c$, a major component of the respiratory apparatus ${ }^{294}$. The induction of cytochrome $c$ was associated 295 with enhanced energy production by the mitochondria in preparation for entry to the cell cycle.

Results from work done by Herzig et al. ${ }^{296}$ show that NRF-1 functions to induce gene expression and maintain the level of cytochrome $c$ in actively dividing cells. Additionally, the results also suggested the possibility that activated NRF-1 may contribute to the synthesis of other respiratory chain constituents later in the cell cycle. It can therefore be inferred that the phosphorylation of NRF-1 may be a significant regulatory event in the transition from quiescence to active cell division.

Virbasius et al. ${ }^{297}$ showed that NRF-1 sites are found in genes that may be directly involved in cell cycle regulation (like cdc2, RCC1) or are regulated by cell growth (like omithine decarboxylase, DNA polymerase-a, and GADD153). Their study concluded that 
even though the most current and best defined biological role for NRF-1 is in the nuclear control of mitochondrial function, the NRF-1 protein or related proteins having the NRF1 DNA-binding domain may possess the ability to integrate various functions required for cell maintenance, growth, and proliferation. ${ }^{298}$

NRF-1 has been shown to mediate the apoptotic function of $c-m y c$ in a study which also shows that cytochrome $c$ and other nuclear-encoded mitochondrial genes are also regulated by NRF-1 and provides evidence of a link between the induction of NRF-1 target genes and sensitization to apoptosis on serum depletion ${ }^{299}$. The finding by Felty et al. ${ }^{300}$ that E2-induced mitochondrial ROS control the expression of early G1 phase genes (Felty and Roy, unpublished results), imply that E2-induced ROS increase the transcriptional activity or binding of AP-1, CREB, and NRF-1 to their respective DNA response elements responsible for the expression of early cell cycle genes. Based on previous studies (already mentioned in this review) which showed that redox-sensitive transcription factors c-jun, CREB, and NRF-1 regulate cell cycle genes ${ }^{262,301,302}$, Felty et al.'s finding could be a pointer that E2-induced ROS may play a role in cell cycle progression of estrogen-dependent cells ${ }^{303}$.

\section{NRFI and ROS}

A study by Suliman et al. ${ }^{262}$ showed that ROS signaling is necessary for hepatic mitochondrial biogenesis accompanying cell proliferation, which is linked to activation of pro-survival PI3K-Akt pathways. The PI3K-Akt pathway in turn leads to NRF-1 activation and subsequent DNA binding. Furthermore, ROS originating in mitochondria, 
cytoplasm, or outside the cell could activate Akt and promote NRF-1 translocation. Hence, PI3K-Akt activation may regulate both mitochondrial biogenesis and cell proliferation after oxidative stress.

Already mentioned in this review is the fact that cysteine-dependent phosphatases, like PTEN, which are reciprocal regulators of PI3K, are sensitive to inactivation by oxidants. This is substantiated in a recent study by Piantadosi and Suliman ${ }^{304}$, which provided evidence that the stimulation of PI3K by extracellular oxidants activate Akt and promote NRF-1 phosphorylation as well as nuclear translocation. NRF-1 phosphorylation increases its ability to stimulate transcription of Tfam, a downstream nuclear-encoded gene for a mitochondrial protein required for mtDNA transcription and replication.

Based on work done on HeLa cells, Miranda et al. ${ }^{305}$ have been able to show that cells depleted of mitochondrial DNA $\left(\rho^{0}\right)$ have an increased amount of intracellular ROS, and that under these conditions, NRF-1 and Tfam are up regulated, further supporting the postulated role of ROS in mitochondrial signaling to the nucleus. NRF-1 has also been found to play a role in the regulation of genes involved in glutathione synthesis, therefore signifying a basis for an equally low GSH concentration and reduced stress response in a study which also found that interference with the NRF-1 gene results in hypersensitivity of fibroblasts to the noxious effects of various oxidizing agents ${ }^{306}$. Work done by Chen et al. ${ }^{307}$ showed that NRF-1 may be required to protect fetal liver cells from endogenous TNF-induced apoptosis. The study concluded that NRF-1 plays an important role in maintaining redox balance in the fetal liver cells signifying a cell-specific and 
developmental stage-specific function of NRF-1 in protecting liver cells from apoptosis during development.

\section{Cell Cycle}

\section{Cell cycle control}

Simply put, a cell cycle refers to a programmed life cycle of a dividing cell. The process of cell-cycle transition can be divided into four phases: the G1 phase, where mRNA and proteins are synthesized in preparation for DNA synthesis; the S phase where DNA synthesis occurs; the G2 phase, where mRNA is synthesized in preparation for the fourth phase, mitosis (M phase). Quiescent cells are found in the $\mathrm{G}_{0}$ phase and exhibit minimal mRNA and protein synthesis. Stimulation of quiescent cells (G0) results in their entry into the G1 phase which in turn induces a number of proteins that regulate and control cell growth and proliferation ${ }^{229 ; 308}$.

In addition to the four cell cycle phases, there are two main checkpoints that regulate cellcycle progression. The G1/S checkpoint prevents the replication of damaged DNA. This checkpoint is regulated by a balance between growth-stimulating and growth-inhibitory responses. The second checkpoint, which is $\mathrm{G} 1 / \mathrm{S}$ to $\mathrm{G} 2 / \mathrm{M}$ checkpoints control the sequence and timing of cell-cycle transitions, enabling the assimilation of cell division with environmental stimuli as well as the monitoring of DNA damage to maintain genomic integrity. An additional spindle assembly checkpoint functions to delay mitosis until the mitotic spindle is correctly formed ${ }^{309}$. 
The cell cycle process is controlled by the following proteins: The cyclins, namely cyclins A, D, and E; the cyclin dependent kinases CDK2, 4, and 6; the cyclin kinase inhibitors (CKIs), namely p16 $6^{\mathrm{INK} 4 \mathrm{a}}(\mathrm{p} 16), \mathrm{p} 21^{\mathrm{CIP} 1 / \mathrm{WAF} 1}(\mathrm{p} 21)$, and $\mathrm{p} 27$; and other negative regulators such as the retinoblastoma protein $(\mathrm{Rb})$ and $\mathrm{p} 53$, which regulate the effects of both CKI p21 and cyclin A protein ${ }^{310}$. During the G1phase, cyclins D1 and E are rapidly synthesized and bind to CDK4 and CDK2, respectively. The resulting cyclinD-CDK4/6 complex then phoshorylates the retinoblastoma protein $(\mathrm{Rb})$. Phosphorylation of $\mathrm{Rb}$ releases E2F which mediates gene expression and the induction and the formation of cyclin E- CDK2 complex.

The cyclin E- CDK2 complex phosphorylates a broad variety of proteins, including Rb with a consequent release of E2F, which promotes cell-cycle progression to late G1, leading to the induction and formation of the cyclin $\mathrm{A} / \mathrm{CDK} 2$ complex.

The cyclin A/CDK2 complex functions to advance cell-cycle progression through the G1/S phase, into S, as well as late $\mathrm{S}$ and $\mathrm{S} / \mathrm{G} 2$ interphase (cyclin $\mathrm{A} / \mathrm{CDK} 1$ ). Cyclin A/CDK1 collaborates with Cyclin B/CDK1 to regulate G2 to M phase transition. In its phosphorylated state, cyclin B complex is inactive and requires dephosphorylation on Tyr 15 by $\mathrm{CDC} 25$ to activate it. The active cyclin B complex promotes cell division (M phase $)^{229}$.

The active cyclin D complex is inhibited by CDK inhibitor p16 to induce early G1 arrest and prevent the phosphorylation of $\mathrm{Rb}$. It has also been shown that $\bullet \mathrm{NO}$ has the potential 
to induce p21, leading to the inhibition of the action of cyclin E complex. Proliferating cell nuclear antigen (PCNA), a cofactor for DNA polymerase is negatively regulated by p2 $1^{311}$. Inhibition of CDK2 activity by p27 can prevent the phosphorylation of transcription factors critical for entry into the $\mathrm{S}$ phase ${ }^{312}$. In G2, p53 can induce late G2 arrest (inhibition of active cyclin B action) or mediate early G2 arrest via p21 inhibition of $\operatorname{Cdc} 25$.

\section{The role of p27 in cell cycle control}

The CDK inhibitor p27 has a negative effect on the activity of CDK2-cyclin complexes during G1 phase and CDK1 (Cdc2) complexes during G2 phase. In breast cancer, cyclins D1 and $\mathrm{E}$, in addition to the cyclin-dependent kinase inhibitors p21 and p27, play very important roles in cell-cycle control and as potential oncogenes or tumor suppressor genes. Reduced expression of $\mathrm{p} 27$ has been associated with the poor survival of cancer patients $^{313}$.

In breast cancer cells, $\mathrm{CDK}$ inhibitors are regulated following mitogenic stimuli such as activation of receptor tyrosine kinases and steroid hormone receptors. Their deregulation frequently impacts on breast cancer outcome, including response to therapy ${ }^{314}$. The expression of p27 is regulated through transcriptional and translational control mechanisms, by modulation of both protein stability and changes in subcellular localization.

According to Medema et al. ${ }^{315}$, even though the transcription of the p27 gene is regulated by factors like AFX-like Forkhead transcription factors, the abundance of p27 during the 
cell cycle is mostly mediated post-transcriptionally. As cells exit quiescence and progress into $\mathrm{S}$ phase, the levels of $\mathrm{p} 27$ protein decline as a result of decreased translation of p27 mRNA and targeted proteolysis ${ }^{316}$.

In the G1 and S phase, degradation of p27 is regulated by two RING-finger E3 ubiquitin ligase-containing complexes with contrasting subcellular locations. These complexes respectively ubiquitylate p27 and target it for proteosomal degradation. In addition to promoting p27 degradation, phosphorylation also regulates p27 subcellular localization. Following mitogen stimulation, this $\mathrm{p} 27$ is likely to be phosphorylated on serine 10 by human kinase-interacting stathmin (hKis), which promotes nuclear export ${ }^{317}$. According to work done by Liang and Slingerland, ${ }^{318}$ p27 is also phosphorylated on two threonine residues, Thr157 and Thr198, by Akt, which results in the cytoplasmic retention of p27. The resultant cytoplasmic localization following the phosphorylation of p27 at Thr157 is due to inhibition of its nuclear import. Overall, this suggests a model in which mitogenic signaling pathways promote cytoplasmic localization of p27 and its subsequent degradation by the Kip1 ubiquitination-promoting complex (KPC). This will increase the activity of nuclear cyclin E-CDK2 resulting in p27 Thr187 phosphorylation and degradation of p27, leading to a positive feedback loop for enhancement of cyclin ECDK2 activity.

Sakakibara et al. showed that the ERK subfamily of MAPK is both essential and adequate in the regulation of p27 and a number of other studies have also established that ERK activity also contributes to the down-regulation of p2 $7^{319 ; 320-324}$. 


\section{The effects of ROS on regulators cell cycle}

There is increasing evidence suggesting that ROS and RNS play a part in the regulation of cell proliferation and cell-cycle control. Studies have shown that there is a significant similarity between the pathway that regulates cell cycle progression and the one that regulates the induction of apoptosis. These similar pathways are intimately interconnected by critical regulatory molecules and signal transduction cascades ${ }^{325}$.

Reactive oxygen and nitrogen species have a wide range of effects on cell-cycle advancement. The growth-inducing actions of ROS/RNS may be exerted via the activation of kinase signaling cascades, redox regulation of tyrosine phosphatases, and direct activation of transcription factors ${ }^{144}$.

Low concentrations of $\mathrm{H}_{2} \mathrm{O}_{2}$ increase cell proliferation through increased cyclin $\mathrm{D}$ expression and G1/S transition in fibroblasts ${ }^{326}$ and by means of decreased expression of p27 in prostate tumor spheroids ${ }^{327}$. Arnold et al. ${ }^{328}$ have also shown that $\mathrm{H}_{2} \mathrm{O}_{2}$ mediates cell growth and cell-cycle regulation caused by targeted overexpression of the Nox1 subunit of the NADPH oxidase ${ }^{328}$. The ability of ROS to promote the G1/S transition is further substantiated by the finding that treatment with antioxidants will repeatedly block proliferation and cell-cycle progression. This can be corroborated by the work of Menon et al. ${ }^{329}$, which showed that the antioxidant $N$-acetyl-L-cysteine induces G1 arrest by decreasing cyclin D1, increasing p27 protein levels, and leading to hypophosphorylation of $\mathrm{Rb}^{329}$. It is also noteworthy that low to moderate ROS can induce MAPK pathways 
that lead to cell growth and proliferation, whereas high ROS induce DNA damage and/or MAPK pathways that activate p53, cell arrest, and apoptosis ${ }^{326}$.

Growth arrest associated with higher, sustained levels of ROS and RNS appears to involve the induction of inhibitory cell-cycle control proteins, especially $\mathrm{p} 21$, and the repression of cyclins ${ }^{330}$. More recently, the redox-sensitive family of Forkhead box class $\mathrm{O}$ (FOXO) transcription factors has been shown to promote cell-cycle arrest in G1 by transcriptional up-regulation of the CDK inhibitor p27 and down-regulation of cyclin $\mathrm{D} 1^{331}$.

Very little is known about the redox control of the spindle assembly checkpoint. It has recently been suggested that mitotic spindle pole formation is an important component of $\mathrm{H}_{2} \mathrm{O}_{2}$-induced mitosis in type II pneumocytes ${ }^{332}$. Cdc2 and other mitotic protein kinases have also been shown to play a role in spindle regulation, ${ }^{333}$ suggesting a possible role of redox control of $\mathrm{Cdc} 2$ activation by $\mathrm{Cdc} 25 \mathrm{C}$ in the spindle checkpoint. The MAPK pathways, especially p38 and ERK1/2, ${ }^{334}$ which are regulated by ROS appear to play a key role in mitotic spindle assembly.

\section{The role of Redox signaling in Anti estrogen Resistance}

Based on the above review, we may therefore infer that redox signaling could contribute to anti-estrogen resistance by the following biological processes: induction of ROS by anti-estrogens and a subsequent inactivation of PTPs or MKPs resulting in the activation and hyper-stimulation of either the MAPK pathway or the PI3K/Akt pathway, which could either affect the cell cycle through the activation of transcription factors or the 
CDKI leading to a change from the tamoxifen sensitive phonotype to a tamoxifen resistant one.

Cancer cells are characterized by uncontrolled proliferation and altered energy metabolism. In response to the activation of many oncogenes, continuous mitogenic signaling augments the production of ROS. Additionally, mitogens like estrogen and antiestrogens such as tamoxifen have been shown lead to ROS production when they are exposed to cancer cells both in vitro and in vivo. The ROS and redox signaling that ensue result in the induction of replication stress and DNA damage response, which in conjunction with the functional checkpoint, induces senescenes, often considered a barrier to tumorigenesis ${ }^{335,336}$. Interestingly, once cancer cells have escaped the mechanisms that counteract mitogenic signaling, they advance to a pro-oxidative state typified by unbridled proliferation and altered energy metabolism, including defects in mitochondrial respiration.

Defects in mitochondrial respiration cause inactivation of PTEN in a redox-dependent manner and activation of the pro-survival factor $\mathrm{Akt}^{337}$. Akt is one of the kinases that phosphorylate $\mathrm{p} 27$ on the threonine 157 position resulting in cytoplamic sequestration of p27 with an ensuing loss in its cyclin kinase inhibitory function; a consequent unrestrained cell proliferation and a change from a tamoxifen sensitive to a tamoxifen resistant phenotype. Futhermore, activated Akt has been shown to phosphorylate the redox sensitive transcription factor NFR-1 thereby activating it and leading to its binding to the promoter region of cell cycle genes ${ }^{338}$. 
It is also probable that NRF-1 could be part of a pathway that connects the mitogenactivated signaling cascade (either the MAP kinase or the PI3K Akt pathway) to cell cycle progression. Following ROS production and the induction of a pro-oxidative state in cancer cells, PTPs are oxidized in a redox dependent manner, rendering them unable to carry out their usual function. In the case of Cdc25A this function is to inactivate the MAPKKK Raf-1, with which it has been shown to have an on/off switch like relationship $^{339}$. The inability of oxidized Cdc25A to inactivate Raf-1 results in a continuous activation of the MAP kinase pathway, with a consequent upregulation and nuclear translocation of ERK. The nuclear translocation of ERK enables it to phosphorylate NRF-1 protein causing it to bind to the promoter of certain cell cycle genes (unpublished work done in Dr Roy's lab) inducing their transcription and promoting cell proliferation.

Tumor suppressor genes also play an important role in linking metabolism to cell growth. A central regulator of metabolism is the $\mathrm{PI} 3 \mathrm{~K} / \mathrm{AKT}$ pathway, which controls metabolism through several mechanisms, including enhancement of protein translation through $\mathrm{mTOR}^{340}$. The c-Myc oncoprotein also plays a vital role in regulating metabolic changes required for cell division ${ }^{341}$. Furthermore, the pro-oxidative state of cancer cells is typified by adjustive responses that include changes in the expression of antioxidant enzymes and increased production of GSH. Together the interconnected disturbance in metabolism and oxidant production common to most tumor cells provide therapeutic 
opportunities that do not depend on targeting a single oncogene or tumor suppressor gene.

\section{List of References}

(1) Riggins RB, Schrecengost RS, Guerrero MS, Bouton AH. Pathways to tamoxifen resistance. Cancer Lett 2007 October 18;256(1):1-24.

(2) Fisher B, Costantino JP, Wickerham DL et al. Tamoxifen for prevention of breast cancer: report of the National Surgical Adjuvant Breast and Bowel Project P-1 Study. $J$ Natl Cancer Inst 1998 September 16;90(18):1371-88.

(3) Fisher B, Costantino JP, Wickerham DL et al. Tamoxifen for the prevention of breast cancer: current status of the National Surgical Adjuvant Breast and Bowel Project P-1 study. J Natl Cancer Inst 2005 November 16;97(22):1652-62.

(4) Janicke R.U. PAGKA. A novel Arabidopsis thaliana protein protects tumor cells from tumor necrosis factor-induced apoptosis. 1402[1], 70-78. 1998. Biochimica et

Biophysica Acta - Molecular Cell Research.

Ref Type: Generic

(5) Cerutti P. Oxidant tumor promoters. 239-247. 1988. Growth Factors, Tumor

Promotors and Cancer Genes.

Ref Type: Generic

(6) Wilmer WATLCDJADMaRBH. Interleukin-1beta induction of mitogen-activated protein kinases in human mesangial cells. Role of oxidation. ., . 272, 10877-10881. 1997. J. Biol. Chem.

Ref Type: Generic

(7) Thannickal VJ, Fanburg BL. Reactive oxygen species in cell signaling. Am J Physiol Lung Cell Mol Physiol 2000 December;279(6):L1005-L1028.

(8) Fruehauf JP MFJ. Reactive oxygen species: a breath of life or death. 13 [3], 789-794. 2-1-0007. Cancer Res.

Ref Type: Generic

(9) Kamata H KH. Redox regulation of cellular signalling. 11[1], 1-14. 1999. Cell Signal.

Ref Type: Generic

(10) Lewis JS, Jordan VC. Selective estrogen receptor modulators (SERMs): mechanisms of anticarcinogenesis and drug resistance. Mutat Res 2005 December 11;591(1-2):24763. 
(11) Riggins RB, Bouton AH, Liu MC, Clarke R. Antiestrogens, aromatase inhibitors, and apoptosis in breast cancer. Vitam Horm 2005;71:201-37.

(12) Bouker KB, Skaar TC, Fernandez DR et al. interferon regulatory factor-1 mediates the proapoptotic but not cell cycle arrest effects of the steroidal antiestrogen ICI 182,780 (faslodex, fulvestrant). Cancer Res 2004 June 1;64(11):4030-9.

(13) MacGregor JI, Jordan VC. Basic guide to the mechanisms of antiestrogen action. Pharmacol Rev 1998 June;50(2):151-96.

(14) Arpino G, Green SJ, Allred DC et al. HER-2 amplification, HER-1 expression, and tamoxifen response in estrogen receptor-positive metastatic breast cancer: a southwest oncology group study. Clin Cancer Res 2004 September 1;10(17):5670-6.

(15) Gee JM, Robertson JF, Gutteridge E et al. Epidermal growth factor receptor/HER2/insulin-like growth factor receptor signalling and oestrogen receptor activity in clinical breast cancer. Endocr Relat Cancer 2005 July; 12 Suppl 1:S99-S111.

(16) Dowsett M, Johnston S, Martin LA et al. Growth factor signalling and response to endocrine therapy: the Royal Marsden Experience. Endocr Relat Cancer 2005 July; 12 Suppl 1:S113-S117.

(17) Howell A. Pure oestrogen antagonists for the treatment of advanced breast cancer. Endocr Relat Cancer 2006 September;13(3):689-706.

(18) Gutierrez MC, Detre S, Johnston S et al. Molecular changes in tamoxifen-resistant breast cancer: relationship between estrogen receptor, HER-2, and p38 mitogen-activated protein kinase. J Clin Oncol 2005 April 10;23(11):2469-76.

(19) Couse JF, Curtis HS, Korach KS. Receptor null mice reveal contrasting roles for estrogen receptor alpha and beta in reproductive tissues. J Steroid Biochem Mol Biol 2000 November 30;74(5):287-96.

(20) Krege JH, Hodgin JB, Couse JF et al. Generation and reproductive phenotypes of mice lacking estrogen receptor beta. Proc Natl Acad Sci US A 1998 December 22;95(26):15677-82.

(21) Lubahn DB, Moyer JS, Golding TS, Couse JF, Korach KS, Smithies O. Alteration of reproductive function but not prenatal sexual development after insertional disruption of the mouse estrogen receptor gene. Proc Natl Acad Sci U S A 1993 December 1;90(23):11162-6.

(22) Srivastava S, Toraldo G, Weitzmann MN, Cenci S, Ross FP, Pacifici R. Estrogen decreases osteoclast formation by down-regulating receptor activator of NF-kappa B ligand (RANKL)-induced JNK activation. J Biol Chem 2001 March 23;276(12):8836-40. 
(23) Migliaccio A, Di DM, Castoria G et al. Tyrosine kinase/p21ras/MAP-kinase pathway activation by estradiol-receptor complex in MCF-7 cells. EMBO J 1996 March $15 ; 15(6): 1292-300$.

(24) Razandi M, Pedram A, Levin ER. Plasma membrane estrogen receptors signal to antiapoptosis in breast cancer. Mol Endocrinol 2000 September;14(9):1434-47.

(25) Farach-Carson MC, Davis PJ. Steroid hormone interactions with target cells: cross talk between membrane and nuclear pathways. J Pharmacol Exp Ther 2003 December;307(3):839-45.

(26) Marino M, Ascenzi P. Do steroid hormones function via multiple signaling pathways? IUBMB Life 2005 December;57(12):825-7.

(27) Levin ER. Cell localization, physiology, and nongenomic actions of estrogen receptors. J Appl Physiol 2001 October;91(4):1860-7.

(28) Feron O, Saldana F, Michel JB, Michel T. The endothelial nitric-oxide synthasecaveolin regulatory cycle. $J$ Biol Chem 1998 February 6;273(6):3125-8.

(29) Flouriot G, Brand H, Denger S et al. Identification of a new isoform of the human estrogen receptor-alpha (hER-alpha) that is encoded by distinct transcripts and that is able to repress hER-alpha activation function 1. EMBO J 2000 September 1;19(17):4688-700.

(30) Glass CK, Rose DW, Rosenfeld MG. Nuclear receptor coactivators. Curr Opin Cell Biol 1997 April;9(2):222-32.

(31) Greene GL, Closs LE, Fleming H, DeSombre ER, Jensen EV. Antibodies to estrogen receptor: immunochemical similarity of estrophilin from various mammalian species. Proc Natl Acad Sci U S A 1977 September;74(9):3681-5.

(32) Greene GL, Sobel NB, King WJ, Jensen EV. Immunochemical studies of estrogen receptors. J Steroid Biochem 1984 January;20(1):51-6.

(33) Parker MG. Structure and function of estrogen receptors. Vitam Horm 1995;51:26787.

(34) Kahlert S, Nuedling S, van EM, Vetter H, Meyer R, Grohe C. Estrogen receptor alpha rapidly activates the IGF-1 receptor pathway. J Biol Chem 2000 June $16 ; 275(24): 18447-53$.

(35) Song RX, McPherson RA, Adam L et al. Linkage of rapid estrogen action to MAPK activation by ERalpha-Shc association and Shc pathway activation. Mol Endocrinol 2002 January;16(1):116-27.

(36) Migliaccio A, Di DM, Castoria G et al. Tyrosine kinase/p21ras/MAP-kinase pathway activation by estradiol-receptor complex in MCF-7 cells. EMBOJ 1996 March $15 ; 15(6): 1292-300$. 
(37) Wehling M. Specific, nongenomic actions of steroid hormones. Anпи Rev Physiol 1997;59:365-93.

(38) Revelli A, Massobrio M, Tesarik J. Nongenomic actions of steroid hormones in reproductive tissues. Endocr Rev 1998 February;19(1):3-17.

(39) Razandi M, Alton G, Pedram A, Ghonshani S, Webb P, Levin ER. Identification of a structural determinant necessary for the localization and function of estrogen receptor alpha at the plasma membrane. Mol Cell Biol 2003 March;23(5):1633-46.

(40) Wong CW, McNally C, Nickbarg E, Komm BS, Cheskis BJ. Estrogen receptorinteracting protein that modulates its nongenomic activity-crosstalk with Src/Erk phosphorylation cascade. Proc Natl Acad Sci U S A 2002 November 12;99(23):14783-8.

(41) Kelly MJ, Levin ER. Rapid actions of plasma membrane estrogen receptors. Trends Endocrinol Metab 2001 May;12(4):152-6.

(42) Figtree GA, McDonald D, Watkins H, Channon KM. Truncated estrogen receptor alpha 46-kDa isoform in human endothelial cells: relationship to acute activation of nitric oxide synthase. Circulation 2003 January 7;107(1):120-6.

(43) Lewis JS, Jordan VC. Selective estrogen receptor modulators (SERMs): mechanisms of anticarcinogenesis and drug resistance. Mutat Res 2005 December 11;591(1-2):24763.

(44) Elledge RM, Osborne CK. Oestrogen receptors and breast cancer. BMJ 1997 June 28;314(7098):1843-4.

(45) Musgrove EA, Hamilton JA, Lee CS, Sweeney KJ, Watts CK, Sutherland RL. Growth factor, steroid, and steroid antagonist regulation of cyclin gene expression associated with changes in T-47D human breast cancer cell cycle progression. Mol Cell Biol 1993 June;13(6):3577-87.

(46) Musgrove EA, Hamilton JA, Lee CS, Sweeney KJ, Watts CK, Sutherland RL. Growth factor, steroid, and steroid antagonist regulation of cyclin gene expression associated with changes in T-47D human breast cancer cell cycle progression. Mol Cell Biol 1993 June;13(6):3577-87.

(47) Jordan VC, Murphy CS. Endocrine pharmacology of antiestrogens as antitumor agents. Endocr Rev 1990 November;11(4):578-610.

(48) Musgrove EA, Hamilton JA, Lee CS, Sweeney KJ, Watts CK, Sutherland RL. Growth factor, steroid, and steroid antagonist regulation of cyclin gene expression associated with changes in T-47D human breast cancer cell cycle progression. Mol Cell Biol 1993 June;13(6):3577-87. 
(49) Sutherland RL, Hall RE, Taylor IW. Cell proliferation kinetics of MCF-7 human mammary carcinoma cells in culture and effects of tamoxifen on exponentially growing and plateau-phase cells. Cancer Res 1983 September;43(9):3998-4006.

(50) Otto AM, Paddenberg R, Schubert S, Mannherz HG. Cell-cycle arrest, micronucleus formation, and cell death in growth inhibition of MCF-7 breast cancer cells by tamoxifen and cisplatin. J Cancer Res Clin Oncol 1996;122(10):603-12.

(51) Osborne CK, Boldt DH, Clark GM, Trent JM. Effects of tamoxifen on human breast cancer cell cycle kinetics: accumulation of cells in early G1 phase. Cancer Res 1983 August;43(8):3583-5.

(52) Butt AJ, McNeil CM, Musgrove EA, Sutherland RL. Downstream targets of growth factor and oestrogen signalling and endocrine resistance: the potential roles of c-Myc, cyclin D1 and cyclin E. Endocr Relat Cancer 2005 July;12 Suppl 1:S47-S59.

(53) Jordan VC. Effect of tamoxifen (ICI 46,474) on initiation and growth of DMBAinduced rat mammary carcinomata. Eur J Cancer 1976 June;12(6):419-24.

(54) Gottardis MM, Jordan VC. Antitumor actions of keoxifene and tamoxifen in the Nnitrosomethylurea-induced rat mammary carcinoma model. Cancer Res 1987 August $1 ; 47(15): 4020-4$.

(55) Huynh HT, Pollak M. Insulin-like growth factor I gene expression in the uterus is stimulated by tamoxifen and inhibited by the pure antiestrogen ICI 182780. Cancer Res 1993 December 1;53(23):5585-8.

(56) Hyder SM, Stancel GM, Chiappetta C, Murthy L, Boettger-Tong HL, Makela S. Uterine expression of vascular endothelial growth factor is increased by estradiol and tamoxifen. Cancer Res 1996 September 1;56(17):3954-60.

(57) Noguchi S, Motomura K, Inaji H, Imaoka S, Koyama H. Down-regulation of transforming growth factor-alpha by tamoxifen in human breast cancer. Cancer 1993 July 1;72(1):131-6.

(58) Butta A, MacLennan K, Flanders KC et al. Induction of transforming growth factor beta 1 in human breast cancer in vivo following tamoxifen treatment. Cancer Res 1992 August 1;52(15):4261-4.

(59) Makris A, Powles TJ, Allred DC et al. Changes in hormone receptors and proliferation markers in tamoxifen treated breast cancer patients and the relationship with response. Breast Cancer Res Treat 1998 March;48(1):11-20.

(60) Newton CJ, Butta A, Nicholls J, Dowsett M. Oestradiol synthesis from oestrone in malignant breast epithelial cells: studies on a high affinity, $80 \mathrm{kDa}$ form of oestradiol dehydrogenase. J Steroid Biochem Mol Biol 1992 September;42(8):891-900. 
(61) Forman HJ, Fukuto JM, Torres M. Redox signaling: thiol chemistry defines which reactive oxygen and nitrogen species can act as second messengers. Am J Physiol Cell Physiol 2004 August;287(2):C246-C256.

(62) Schreck R. RPaBPA. Reactive oxygen expression of manganese superoxide dismutase in 7,124imethyl- benz(a)anthracene-induced ovarian cancer and increased serum levels in the tumor-bearing rats. 13, 1941-1947. 1991. Carcinogenesis. Ref Type: Generic

(63) Chen Q, Olashaw N, Wu J. Participation of reactive oxygen species in the lysophosphatidic acid-stimulated mitogen-activated protein kinase kinase activation pathway. J Biol Chem 1995 December 1;270(48):28499-502.

(64) Lander H.M. OJSTKKaNA. p21ras as a common signaling target of reactive free radicals and cellular redox stress. 270, 21195-21198. 1995. J. Biol. Chem.

Ref Type: Generic

(65) Russo T. ZNEFARCFFMJJOPMACWaAE. A p53-independent pathway for activation of WAF11CIP 1 expression following oxidative stress. 270, 29386 29391. 1995. J. Biol. Chem.

Ref Type: Generic

(66) Sundaresan M, Yu ZX, Ferrans VJ, Irani K, Finkel T. Requirement for generation of $\mathrm{H} 2 \mathrm{O} 2$ for platelet-derived growth factor signal transduction. Science 1995 October 13;270(5234):296-9.

(67) Shibanuma M. KTaNK. (1988). Induction of DNA replication and expression of proto-oncogenes c-myc and c-fos in quiescent Balbl3T3 cells by xanihinelxanthine oxidase. 3, 17-21. 2011. Oncogene.

Ref Type: Generic

(68) Hockenbery DM OZYX-MMCKS. Bcl-2 functions in an anti-oxidant pathway to prevent apoptosis. 75, 241-251. 1993. Cell.

Ref Type: Generic

(69) De Haan JB CFIRBCKMKI. Elevation in the ratio of $\mathrm{Cu} / \mathrm{Zn}$-superoxide dismutase to glutathione peroxidase activity induces features of cellular senescence and this effect is mediated by hydrogen peroxide. 5, 283-292. 1996. Hum Mol Genet . Ref Type: Generic

(70) Bae YS, Kang SW, Seo MS et al. Epidermal growth factor (EGF)-induced generation of hydrogen peroxide. Role in EGF receptor-mediated tyrosine phosphorylation. J Biol Chem 1997 January 3;272(1):217-21.

(71) Roy D, Cai Q, Felty Q, Narayan S. Estrogen-induced generation of reactive oxygen and nitrogen species, gene damage, and estrogen-dependent cancers. $J$ Toxicol Environ Health B Crit Rev 2007 June;10(4):235-57. 
(72) Droge W. Free radicals in the physiological control of cell function. Physiol Rev 2002 January;82(1):47-95.

(73) Valko M, Rhodes CJ, Moncol J, Izakovic M, Mazur M. Free radicals, metals and antioxidants in oxidative stress-induced cancer. Chem Biol Interact 2006 March 10;160(1):1-40.

(74) Finkel T. Redox-dependent signal transduction. FEBS Lett 2000 June 30;476(12):52-4.

(75) Finkel T. Oxygen radicals and signaling. Curr Opin Cell Biol 1998 April;10(2):24853.

(76) Forman HJ, Fukuto JM, Torres M. Redox signaling: thiol chemistry defines which reactive oxygen and nitrogen species can act as second messengers. Am J Physiol Cell Physiol 2004 August;287(2):C246-C256.

(77) Palozza PAGPEBGM. Different role of lipid peroxidation in oxidative stressinduced lethal injury in normal and tumor thymocytes. 312, 88-94. 1994. Arch. Biochem. Biophys. Ref Type: Generic

(78) Loeb LJEWASKaKS. Mutagenisis by oxygen free radicals in vitro. 28, 162-168. 1988. Proc. Am. Assoc. Cancer Res.

Ref Type: Generic

(79) Cerutti P. The role of active oxygen in tumor promotion. 167-176. 1986. New York, In Harris,C. (ed.) Biochemical and Molecular Epidemiology of Cancer.

Ref Type: Generic

(80) Troll WaWR. The role of oxygen radicals as a possible mechanism of tumor promotion. 25, 509-528. 1985. Annu. Rev. Pharmacol. Toxicol.

Ref Type: Generic

(81) Amstad PLHIMBIKaTBF. Manganese superoxide dismutase inhibits soft agar growth in JB6 clone 41 mouse epidermal cells. 18, 479-484. 1997. Carcinogenesis. Ref Type: Generic

(82) Kennedy ATWaLJ. Role of free radicals in the initiation and promotion of radiation transformation in vitro. Carcinogenesis. 5, 1213-1218. 1984.

Ref Type: Generic

(83) Higuchi M, Honda T, Proske RJ, Yeh ET. Regulation of reactive oxygen speciesinduced apoptosis and necrosis by caspase 3-like proteases. Oncogene 1998 November 26;17(21):2753-60.

(84) Shen HM, Lin Y, Choksi S et al. Essential roles of receptor-interacting protein and TRAF2 in oxidative stress-induced cell death. Mol Cell Biol 2004 July;24(13):5914-22. 
(85) Babior BM. NADPH oxidase: an update. Blood 1999 March 1;93(5):1464-76.

(86) Hancock JT, Desikan R, Neill SJ. Role of reactive oxygen species in cell signalling pathways. Biochem Soc Trans 2001 May;29(Pt 2):345-50.

(87) Inoue M, Sato EF, Nishikawa M et al. Mitochondrial generation of reactive oxygen species and its role in aerobic life. Curr Med Chem 2003 December;10(23):2495-505.

(88) Fialkow L, Wang Y, Downey GP. Reactive oxygen and nitrogen species as signaling molecules regulating neutrophil function. Free Radic Biol Med 2007 January $15 ; 42(2): 153-64$.

(89) Halliwell B, Gutteridge JM. The definition and measurement of antioxidants in biological systems. Free Radic Biol Med 1995 January;18(1):125-6.

(90) Felty Q, Xiong WC, Sun D et al. Estrogen-induced mitochondrial reactive oxygen species as signal-transducing messengers. Biochemistry 2005 May 10;44(18):6900-9.

(91) Kulmacz RJ, van der Donk WA, Tsai AL. Comparison of the properties of prostaglandin H synthase-1 and -2. Prog Lipid Res 2003 September;42(5):377-404.

(92) Larfars G, Gyllenhammar H. Stimulus-dependent transduction mechanisms for nitric oxide release in human polymorphonuclear neutrophil leukocytes. J Lab Clin Med 1998 July;132(1):54-60.

(93) Larfars G, Lantoine F, Devynck MA, Gyllenhammar H. Electrochemical detection of nitric oxide production in human polymorphonuclear neutrophil leukocytes. Scand $J$ Clin Lab Invest 1999 August;59(5):361-8.

(94) Felty Q, Roy D. Mitochondrial signals to nucleus regulate estrogen-induced cell growth. Med Hypotheses 2005;64(1):133-41.

(95) A.Sharga QFaDR. The influence of alcohol on estrogen-induced stimulation of cells in part occurs through reactive oxygen species. Proc Am Assoc Cancer Res $2003 ; 44: 1200$.

(96) S.Venkat QFaDR. Estrogen-induced stimulation of macrophages leading to the generation of reactive oxygen species in the target organ of cancer. The Toxicologist $2003 ; 235$.

(97) Felty Q, Roy D. Mitochondrial signals to nucleus regulate estrogen-induced cell growth. Med Hypotheses 2005;64(1):133-41.

(98) Taylor ER, Hurrell F, Shannon RJ, Lin TK, Hirst J, Murphy MP. Reversible glutathionylation of complex I increases mitochondrial superoxide formation. J Biol Chem 2003 May 30;278(22):19603-10. 
(99) Roy D, Cai Q. Estrogen, immunoactivation, gene damage, and development of breast, endometrial, ovarian, prostate, and testicular cancers. Recent Res Dev Steroid Biochem Mol Biol 2002;3:1-32.

(100) Roy D, Singh KP. Estrogen-induced genetic alterations and their role in carcinogenicity. Current Genomics 2004;5(3):245-57.

(101) Kong LY, Szaniszlo P, Albrecht T, Liehr JG. Frequency and molecular analysis of hprt mutations induced by estradiol in Chinese hamster V79 cells. Int J Oncol 2000 December;17(6):1141-9.

(102) Singh K L-GJL-BAaRD. Estrogen-induced mutations and its role in the development of tumorigenesis. Hormonal Carcinogenesis IV, Springer-Verlag, New York 2005;475-9.

(103) Felty Q. Estrogen-induced DNA synthesis in vascular endothelial cells is mediated by ROS signaling. BMC Cardiovasc Disord 2006;6:16.

(104) Felty Q, Singh KP, Roy D. Estrogen-induced G1/S transition of G0-arrested estrogen-dependent breast cancer cells is regulated by mitochondrial oxidant signaling. Oncogene 2005 July 21;24(31):4883-93.

(105) Jordan VC. Molecular mechanisms of antiestrogen action in breast cancer. Breast Cancer Res Treat 1994;31(1):41-52.

(106) Kang Y, Cortina R, Perry RR. Role of c-myc in tamoxifen-induced apoptosis estrogen-independent breast cancer cells. J Natl Cancer Inst 1996 March 6;88(5):279-84.

(107) Ellis PA, Saccani-Jotti G, Clarke R et al. Induction of apoptosis by tamoxifen and ICI 182780 in primary breast cancer. Int J Cancer 1997 August 7;72(4):608-13.

(108) Keen JC, Dixon JM, Miller EP et al. The expression of Ki-S1 and BCL-2 and the response to primary tamoxifen therapy in elderly patients with breast cancer. Breast Cancer Res Treat 1997 June;44(2):123-33.

(109) Ferlini C, Scambia G, Marone M et al. Tamoxifen induces oxidative stress and apoptosis in oestrogen receptor-negative human cancer cell lines. Br J Cancer 1999 January;79(2):257-63.

(110) Kim JA, Kang YS, Jung MW, Lee SH, Lee YS. Involvement of Ca2+ influx in the mechanism of tamoxifen-induced apoptosis in HepG2 human hepatoblastoma cells. Cancer Lett 1999 December 1;147(1-2):115-23.

(111) Lee YS, Kang YS, Lee SH, Kim JA. Role of NAD(P)H oxidase in the tamoxifeninduced generation of reactive oxygen species and apoptosis in HepG2 human hepatoblastoma cells. Cell Death Differ 2000 October;7(10):925-32. 
(112) Kallio A, Zheng A, Dahllund J, Heiskanen KM, Harkonen P. Role of mitochondria in tamoxifen-induced rapid death of MCF-7 breast cancer cells. Apoptosis 2005 December;10(6):1395-410.

(113) Babior BM. The respiratory burst oxidase. Curr Opin Hematol 1995 January;2(1):55-60.

(114) Jones SA, O'Donnell VB, Wood JD, Broughton JP, Hughes EJ, Jones OT. Expression of phagocyte NADPH oxidase components in human endothelial cells. Am J Physiol 1996 October;271(4 Pt 2):H1626-H1634.

(115) Marshall C, Mamary AJ, Verhoeven AJ, Marshall BE. Pulmonary artery NADPHoxidase is activated in hypoxic pulmonary vasoconstriction. Am J Respir Cell Mol Biol 1996 November;15(5):633-44.

(116) Youngson C, Nurse C, Yeger H et al. Immunocytochemical localization on O2sensing protein (NADPH oxidase) in chemoreceptor cells. Microsc Res Tech 1997 April $1 ; 37(1): 101-6$.

(117) Kummer W, Acker H. Immunohistochemical demonstration of four subunits of neutrophil NAD(P)H oxidase in type I cells of carotid body. J Appl Physiol 1995 May;78(5):1904-9.

(118) Ehleben W, Porwol T, Fandrey J, Kummer W, Acker H. Cobalt and desferrioxamine reveal crucial members of the oxygen sensing pathway in HepG2 cells. Kidney Int 1997 February;51(2):483-91.

(119) Cool RH, Merten E, Theiss C, Acker H. Rac1, and not Rac2, is involved in the regulation of the intracellular hydrogen peroxide level in HepG2 cells. Biochem J 1998 May 15;332 ( Pt 1):5-8.

(120) Kuo YM, Chen HH, Shieh CC, Chuang KP, Cherng CG, Yu L. 4Hydroxytamoxifen attenuates methamphetamine-induced nigrostriatal dopaminergic toxicity in intact and gonadetomized mice. J Neurochem 2003 December;87(6):1436-43.

(121) Lacort M, Leal AM, Liza M, Martin C, Martinez R, Ruiz-Larrea MB. Protective effect of estrogens and catecholestrogens against peroxidative membrane damage in vitro. Lipids 1995 February;30(2):141-6.

(122) Wakade C, Khan MM, De Sevilla LM, Zhang QG, Mahesh VB, Brann DW. Tamoxifen neuroprotection in cerebral ischemia involves attenuation of kinase activation and superoxide production and potentiation of mitochondrial superoxide dismutase.

Endocrinology 2008 January;149(1):367-79.

(123) Custodio JB, Dinis TC, Almeida LM, Madeira VM. Tamoxifen and hydroxytamoxifen as intramembraneous inhibitors of lipid peroxidation. Evidence for peroxyl radical scavenging activity. Biochem Pharmacol 1994 June 1;47(11):1989-98. 
(124) Zhao Y, Wang LM, Chaiswing L et al. Tamoxifen protects against acute tumor necrosis factor alpha-induced cardiac injury via improving mitochondrial functions. Free Radic Biol Med 2006 April 1;40(7):1234-41.

(125) Lim JS, Frenkel K, Troll W. Tamoxifen suppresses tumor promoter-induced hydrogen peroxide formation by human neutrophils. Cancer Res 1992 September 15;52(18):4969-72.

(126) Arteaga E, Villaseca P, Bianchi M, Rojas A, Marshall G. Raloxifene is a better antioxidant of low-density lipoprotein than estradiol or tamoxifen in postmenopausal women in vitro. Menopause 2003 March;10(2):142-6.

(127) Radice S, Fumagalli R, Chiesara E, Ferraris M, Frigerio S, Marabini L. Estrogenic activity of procymidone in rainbow trout (Oncorhynchus mykiss) hepatocytes: a possible mechanism of action. Chem Biol Interact 2004 March 15;147(2):185-93.

(128) Kovacic P, Jacintho JD. Mechanisms of carcinogenesis: focus on oxidative stress and electron transfer. Curr Med Chem 2001 June;8(7):773-96.

(129) Oberley LW, Ridnour LA, Sierra-Rivera E, Oberley TD, Guernsey DL. Superoxide dismutase activities of differentiating clones from an immortal cell line. J Cell Physiol 1989 January;138(1):50-60.

(130) Valko M, Morris H, Mazur M, Rapta P, Bilton RF. Oxygen free radical generating mechanisms in the colon: do the semiquinones of vitamin $\mathrm{K}$ play a role in the aetiology of colon cancer? Biochim Biophys Acta 2001 August 15;1527(3):161-6.

(131) Valko M, Leibfritz D, Moncol J, Cronin MT, Mazur M, Telser J. Free radicals and antioxidants in normal physiological functions and human disease. Int J Biochem Cell Biol 2007;39(1):44-84.

(132) Valko M, Leibfritz D, Moncol J, Cronin MT, Mazur M, Telser J. Free radicals and antioxidants in normal physiological functions and human disease. Int J Biochem Cell Biol 2007;39(1):44-84.

(133) Sen CK. Cellular thiols and redox-regulated signal transduction. Curr Top Cell Regul 2000;36:1-30.

(134) Biswas S, Chida AS, Rahman I. Redox modifications of protein-thiols: emerging roles in cell signaling. Biochem Pharmacol 2006 February 28;71(5):551-64.

(135) Kamata H, Hirata H. Redox regulation of cellular signalling. Cell Signal 1999 January;11(1):1-14.

(136) Fruehauf JP, Meyskens FL, Jr. Reactive oxygen species: a breath of life or death? Clin Cancer Res 2007 February 1;13(3):789-94. 
(137) Schafer FQ, Buettner GR. Redox environment of the cell as viewed through the redox state of the glutathione disulfide/glutathione couple. Free Radic Biol Med 2001 June 1;30(11):1191-212.

(138) Forman HJ, Fukuto JM, Torres M. Redox signaling: thiol chemistry defines which reactive oxygen and nitrogen species can act as second messengers. Am J Physiol Cell Physiol 2004 August;287(2):C246-C256.

(139) Sundaresan M, Yu ZX, Ferrans VJ, Irani K, Finkel T. Requirement for generation of $\mathrm{H} 2 \mathrm{O} 2$ for platelet-derived growth factor signal transduction. Science 1995 October 13;270(5234):296-9.

(140) Deshpande NN, Sorescu D, Seshiah P et al. Mechanism of hydrogen peroxideinduced cell cycle arrest in vascular smooth muscle. Antioxid Redox Signal 2002 October;4(5):845-54.

(141) Immenschuh S, Baumgart-Vogt E. Peroxiredoxins, oxidative stress, and cell proliferation. Antioxid Redox Signal 2005 May;7(5-6):768-77.

(142) Li VG, Sacerdoti D, Sangras B et al. Carbon monoxide signaling in promoting angiogenesis in human microvessel endothelial cells. Antioxid Redox Signal 2005 May;7(5-6):704-10.

(143) Menon SG, Coleman MC, Walsh SA, Spitz DR, Goswami PC. Differential susceptibility of nonmalignant human breast epithelial cells and breast cancer cells to thiol antioxidant-induced G(1)-delay. Antioxid Redox Signal 2005 May;7(5-6):711-8.

(144) Rothstein EC, Lucchesi PA. Redox control of the cell cycle: a radical encounter. Antioxid Redox Signal 2005 May;7(5-6):701-3.

(145) Sun Y. Antioxidant enzymes, and carcinogenesis.

Free Radic. Biol. Med. . 8, 583-599. 1990. Free radicals Biol Med.

Ref Type: Generic

(146) Oberiey T.D.and Oberley L.W. Oxygen radicals and cancer. In:Free radicals in aging. 248-267. 1993.

Ref Type: Generic

(147) Oberley L.W.and Oberley T.D. Reactive oxygen species in the aetiology of cancer. In: Drugs, diet and disease. 1, 47-63. 1994.

Ref Type: Generic

(148) T.D.Oberley and L.W.Oberley. Antioxidant enzyme levels in cancer. 12, 525-535. 1997.

Ref Type: Generic 
(149) Forman HJ, Fukuto JM, Torres M. Redox signaling: thiol chemistry defines which reactive oxygen and nitrogen species can act as second messengers. Am J Physiol Cell Physiol 2004 August;287(2):C246-C256.

(150) Cooper CE, Patel RP, Brookes PS, rley-Usmar VM. Nanotransducers in cellular redox signaling: modification of thiols by reactive oxygen and nitrogen species. Trends Biochem Sci 2002 October;27(10):489-92.

(151) Barrett WC, DeGnore JP, Keng YF, Zhang ZY, Yim MB, Chock PB. Roles of superoxide radical anion in signal transduction mediated by reversible regulation of protein-tyrosine phosphatase 1B. J Biol Chem 1999 December 3;274(49):34543-6.

(152) Abate C, Patel L, Rauscher FJ, III, Curran T. Redox regulation of fos and jun DNA-binding activity in vitro. Science 1990 September 7;249(4973):1157-61.

(153) Matthews JR, Wakasugi N, Virelizier JL, Yodoi J, Hay RT. Thioredoxin regulates the DNA binding activity of NF-kappa B by reduction of a disulphide bond involving cysteine 62. Nucleic Acids Res 1992 August 11;20(15):3821-30.

(154) Arrigo AP. Gene expression and the thiol redox state. Free Radic Biol Med 1999 November;27(9-10):936-44.

(155) Suzuki YJ, Forman HJ, Sevanian A. Oxidants as stimulators of signal transduction. Free Radic Biol Med 1997;22(1-2):269-85.

(156) Nakamura H, Nakamura K, Yodoi J. Redox regulation of cellular activation. Annu Rev Immunol 1997;15:351-69.

(157) Powis G, Gasdaska JR, Baker A. Redox signaling and the control of cell growth and death. Adv Pharmacol 1997;38:329-59.

(158) Sen CK, Packer L. Antioxidant and redox regulation of gene transcription. FASEB $J 1996$ May;10(7):709-20.

(159) Shackelford RE, Kaufmann WK, Paules RS. Oxidative stress and cell cycle checkpoint function. Free Radic Biol Med 2000 May 1;28(9):1387-404.

(160) Finkel T. Signal transduction by reactive oxygen species in non-phagocytic cells. $J$ Leukoc Biol 1999 March;65(3):337-40.

(161) Maulik N. Redox signaling of angiogenesis. Antioxid Redox Signal 2002 October;4(5):805-15.

(162) Rhee SG. Redox signaling: hydrogen peroxide as intracellular messenger. Exp Mol Med 1999 June 30;31(2):53-9. 
(163) Wink DA, Mitchell JB. Chemical biology of nitric oxide: Insights into regulatory, cytotoxic, and cytoprotective mechanisms of nitric oxide. Free Radic Biol Med 1998 September;25(4-5):434-56.

(164) Wolin MS. Interactions of oxidants with vascular signaling systems. Arterioscler Thromb Vasc Biol 2000 June;20(6):1430-42.

(165) Abate C, Patel L, Rauscher FJ, III, Curran T. Redox regulation of fos and jun DNA-binding activity in vitro. Science 1990 September 7;249(4973):1157-61.

(166) Haufel T, Dormann S, Hanusch J, Schwieger A, Bauer G. Three distinct roles for TGF-beta during intercellular induction of apoptosis: a review. Anticancer Res 1999 January;19(1A):105-11.

(167) Denu JM, Tanner KG. Specific and reversible inactivation of protein tyrosine phosphatases by hydrogen peroxide: evidence for a sulfenic acid intermediate and implications for redox regulation. Biochemistry 1998 April 21;37(16):5633-42.

(168) Holmgren A. Thioredoxin structure and mechanism: conformational changes on oxidation of the active-site sulfhydryls to a disulfide. Structure 1995 March 15;3(3):23943.

(169) Klatt P, Molina EP, De Lacoba MG et al. Redox regulation of c-Jun DNA binding by reversible S-glutathiolation. FASEB J 1999 September;13(12):1481-90.

(170) Nishi T, Shimizu N, Hiramoto M et al. Spatial redox regulation of a critical cysteine residue of NF-kappa B in vivo. J Biol Chem 2002 November 15;277(46):4454856.

(171) Brady KD, Giegel DA, Grinnell C et al. A catalytic mechanism for caspase-1 and for bimodal inhibition of caspase-1 by activated aspartic ketones. Bioorg Med Chem 1999 April; 7(4):621-31.

(172) Rudolph J. Redox regulation of the Cdc25 phosphatases. Antioxid Redox Signal 2005 May;7(5-6):761-7.

(173) Hecht D, Zick Y. Selective inhibition of protein tyrosine phosphatase activities by $\mathrm{H} 2 \mathrm{O} 2$ and vanadate in vitro. Biochem Biophys Res Commun 1992 October 30;188(2):773-9.

(174) Heffetz D, Rutter WJ, Zick Y. The insulinomimetic agents $\mathrm{H} 2 \mathrm{O} 2$ and vanadate stimulate tyrosine phosphorylation of potential target proteins for the insulin receptor kinase in intact cells. Biochem J 1992 December 1;288 ( Pt 2):631-5.

(175) Lee SR, Kwon KS, Kim SR, Rhee SG. Reversible inactivation of protein-tyrosine phosphatase 1B in A431 cells stimulated with epidermal growth factor. J Biol Chem 1998 June 19;273(25):15366-72. 
(176) Shifrin VI, Davis RJ, Neel BG. Phosphorylation of protein-tyrosine phosphatase PTP-1B on identical sites suggests activation of a common signaling pathway during mitosis and stress response in mammalian cells. J Biol Chem 1997 January 31;272(5):2957-62.

(177) Finkel T. Oxygen radicals and signaling. Curr Opin Cell Biol 1998 April;10(2):248-53.

(178) Finkel T. Redox-dependent signal transduction. FEBS Lett 2000 June 30;476(12):52-4.

(179) Tonks NK. Redox redux: revisiting PTPs and the control of cell signaling. Cell 2005 June 3;121(5):667-70.

(180) Salmeen A, Barford D. Functions and mechanisms of redox regulation of cysteinebased phosphatases. Antioxid Redox Signal 2005 May;7(5-6):560-77.

(181) Claiborne A, Yeh JI, Mallett TC et al. Protein-sulfenic acids: diverse roles for an unlikely player in enzyme catalysis and redox regulation. Biochemistry 1999 November 23;38(47):15407-16.

(182) Poole LB, Karplus PA, Claiborne A. Protein sulfenic acids in redox signaling. Annu Rev Pharmacol Toxicol 2004;44:325-47.

(183) Barrett WC, DeGnore JP, Konig S et al. Regulation of PTP1B via glutathionylation of the active site cysteine 215. Biochemistry 1999 May 18;38(20):6699-705.

(184) Barrett WC, DeGnore JP, Konig S et al. Regulation of PTP1B via glutathionylation of the active site cysteine 215. Biochemistry 1999 May 18;38(20):6699-705.

(185) Barrett WC, DeGnore JP, Keng YF, Zhang ZY, Yim MB, Chock PB. Roles of superoxide radical anion in signal transduction mediated by reversible regulation of protein-tyrosine phosphatase 1B. J Biol Chem 1999 December 3;274(49):34543-6.

(186) Gravina SA, Mieyal JJ. Thioltransferase is a specific glutathionyl mixed disulfide oxidoreductase. Biochemistry 1993 April 6;32(13):3368-76.

(187) Starke DW, Chen Y, Bapna CP, Lesnefsky EJ, Mieyal JJ. Sensitivity of protein sulfhydryl repair enzymes to oxidative stress. Free Radic Biol Med 1997;23(3):373-84.

(188) Srinivasan U, Mieyal PA, Mieyal JJ. pH profiles indicative of rate-limiting nucleophilic displacement in thioltransferase catalysis. Biochemistry 1997 March 18;36(11):3199-206.

(189) Lee SR, Kwon KS, Kim SR, Rhee SG. Reversible inactivation of protein-tyrosine phosphatase 1B in A431 cells stimulated with epidermal growth factor. J Biol Chem 1998 June 19;273(25):15366-72. 
(190) Singh DK, Kumar D, Siddiqui Z, Basu SK, Kumar V, Rao KV. The strength of receptor signaling is centrally controlled through a cooperative loop between $\mathrm{Ca} 2+$ and an oxidant signal. Cell 2005 April 22;121(2):281-93.

(191) Meng TC, Fukada T, Tonks NK. Reversible oxidation and inactivation of protein tyrosine phosphatases in vivo. Mol Cell 2002 February;9(2):387-99.

(192) Tonks NK, Neel BG. Combinatorial control of the specificity of protein tyrosine phosphatases. Curr Opin Cell Biol 2001 April;13(2):182-95.

(193) Lee SR, Yang KS, Kwon J, Lee C, Jeong W, Rhee SG. Reversible inactivation of the tumor suppressor PTEN by H2O2. J Biol Chem 2002 June 7;277(23):20336-42.

(194) Lee SR, Yang KS, Kwon J, Lee C, Jeong W, Rhee SG. Reversible inactivation of the tumor suppressor PTEN by H2O2. J Biol Chem 2002 June 7;277(23):20336-42.

(195) Lee SR, Yang KS, Kwon J, Lee C, Jeong W, Rhee SG. Reversible inactivation of the tumor suppressor PTEN by H2O2. J Biol Chem 2002 June 7;277(23):20336-42.

(196) Ali IU, Schriml LM, Dean M. Mutational spectra of PTEN/MMAC1 gene: a tumor suppressor with lipid phosphatase activity. J Natl Cancer Inst 1999 November 17;91(22):1922-32.

(197) Stambolic V, Suzuki A, de la Pompa JL et al. Negative regulation of PKB/Aktdependent cell survival by the tumor suppressor PTEN. Cell 1998 October 2;95(1):29-39.

(198) Meng TC, Fukada T, Tonks NK. Reversible oxidation and inactivation of protein tyrosine phosphatases in vivo. Mol Cell 2002 February;9(2):387-99.

(199) Leslie NR, Downes CP. PTEN: The down side of PI 3-kinase signalling. Cell Signal 2002 April;14(4):285-95.

(200) Li DM, Sun H. PTEN/MMAC1/TEP1 suppresses the tumorigenicity and induces G1 cell cycle arrest in human glioblastoma cells. Proc Natl Acad Sci U S A 1998 December 22;95(26):15406-11.

(201) Guo Y, Sklar GN, Borkowski A, Kyprianou N. Loss of the cyclin-dependent kinase inhibitor p27(Kip1) protein in human prostate cancer correlates with tumor grade. Clin Cancer Res 1997 December;3(12 Pt 1):2269-74.

(202) Yang RM, Naitoh J, Murphy M et al. Low p27 expression predicts poor diseasefree survival in patients with prostate cancer. J Urol 1998 March;159(3):941-5.

(203) Tsihlias J, Kapusta LR, DeBoer G et al. Loss of cyclin-dependent kinase inhibitor p27Kip1 is a novel prognostic factor in localized human prostate adenocarcinoma.

Cancer Res 1998 February 1;58(3):542-8. 
(204) Cordon-Cardo C, Koff A, Drobnjak M et al. Distinct altered patterns of p27KIP1 gene expression in benign prostatic hyperplasia and prostatic carcinoma. J Natl Cancer Inst 1998 September 2;90(17):1284-91.

(205) Halvorsen OJ, Haukaas SA, Akslen LA. Combined loss of PTEN and p27 expression is associated with tumor cell proliferation by Ki-67 and increased risk of recurrent disease in localized prostate cancer. Clin Cancer Res 2003 April;9(4):1474-9.

(206) Nilsson I, Hoffmann I. Cell cycle regulation by the Cdc25 phosphatase family. Prog Cell Cycle Res 2000;4:107-14.

(207) Boutros R, Dozier C, Ducommun B. The when and wheres of CDC25 phosphatases. Curr Opin Cell Biol 2006 April;18(2):185-91.

(208) Iliakis G, Wang Y, Guan J, Wang H. DNA damage checkpoint control in cells exposed to ionizing radiation. Oncogene 2003 September 1;22(37):5834-47.

(209) Karlsson-Rosenthal C, Millar JB. Cdc25: mechanisms of checkpoint inhibition and recovery. Trends Cell Biol 2006 June;16(6):285-92.

(210) Kristjansdottir K, Rudolph J. Cdc25 phosphatases and cancer. Chem Biol 2004 August;11(8):1043-51.

(211) Rudolph J. Catalytic mechanism of Cdc25. Biochemistry 2002 December 10;41(49):14613-23.

(212) Rudolph J. Redox regulation of the Cdc25 phosphatases. Antioxid Redox Signal 2005 May;7(5-6):761-7.

(213) Savitsky PA, Finkel T. Redox regulation of Cdc25C. J Biol Chem 2002 June 7;277(23):20535-40.

(214) Baldin V, Theis-Febvre N, Benne C et al. PKB/Akt phosphorylates the CDC25B phosphatase and regulates its intracellular localisation. Biol Cell 2003 November;95(8):547-54.

(215) Fantl WJ, Muslin AJ, Kikuchi A et al. Activation of Raf-1 by 14-3-3 proteins. Nature 1994 October 13;371(6498):612-4.

(216) Reuther GW, Fu H, Cripe LD, Collier RJ, Pendergast AM. Association of the protein kinases c-Bcr and Bcr-Abl with proteins of the 14-3-3 family. Science 1994 October 7;266(5182):129-33.

(217) Conklin DS, Galaktionov K, Beach D. 14-3-3 proteins associate with cdc25 phosphatases. Proc Natl Acad Sci U S A 1995 August 15;92(17):7892-6. 
(218) Galaktionov K, Jessus C, Beach D. Raf1 interaction with Cdc25 phosphatase ties mitogenic signal transduction to cell cycle activation. Genes Dev 1995 May 1;9(9):104658.

(219) Xia K, Lee RS, Narsimhan RP, Mukhopadhyay NK, Neel BG, Roberts TM. Tyrosine phosphorylation of the proto-oncoprotein Raf-1 is regulated by Raf-1 itself and the phosphatase Cdc25A. Mol Cell Biol 1999 July;19(7):4819-24.

(220) Vogt A, Adachi T, Ducruet AP et al. Spatial analysis of key signaling proteins by high-content solid-phase cytometry in Hep3B cells treated with an inhibitor of Cdc25 dual-specificity phosphatases. J Biol Chem 2001 June 8;276(23):20544-50.

(221) Nemoto K, Vogt A, Oguri T, Lazo JS. Activation of the Raf-1/MEK/Erk kinase pathway by a novel Cdc25 inhibitor in human prostate cancer cells. Prostate 2004 January 1;58(1):95-102.

(222) Wang Z, Zhang B, Wang M, Carr BI. Cdc25A and ERK interaction: EGFRindependent ERK activation by a protein phosphatase Cdc25A inhibitor, compound 5. $J$ Cell Physiol 2005 August;204(2):437-44.

(223) Cui Y, Parra I, Zhang M et al. Elevated expression of mitogen-activated protein kinase phosphatase 3 in breast tumors: a mechanism of tamoxifen resistance. Cancer Res 2006 June 1;66(11):5950-9.

(224) Sun H, Charles CH, Lau LF, Tonks NK. MKP-1 (3CH134), an immediate early gene product, is a dual specificity phosphatase that dephosphorylates MAP kinase in vivo. Cell 1993 November 5;75(3):487-93.

(225) Charles CH, Sun H, Lau LF, Tonks NK. The growth factor-inducible immediateearly gene 3CH134 encodes a protein-tyrosine-phosphatase. Proc Natl Acad Sci U S A 1993 June 1;90(11):5292-6.

(226) Baas AS, Berk BC. Differential activation of mitogen-activated protein kinases by H2O 2 and O2- in vascular smooth muscle cells. Circ Res 1995 July;77(1):29-36.

(227) Alessi DR, Smythe C, Keyse SM. The human CL100 gene encodes a Tyr/Thrprotein phosphatase which potently and specifically inactivates MAP kinase and suppresses its activation by oncogenic ras in Xenopus oocyte extracts. Oncogene 1993 July;8(7):2015-20.

(228) Camps M, Nichols A, Arkinstall S. Dual specificity phosphatases: a gene family for control of MAP kinase function. FASEB J 2000 January;14(1):6-16.

(229) Cakir Y, Ballinger SW. Reactive species-mediated regulation of cell signaling and the cell cycle: the role of MAPK. Antioxid Redox Signal 2005 May;7(5-6):726-40.

(230) Seth D, Rudolph J. Redox regulation of MAP kinase phosphatase 3. Biochemistry 2006 July 18;45(28):8476-87. 
(231) Fritz G, Just I, Kaina B. Rho GTPases are over-expressed in human tumors. Int J Cancer 1999 May 31;81(5):682-7.

(232) Denoyelle C, Vasse M, Korner M et al. Cerivastatin, an inhibitor of HMG-CoA reductase, inhibits the signaling pathways involved in the invasiveness and metastatic properties of highly invasive breast cancer cell lines: an in vitro study. Carcinogenesis 2001 August;22(8):1139-48.

(233) Horiuchi A, Imai T, Wang C et al. Up-regulation of small GTPases, RhoA and $\mathrm{RhoC}$, is associated with tumor progression in ovarian carcinoma. Lab Invest 2003 June;83(6):861-70.

(234) A.M.Winter-Vann and G.L.Johnson. Integrated activation of MAP3Ks balances cell fate in response to stress. 102[4], 848-858. 2007. Journal of Cellular Biochemistry. Ref Type: Generic

(235) Yong Son Y-KCN-HKH-TCDGKaH-OP. Mitogen-Activated Protein Kinases and Reactive Oxygen Species: How Can ROS Activate MAPK Pathways?, vol. 2011, Article ID 792639, 6 pages, 2011. doi:10.1155/2011/792639. 2011, 6 pages. 2011. Journal of Signal Transduction.

Ref Type: Generic

(236) J.A.McCubrey MMLaRAF. Reactive oxygen species-induced activation of the MAP kinase signaling pathways. 8[9-10], 1775-1789. 2006. Antioxidants and Redox Signaling.

Ref Type: Generic

(237) M.Torres and H.J.Forman. Redox signaling and the MAP kinase pathways. 17[14], 287-296. 2003. BioFactors.

Ref Type: Generic

(238) A.Dabrowski CBMDITaAG. Reactive oxygen species activate mitogen-activated protein kinases in pancreatic acinar cells. 21[4], 376-384. 2000. Pancreas.

Ref Type: Generic

(239) J.Ruffels MGaJMD. ,Activation of ERK1/2, JNK and PKB by hydrogen peroxide in human SH-SY5Y neuroblastoma cells: role of ERK1/2 in H2O2-induced cell death. 483[2-3], 163-173. 2004. European Journal of Pharmacology. Ref Type: Generic

(240) Domann FEJ, Levy JPFJSaBGT. Constitutive AP-1 DNA binding and transactivating ability of malignant but not benign mouse epidermal cells. 9, 61-66. 1994. Mol. Carcinog.

Ref Type: Generic

(241) Dong Z, Birrer MJWRGMLMaCNH. Blocking of tumor promoter-induced AP-1 activity inhibits induced transformation in JB6 mouse epidermal cells. 91, 609-613. 1994. 
USA, Proc. Natl Acad. Sci.

Ref Type: Generic

(242) Dong Z, Crawford HCLVTDWRMLMaCNH. A dominant negative mutant of jun blocking 12-O-tetradecanoylphorbol-13-acetate-induced invasion in mouse keratinocytes. 19, 204-212. 2011. Mol. Carcinog.

Ref Type: Generic

(243) Li JJ, Dong ZDMIaCNH. Inhibition of tumor promoter-induced transformation by retinoids that transrepress AP-1 without transactivating retinoic acid response element... 56, 483-489. 1996. Cancer Res.

Ref Type: Generic

(244) Domann FE, Levy JPBMJaBGT. Stable expression of a c-Jun deletion mutant in two malignant mouse epidermal cell lines blocks tumor formation in nude mice. [5], 916. 1994. Cell Growth Differ.

Ref Type: Generic

(245) Baeuerle PAaBD. NF-kappaB: ten years after. Cell. [87], 13-20. 1996.

Ref Type: Generic

(246) Li JJ, Westergaard CGPaCNH. Inhibitors of both nuclear factor-kappaB and activator protein-1 activation block the neoplastic transformation response. Cancer Res. 57, 3569-3576. 1997.

Ref Type: Generic

(247) Li JJ, Rhim JSSRVKHaCNH. Expression of dominant negative Jun inhibits elevated AP-1 and NF-kappaB transactivation and suppresses anchorage independent growth of HPV immortalized human keratinocytes. Oncogene. 16, 2711-2721. 1998. Ref Type: Generic

(248) Ashok Gupta SFRaGTB. Increased ROS levels contribute to elevated transcription factor and MAP kinase activities in malignantly progressed mouse keratinocyte cell lines. 20[11], 2063-2073. 1999. Carcinogenesis.

Ref Type: Generic

(249) Flohe L, Brigelius-Flohe RSCTMGaPL. Redox regulation of NF-kappa B activation. 22, 1115-1126. 1997. Free Radic. Biol. Med.

Ref Type: Generic

(250) Schreck R, B.Meier DAMnWDgaPAB. Dithiocarbamates as potent inhibitors of nuclear factor kB activation in intact cells. 175, 1181. 1992. J. Exp. Med.

Ref Type: Generic

(251) Schreck.R. PRaPAB. Reactive oxygen intermediatesas apparently widely used messengers in the activation of the NF-kB transcriptionfactor and HIV-1. 10, 2247. 1991. EMBO J.

Ref Type: Generic 
(252) Abate C. Redox regulation of fos and jun DNA-binding activity in vitro. Science. Patel LRFJIaCT, editor. 249, 1157-1161. 1990.

Ref Type: Generic

(253) Karin M., Takahashi T KPDMCYMCRDBVNGGFLN. Oxidative stress and gene expression: the AP-1 and NF-B connections. 15, 87-89. 2001. Biofactors.

Ref Type: Generic

(254) Angel P KM. The role of Jun Fos and the AP-1 complex in cell proliferation and transformation. [1072], 129-157. 1991. Biochim Biophys Acta.

Ref Type: Generic

(255) Wang XMJLLYaHNJ. The cellular response to oxidative stress: influences of mitogen-activated protein kinase signalling pathways on cell survival. 333, 291-300. 1998. Biochem. J.

Ref Type: Generic

(256) Xia ZDMRJDRJaGME. Opposing effects of ERK and JNK-p38 MAP kinases on apoptosis. . 270, 1326-1331. 1995. Science.

Ref Type: Generic

(257) Karin M. The regulation of AP-1 activity by mitogen-activated protein kinases. 270, 16483-16486. 1999. J. Biol. Chem.

Ref Type: Generic

(258) Lee FSHJCZJaMT. Activation of the IkappaB alpha kinase complex by MEKK1, a kinase of the JNK pathway. 213-222. 1997. Cell.

Ref Type: Generic

(259) Schwenger PADSEYaVJ. Activation of p38 mitogen-activated protein kinase by sodium salicylate leads to inhibition of tumor necrosis factor-induced IkappaB alpha phosphorylation and degradation. 18, 78-84. 1998. Mol. Cell Biol.

Ref Type: Generic

(260) Guyton KZLYGMXQaHNJ. Activation of mitogen-activated protein kinase by H2O2. Role in cell survival following oxidant injury. . 271, 4138-4142. 1996. J. Biol.

Chem.

Ref Type: Generic

(261) NRF1 nuclear respiratory factor 1. 12-9-2007.

Ref Type: Generic

(262) Suliman HB, Carraway MS, Welty-Wolf KE, Whorton AR, Piantadosi CA. Lipopolysaccharide stimulates mitochondrial biogenesis via activation of nuclear respiratory factor-1. J Biol Chem 2003 October 17;278(42):41510-8. 
(263) Evans MJ, Scarpulla RC. Interaction of nuclear factors with multiple sites in the somatic cytochrome c promoter. Characterization of upstream NRF-1, ATF, and intron Sp1 recognition sequences. J Biol Chem 1989 August 25;264(24):14361-8.

(264) Evans MJ, Scarpulla RC. NRF-1: a trans-activator of nuclear-encoded respiratory genes in animal cells. Genes Dev 1990 June;4(6):1023-34.

(265) Virbasius CA, Virbasius JV, Scarpulla RC. NRF-1, an activator involved in nuclear-mitochondrial interactions, utilizes a new DNA-binding domain conserved in a family of developmental regulators. Genes Dev 1993 December;7(12A):2431-45.

(266) Braidotti G, Borthwick IA, May BK. Identification of regulatory sequences in the gene for 5-aminolevulinate synthase from rat. J Biol Chem 1993 January 15;268(2):110917.

(267) Evans MJ, Scarpulla RC. NRF-1: a trans-activator of nuclear-encoded respiratory genes in animal cells. Genes Dev 1990 June;4(6):1023-34.

(268) Virbasius JV, Scarpulla RC. Activation of the human mitochondrial transcription factor A gene by nuclear respiratory factors: a potential regulatory link between nuclear and mitochondrial gene expression in organelle biogenesis. Proc Natl Acad Sci U S A 1994 February 15;91(4):1309-13.

(269) Wasserman WW, Fahl WE. Functional antioxidant responsive elements. Proc Natl Acad Sci U S A 1997 May 13;94(10):5361-6.

(270) Prestera T, Talalay P, Alam J, Ahn YI, Lee PJ, Choi AM. Parallel induction of heme oxygenase- 1 and chemoprotective phase 2 enzymes by electrophiles and antioxidants: regulation by upstream antioxidant-responsive elements (ARE). Mol Med 1995 November;1(7):827-37.

(271) Venugopal R, Jaiswal AK. Nrf2 and Nrf1 in association with Jun proteins regulate antioxidant response element-mediated expression and coordinated induction of genes encoding detoxifying enzymes. Oncogene 1998 December 17;17(24):3145-56.

(272) Venugopal R, Jaiswal AK. Nrf1 and Nrf2 positively and c-Fos and Fra1 negatively regulate the human antioxidant response element-mediated expression of NAD(P)H:quinone oxidoreductase1 gene. Proc Natl Acad Sci U S A 1996 December 10;93(25):14960-5.

(273) Novotny V, Prieschl EE, Csonga R, Fabjani G, Baumruker T. Nrf1 in a complex with fosB, c-jun, junD and ATF2 forms the AP1 component at the TNF alpha promoter in stimulated mast cells. Nucleic Acids Res 1998 December 1;26(23):5480-5.

(274) Farmer SC, Sun CW, Winnier GE, Hogan BL, Townes TM. The bZIP transcription factor LCR-F1 is essential for mesoderm formation in mouse development. Genes Dev 1997 March 15;11(6):786-98. 
(275) Chan JY, Kwong M, Lu R et al. Targeted disruption of the ubiquitous CNC-bZIP transcription factor, Nrf-1, results in anemia and embryonic lethality in mice. EMBOJ 1998 March 16;17(6):1779-87.

(276) Chang WT, Chen HI, Chiou RJ, Chen CY, Huang AM. A novel function of transcription factor alpha-Pal/NRF-1: increasing neurite outgrowth. Biochem Biophys Res Commun 2005 August 19;334(1):199-206.

(277) Gugneja S, Scarpulla RC. Serine phosphorylation within a concise amino-terminal domain in nuclear respiratory factor 1 enhances DNA binding. J Biol Chem 1997 July 25;272(30):18732-9.

(278) Herzig RP, Scacco S, Scarpulla RC. Sequential serum-dependent activation of CREB and NRF-1 leads to enhanced mitochondrial respiration through the induction of cytochrome c. J Biol Chem 2000 April 28;275(17):13134-41.

(279) Izumi H, Ohta R, Nagatani G et al. p300/CBP-associated factor (P/CAF) interacts with nuclear respiratory factor-1 to regulate the UDP-N-acetyl-alpha-d-galactosamine: polypeptide $\mathrm{N}$-acetylgalactosaminyltransferase-3 gene. Biochem J 2003 August 1;373(Pt 3):713-22.

(280) Choi YS, Kim S, Kyu LH, Lee KU, Pak YK. In vitro methylation of nuclear respiratory factor- 1 binding site suppresses the promoter activity of mitochondrial transcription factor A. Biochem Biophys Res Commun 2004 January 30;314(1):118-22.

(281) Kumari D, Usdin K. Interaction of the transcription factors USF1, USF2, and alpha -Pal/Nrf-1 with the FMR1 promoter. Implications for Fragile X mental retardation syndrome. J Biol Chem 2001 February 9;276(6):4357-64.

(282) Narayanan K, Ramachandran A, Peterson MC et al. The CCAAT enhancer-binding protein (C/EBP)beta and Nrf1 interact to regulate dentin sialophosphoprotein (DSPP) gene expression during odontoblast differentiation. J Biol Chem 2004 October 29;279(44):45423-32.

(283) Scarpulla RC. Nuclear activators and coactivators in mammalian mitochondrial biogenesis. Biochim Biophys Acta 2002 June 7;1576(1-2):1-14.

(284) Stirone C, Duckles SP, Krause DN, Procaccio V. Estrogen increases mitochondrial efficiency and reduces oxidative stress in cerebral blood vessels. Mol Pharmacol 2005 October;68(4):959-65.

(285) Rodriguez-Cuenca S, Monjo M, Gianotti M, Proenza AM, Roca P. Expression of mitochondrial biogenesis-signaling factors in brown adipocytes is influenced specifically by 17beta-estradiol, testosterone, and progesterone. Am J Physiol Endocrinol Metab 2007 January;292(1):E340-E346. 
(286) Llado I, Rodriguez-Cuenca S, Pujol E et al. Gender effects on adrenergic receptor expression and lipolysis in white adipose tissue of rats. Obes Res 2002 April;10(4):296305.

(287) Guzeloglu-Kayisli O, Kayisli UA, Al-Rejjal R, Zheng W, Luleci G, Arici A. Regulation of PTEN (phosphatase and tensin homolog deleted on chromosome 10) expression by estradiol and progesterone in human endometrium. J Clin Endocrinol Metab 2003 October;88(10):5017-26.

(288) Felty Q, Xiong WC, Sun D et al. Estrogen-induced mitochondrial reactive oxygen species as signal-transducing messengers. Biochemistry 2005 May 10;44(18):6900-9.

(289) Felty Q, Xiong WC, Sun D et al. Estrogen-induced mitochondrial reactive oxygen species as signal-transducing messengers. Biochemistry 2005 May 10;44(18):6900-9.

(290) Xu Z, Chen L, Leung L, Yen TS, Lee C, Chan JY. Liver-specific inactivation of the Nrfl gene in adult mouse leads to nonalcoholic steatohepatitis and hepatic neoplasia. Proc Natl Acad Sci U S A 2005 March 15;102(11):4120-5.

(291) Tokusumi Y, Zhou S, Takada S. Nuclear respiratory factor 1 plays an essential role in transcriptional initiation from the hepatitis B virus x gene promoter. J Virol 2004 October;78(20):10856-64.

(292) Tokusumi Y, Zhou S, Takada S. Nuclear respiratory factor 1 plays an essential role in transcriptional initiation from the hepatitis B virus x gene promoter. J Virol 2004 October;78(20):10856-64.

(293) auf dem KU, Huber M, Beyer TA et al. Nrf transcription factors in keratinocytes are essential for skin tumor prevention but not for wound healing. Mol Cell Biol 2006 May;26(10):3773-84.

(294) Herzig RP, Scacco S, Scarpulla RC. Sequential serum-dependent activation of CREB and NRF-1 leads to enhanced mitochondrial respiration through the induction of cytochrome c. J Biol Chem 2000 April 28;275(17):13134-41.

(295) Cam H, Balciunaite E, Blais A et al. A common set of gene regulatory networks links metabolism and growth inhibition. Mol Cell 2004 November 5;16(3):399-411.

(296) Herzig RP, Scacco S, Scarpulla RC. Sequential serum-dependent activation of CREB and NRF-1 leads to enhanced mitochondrial respiration through the induction of cytochrome c. J Biol Chem 2000 April 28;275(17):13134-41.

(297) Virbasius CA, Virbasius JV, Scarpulla RC. NRF-1, an activator involved in nuclear-mitochondrial interactions, utilizes a new DNA-binding domain conserved in a family of developmental regulators. Genes Dev 1993 December;7(12A):2431-45. 
(298) Virbasius CA, Virbasius JV, Scarpulla RC. NRF-1, an activator involved in nuclear-mitochondrial interactions, utilizes a new DNA-binding domain conserved in a family of developmental regulators. Genes Dev 1993 December;7(12A):2431-45.

(299) Morrish F, Giedt C, Hockenbery D. c-MYC apoptotic function is mediated by NRF-1 target genes. Genes Dev 2003 January 15;17(2):240-55.

(300) Felty Q, Singh KP, Roy D. Estrogen-induced G1/S transition of G0-arrested estrogen-dependent breast cancer cells is regulated by mitochondrial oxidant signaling. Oncogene 2005 July 21;24(31):4883-93.

(301) Kanda N, Watanabe S. 17beta-estradiol stimulates the growth of human keratinocytes by inducing cyclin D2 expression. J Invest Dermatol 2004 August;123(2):319-28.

(302) Liu Y, Ludes-Meyers J, Zhang Y et al. Inhibition of AP-1 transcription factor causes blockade of multiple signal transduction pathways and inhibits breast cancer growth. Oncogene 2002 October 31;21(50):7680-9.

(303) Felty Q, Xiong WC, Sun D et al. Estrogen-induced mitochondrial reactive oxygen species as signal-transducing messengers. Biochemistry 2005 May 10;44(18):6900-9.

(304) Piantadosi CA, Suliman HB. Mitochondrial transcription factor A induction by redox activation of nuclear respiratory factor $1 . J$ Biol Chem 2006 January 6;281(1):32433.

(305) Miranda S, Foncea R, Guerrero J, Leighton F. Oxidative stress and upregulation of mitochondrial biogenesis genes in mitochondrial DNA-depleted HeLa cells. Biochem Biophys Res Commun 1999 April 29;258(1):44-9.

(306) Kwong M, Kan YW, Chan JY. The CNC basic leucine zipper factor, Nrfl, is essential for cell survival in response to oxidative stress-inducing agents. Role for Nrfl in gamma-gcs(l) and gss expression in mouse fibroblasts. J Biol Chem 1999 December 24;274(52):37491-8.

(307) Chen L, Kwong M, Lu R et al. Nrf1 is critical for redox balance and survival of liver cells during development. Mol Cell Biol 2003 July;23(13):4673-86.

(308) Sherr CJ. Cancer cell cycles. Science 1996 December 6;274(5293):1672-7.

(309) Pearce AK, Humphrey TC. Integrating stress-response and cell-cycle checkpoint pathways. Trends Cell Biol 2001 October;11(10):426-33.

(310) Sherr CJ, Roberts JM. Inhibitors of mammalian G1 cyclin-dependent kinases. Genes Dev 1995 May 15;9(10):1149-63.

(311) Gibbs E, Kelman Z, Gulbis JM et al. The influence of the proliferating cell nuclear antigen-interacting domain of p21(CIP1) on DNA synthesis catalyzed by the human and 
Saccharomyces cerevisiae polymerase delta holoenzymes. J Biol Chem 1997 January 24;272(4):2373-81.

(312) Li JM, Brooks G. Cell cycle regulatory molecules (cyclins, cyclin-dependent kinases and cyclin-dependent kinase inhibitors) and the cardiovascular system; potential targets for therapy? Eur Heart $J 1999$ March;20(6):406-20.

(313) Blain SW, Scher HI, Cordon-Cardo C, Koff A. p27 as a target for cancer therapeutics. Cancer Cell 2003 February;3(2):111-5.

(314) Caldon CE, Daly RJ, Sutherland RL, Musgrove EA. Cell cycle control in breast cancer cells. J Cell Biochem 2006 February 1;97(2):261-74.

(315) Medema RH, Kops GJ, Bos JL, Burgering BM. AFX-like Forkhead transcription factors mediate cell-cycle regulation by Ras and PKB through p27kip1. Nature 2000 April 13;404(6779):782-7.

(316) Sherr CJ, Roberts JM. CDK inhibitors: positive and negative regulators of G1phase progression. Genes Dev 1999 June 15;13(12):1501-12.

(317) Liang J, Slingerland JM. Multiple roles of the PI3K/PKB (Akt) pathway in cell cycle progression. Cell Cycle 2003 July;2(4):339-45.

(318) Boehm M, Yoshimoto T, Crook MF et al. A growth factor-dependent nuclear kinase phosphorylates p27(Kip1) and regulates cell cycle progression. EMBO J 2002 July 1;21(13):3390-401.

(319) Kerkhoff E, Rapp UR. Induction of cell proliferation in quiescent NIH 3T3 cells by oncogenic c-Raf-1. Mol Cell Biol 1997 May;17(5):2576-86.

(320) Rivard N, Boucher MJ, Asselin C, L'Allemain G. MAP kinase cascade is required for p27 downregulation and S phase entry in fibroblasts and epithelial cells. Am J Physiol 1999 October;277(4 Pt 1):C652-C664.

(321) Delmas C, Manenti S, Boudjelal A, Peyssonnaux C, Eychene A, Darbon JM. The p42/p44 mitogen-activated protein kinase activation triggers p27Kip1 degradation independently of CDK2/cyclin E in NIH 3T3 cells. J Biol Chem 2001 September 14;276(37):34958-65.

(322) Kortylewski M, Heinrich PC, Kauffmann ME, Bohm M, Mackiewicz A, Behrmann I. Mitogen-activated protein kinases control p27/Kip1 expression and growth of human melanoma cells. Biochem J 2001 July 1;357(Pt 1):297-303.

(323) Foster JS, Fernando RI, Ishida N, Nakayama KI, Wimalasena J. Estrogens downregulate p27Kip1 in breast cancer cells through Skp2 and through nuclear export mediated by the ERK pathway. $J$ Biol Chem 2003 October 17;278(42):41355-66. 
(324) Bhatt KV, Spofford LS, Aram G, McMullen M, Pumiglia K, Aplin AE. Adhesion control of cyclin D1 and p27Kip1 levels is deregulated in melanoma cells through BRAF-MEK-ERK signaling. Oncogene 2005 May 12;24(21):3459-71.

(325) Tessema M, Lehmann U, Kreipe H. Cell cycle and no end. Virchows Arch 2004 April;444(4):313-23.

(326) Martinez MC, Post JA, Verkleij AJ, Verrips CT, Boonstra J. The effect of hydrogen peroxide on the cyclin D expression in fibroblasts. Cell Mol Life Sci 2001 June;58(7):990-6.

(327) Wartenberg M, Diedershagen H, Hescheler J, Sauer H. Growth stimulation versus induction of cell quiescence by hydrogen peroxide in prostate tumor spheroids is encoded by the duration of the $\mathrm{Ca}(2+)$ response. J Biol Chem 1999 September 24;274(39):2775967.

(328) Arnold RS, Shi J, Murad E et al. Hydrogen peroxide mediates the cell growth and transformation caused by the mitogenic oxidase Nox1. Proc Natl Acad Sci U S A 2001 May 8;98(10):5550-5.

(329) Menon SG, Sarsour EH, Spitz DR et al. Redox regulation of the G1 to S phase transition in the mouse embryo fibroblast cell cycle. Cancer Res 2003 May 1;63(9):210917.

(330) Djelloul S, Tarunina M, Barnouin K, Mackay A, Jat PS. Differential protein expression, DNA binding and interaction with SV40 large tumour antigen implicate the p63-family of proteins in replicative senescence. Oncogene 2002 February 7;21(7):981-9.

(331) Dijkers PF, Medema RH, Pals C et al. Forkhead transcription factor FKHR-L1 modulates cytokine-dependent transcriptional regulation of p27(KIP1). Mol Cell Biol 2000 December;20(24):9138-48.

(332) Radisavljevic ZM, Gonzalez-Flecha B. Signaling through Cdk2, importin-alpha and NuMA is required for $\mathrm{H} 2 \mathrm{O} 2$-induced mitosis in primary type II pneumocytes. Biochim Biophys Acta 2003 May 12;1640(2-3):163-70.

(333) Nigg EA. Mitotic kinases as regulators of cell division and its checkpoints. Nat Rev Mol Cell Biol 2001 January;2(1):21-32.

(334) Horne MM, Guadagno TM. A requirement for MAP kinase in the assembly and maintenance of the mitotic spindle. J Cell Biol 2003 June 23;161(6):1021-8.

(335) Bartkova J, Rezaei N, Liontos M et al. Oncogene-induced senescence is part of the tumorigenesis barrier imposed by DNA damage checkpoints. 444, 633-637. 2006. Nature.

Ref Type: Generic 
(336) Di Micco R, Fumagalli M, Cicalese A et al. Oncogene-induced senescence is a DNA damage response triggered by DNA hyper-replication. 444, 638-642. 2006. Nature. Ref Type: Generic

(337) Pelicano H, Xu RH, Du M et al. Mitochondrial respiration defects in cancer cells cause activation of Akt survival pathway through a redox-mediated mechanism. 175, 913-923. 2006. J. Cell Biol.

Ref Type: Generic

(338) William C.Burhans NHH. The cell cycle is a redox cycle: Linking phase-speci?c targets to cell fate. 47, 1282-1293. 2009. Free Radical Biology \& Medicine.

Ref Type: Generic

(339) XIANGHONG ZOU TTDRJFBHIDSUAHK. The Cell Cycle-Regulatory CDC25A Phosphatase Inhibits Apoptosis Signal-Regulating Kinase 1. 21[14], 4818-4828. 2001. MOLECULAR AND CELLULAR BIOLOGY.

Ref Type: Generic

(340) Jones RG, Thompson CB. Tumor suppressors and cellmetabolism: a recipe for cancer growth. 23, 537-548. 2009. Genes Dev.

Ref Type: Generic

(341) Dang CV, Kim JW, Gao P, Yustein J. The interplay between MYC and HIF incancer. 8, 51-56. 2008. Nat. Rev. Cancer.

Ref Type: Generic

\section{Acknowledgments}

The Department of the Defense BCRP-funded project W81XWH-07-1-0417, BC060125, provided funding for this research. 


\section{Figures and Legend}

\section{Figure1-R}

$$
\begin{aligned}
& \text { Thiolate }_{-\mathrm{SH}}^{-\mathrm{S}^{-}}+\mathrm{H}_{2} \mathrm{O}_{2} \rightleftharpoons \underset{-\mathrm{SH}}{\text { Sulfenate }} \stackrel{\mathrm{SO}^{-}}{\longrightarrow}+\mathrm{H}_{2} \mathrm{O}+\mathrm{H}^{+} \ldots \text { (A) } \\
& \text { Sulfenate }_{-\mathrm{SH}}^{-\mathrm{SO}^{-}}+\text {Thiol }_{-\mathrm{SH}}^{\longrightarrow} \underset{\substack{\text { Inter molecular } \\
\text { disulfide bond }}}{-\mathrm{SH}-\mathrm{S}-}+\mathrm{OH} \quad \ldots \text { (B) } \\
& \begin{array}{l}
-\mathrm{S}-\mathrm{S}-\mathrm{SH} \\
\begin{array}{l}
\text { Inter molecular } \\
\text { disulfide bond }
\end{array}
\end{array}
\end{aligned}
$$

Redox reactions involving hydrogen peroxide $\left(\mathrm{H}_{2} \mathrm{O}_{2}\right)$ and a thiolate $\left(\mathbf{R S}^{-}\right)$. Thiolate reacts easily with $\mathrm{H}_{2} \mathrm{O}_{2}$ forming a sulfenate $\left(\mathrm{RSO}^{-}\right)$(see $1 \mathrm{~A}$ ), the sulfenate that is formed then reacts with a thiol to form a disulphide bond (see 1B). Then the original thiolate is restored by exchange with another thiolate (see 1C).

\section{Figure 2-R}
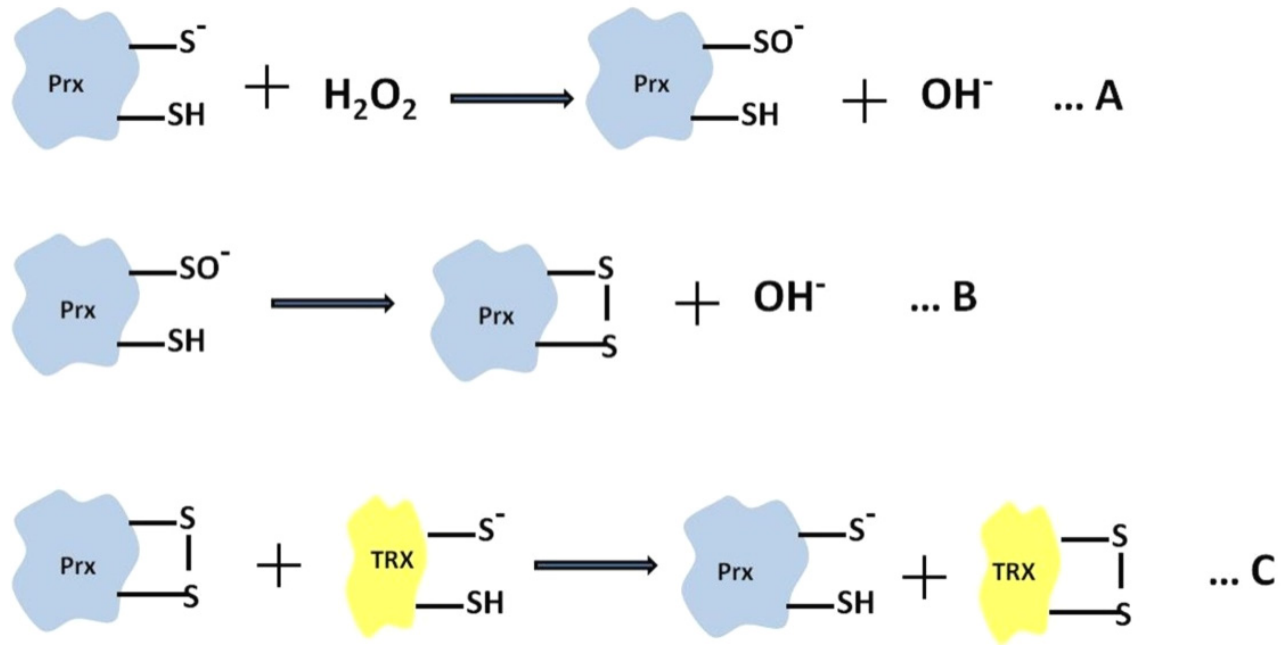
The oxidation of Prx by $\mathrm{H}_{2} \mathrm{O}_{2}$. Prx reacts with $\mathrm{H}_{2} \mathrm{O}_{2}$ to form a sulfenate (fig.2A). A second thiol then reacts with the sulfenate to form an intra-molecular disulphide (fig.2 B). In the third and final step, TRX used to restore the original thiolate (fig. 2C).

\section{Figure 3-R}

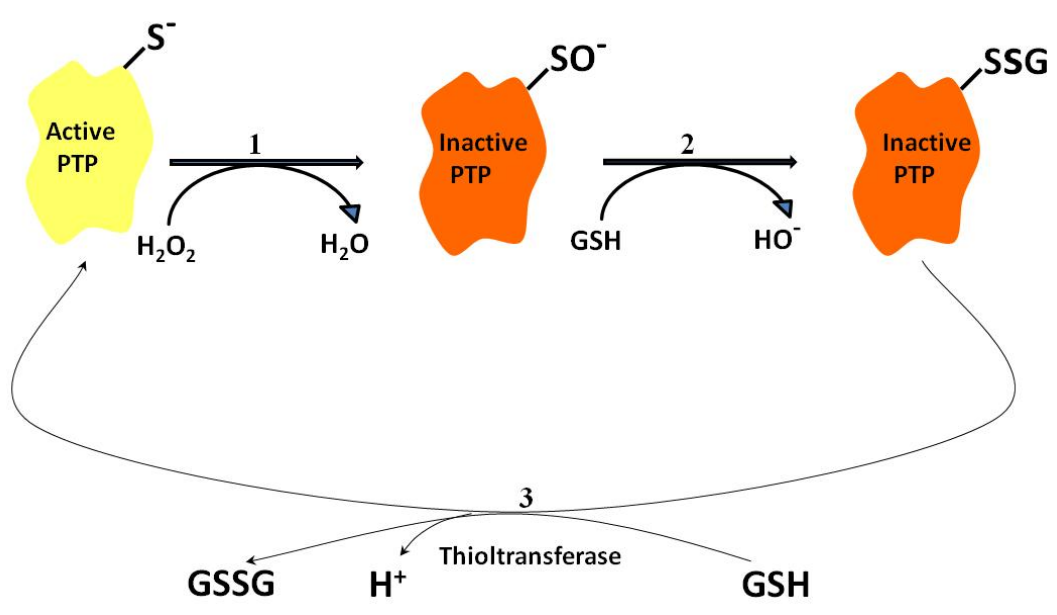

Reversible PTP inactivation by $\mathbf{H}_{2} \mathbf{O}_{2}$. In step 1, an active PTP containing a thiolate reacts with $\mathrm{H}_{2} \mathrm{O}_{2}$ to form an inactive but reversible PTP-sulfenate ( $\left.\mathrm{SO}^{-}\right)$. In step 2, the PTP-sulfenate reacts with GSH within the cell to form a mixed disulfide bond which would prevent irreversible oxidation of the active site cysteine and allow for the reversible reduction. In step 3, the mixed disulfide bond on the inactive PTP is reversed back to a thiolate and PTP becomes active again. 


\section{Figure 4-R}

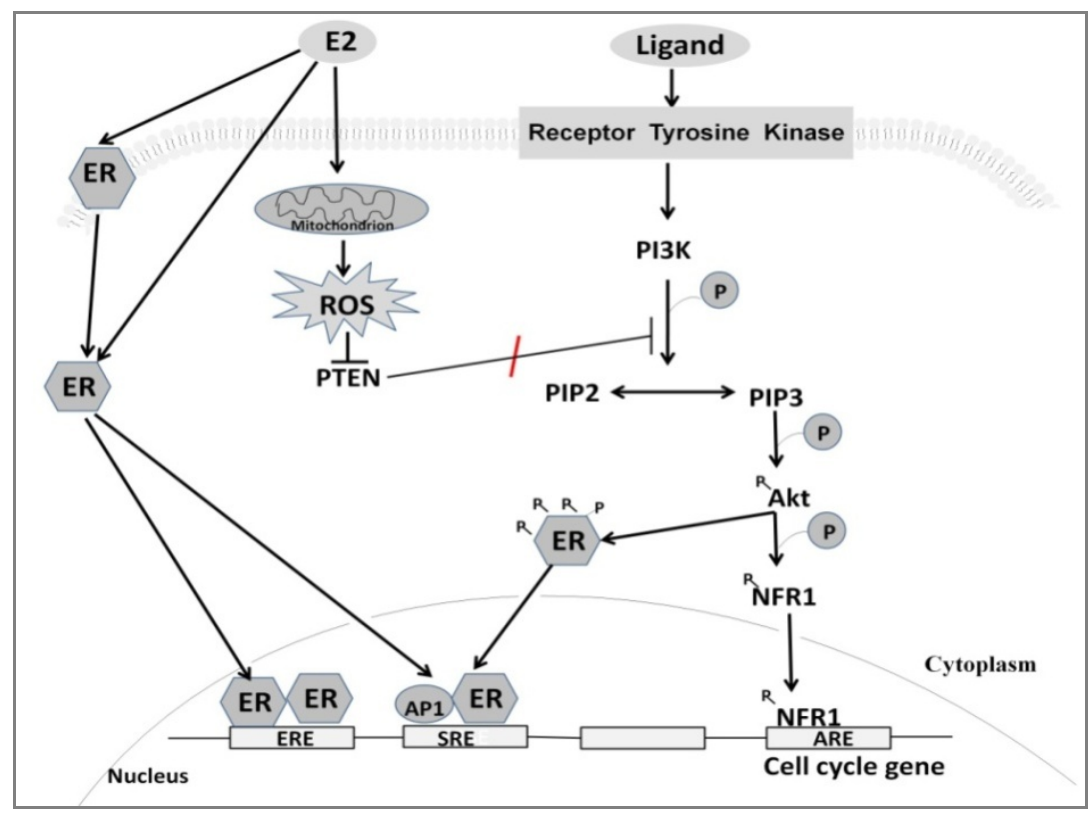

The effect of E2-induced ROS on regular mitogenic signaling. E2 crosses the cell membrane and goes to the mitochondrium where it induces ROS formation. The oxidants formed inhibit PTEN rendering it unable to inhibit the PI3K/Akt pathway resulting in the hyper-stimulation of the pathway and a continuous phosphorylation of Akt. Phosphorylated Akt then activates NRF-1 by phosphorylation enabling the now active protein to binds to the promoter region of certain cell cycle genes. 
Figure 5-R

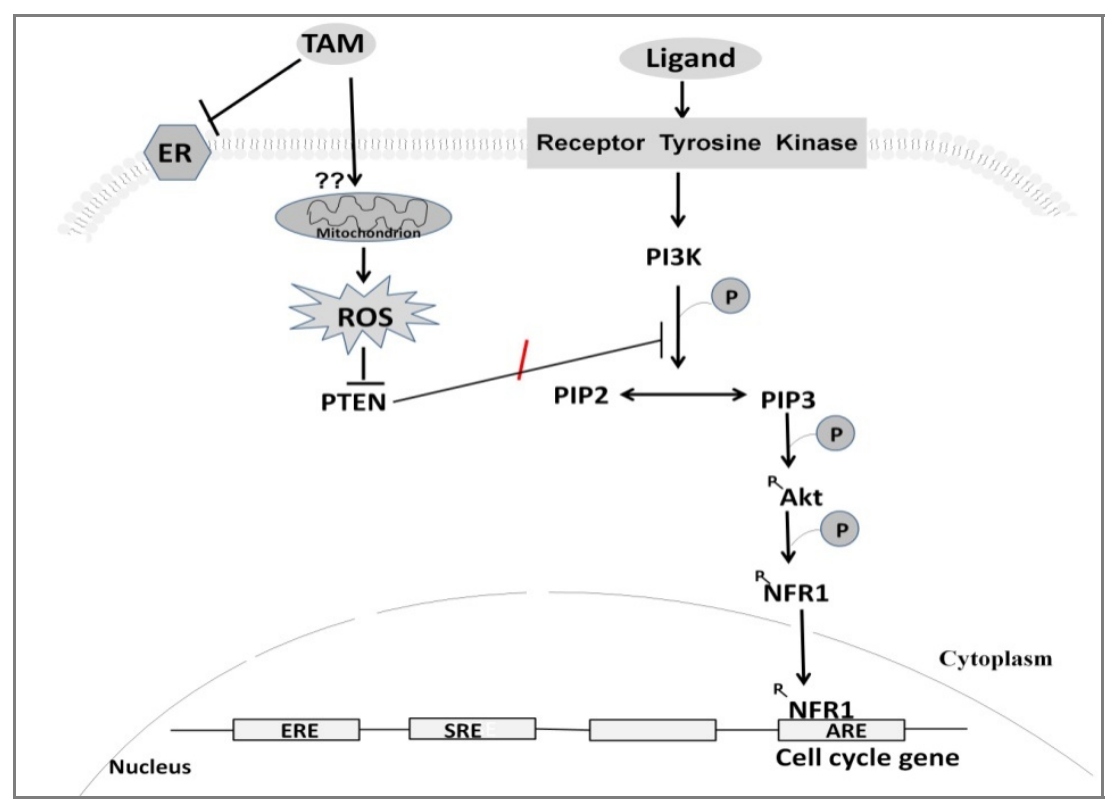

The effect of tamoxifen-induced ROS on regular mitogenic signaling. Tamoxifeninduced oxidants inhibit PTEN rendering it unable to inhibit the PI3K/Akt pathway resulting in the hyper-stimulation of the pathway and a continuous phosphorylation of Akt. Phosphorylated Akt then activates NRF-1 by phosphorylation enabling the now active protein to binds to the promoter region of certain cell cycle genes.

\title{
III REDOX SIGNALING CONRIBUTES TO THE DEVELOPMENT OF TAMOXIFEN RESISTANCE IN BREAST CANCER TREATMENT
}

\begin{abstract}
Tamoxifen is a selective estrogen receptor modulator (SERM) which is used to treat estrogen receptor positive $(\mathrm{ER}+)$ breast cancer. It is also used in breast cancer prevention
\end{abstract}


and as an adjuvant in early breast cancer cases. Only about $70 \%$ of breast cancer patients will initially respond to tamoxifen treatment. About $40 \%$ of patients who were initially responsive to the drug and majority of the patients with metastatic breast disease will develop resistance over time. Therefore the problem of tamoxifen resistance has been a major setback in the otherwise successful treatment of ER+ breast cancer patients. Although there has been an improvement in our current understanding of the molecular mechanism(s) that result in the development of tamoxifen resistance, there is still a lot of ground to cover on the subject. In this study we explored the role of Reactive oxygen species (ROS) in the evolution of tamoxifen sensitive breast cancer to tamoxifen resistant breast cancer. ROS are products of cellular metabolism which have been shown to induce oxidative stress. An excessive and/or sustained increase in ROS production has been implicated in the pathogenesis of cancer. Furthermore, ROS induced oxidative stress has been shown to initiate various cellular responses including cell proliferation and transformation; alteration of intracellular redox state and the oxidative modification of certain signaling proteins resulting in the post translational modification of their downstream targets. Interestingly, like estrogen, tamoxifen has been shown to induce ROS formation, making it probable that tamoxifen induced ROS generated as a result of prolong tamoxifen treatment of breast cancer patients may play a vital role in the development of its resistance. Using tamoxifen resistant LCC2 cell and standard laboratory techniques, we examined the role of ROS in the evolution of breast cancer from a tamoxifen sensitive phenotype to a resistant one. We were interested in finding out how and if ROS induces the post translational modification of p27 resulting in the loss of its inhibitory function and if this process can be reversed by pre-exposing the cells 
to biological or chemical antioxidants. We discovered that, as a result of tamoxifen exposure, an increasingly pro-oxidant environment induced cell proliferation by diminishing p27 expression and increasing its phosphorylation on Threonine157 and Threonine187. This is accompanied by an ensuing reduction of p27 binding to Cyclin E/Cdk2 complex and loss of p27 stability culminating in the loss of sensitivity to tamoxifen. We also found that Pre-exposing cells to either biological or chemical antioxidants, restored tamoxifen sensitivity by reversing the previous expression and phosphorylation of $\mathrm{p} 27$.

\section{Introduction}

Tamoxifen resistance has remained a major setback in an otherwise successful treatment of estrogen receptor positive $(\mathrm{ER}+)$ breast cancer. Most breast cancers are estrogenreceptor positive $(\mathrm{ER}+)$. Approximately $70 \%$ of patients with $\mathrm{ER}+$ cancer will respond to anti-estrogen therapy, such as tamoxifen ${ }^{1}$. In addition, a significant number of tumors that initially respond to tamoxifen treatment often progress into a resistant phenotype over time, in spite of sustained expression of $\mathrm{ER} \alpha^{2,3}$.

Over the years, several pathways and postulates have been proposed and examined as possible mechanisms of breast cancer resistance to tamoxifen. While some of these have translated into beneficial therapies to a large number of patients, tamoxifen resistance still remains a significant problem. In addition, though studies have examined the roles of $\mathrm{ER} \alpha$ and $\beta$, and their co-regulatory proteins; growth factor receptors and the activity of their downstream kinases; Cas/c-Src/BCAR3 and cell cycle regulators like Cyclins D/E 
and p27, currently there is no study investigating the effect of Reactive oxygen species (ROS) on p27 in tamoxifen resistance.

Cancers have been shown to be under persistent oxidative stress ${ }^{4}$. Oxidative stress, which is triggered by an imbalance between the production and detoxification of ROS, ${ }^{5}$ has been implicated in the therapeutic resistance to tamoxifen ${ }^{6}$. Tamoxifen, a selective estrogen receptor modulator (SERM), has been reported to possess both pro- and antioxidant properties. Among its antioxidant actions are: its cardio-protective effect in the prevention of atherosclerosis ${ }^{7,8}$; its inhibition of lipid peroxidation ${ }^{9}$ and its ability to protect low density lipoproteins (LDL) against copper ion-mediated oxidative damage ${ }^{10}$ in humans. Conversely, its pro-oxidant effects include its ability to induce oxidative liver damage ${ }^{11}$ and its explication as a hepato-carcinogen in rodents due to ROS overproduction that occurs during its metabolism ${ }^{12,13}$. Additionally, it has been suggested that oxidative stress might trigger the pathogenesis of tamoxifen-induced toxicity ${ }^{14}$. Though it has not been ascertained whether the elevated oxidative state of tamoxifen resistant breast cancer is due to prolong tamoxifen exposure, the possibility that the prooxidant property of prolonged tamoxifen exposure may play a role in breast cancer resistance cannot be ignored.

Reactive oxygen species consist of a number of partially reduced metabolites of oxygen such as superoxide anions $\left(\mathrm{O}_{2}^{-}\right)$, hydrogen peroxide $\left(\mathrm{H}_{2} \mathrm{O}_{2}\right)$, and hydroxyl radicals $(\mathrm{OH} \cdot)$, characterized by higher reactivity than molecular oxygen. These reactive species are known to play a vital role in cell growth mediated by $17 \beta$ estradiol (E2) ${ }^{15}$. Oxidative 
stress has been shown to instigate a number of varied responses including cell proliferation and transformation. Furthermore, an excessive and/or sustained increase in ROS production has been implicated in the pathogenesis of cancer ${ }^{16}$. Redox balance is achieved by various enzymatic and non enzymatic antioxidant systems that counteract the harmful effect of ROS. For example, superoxide dismutase (SOD) catalyses the dismutation of the superoxide anion into $\mathrm{H}_{2} \mathrm{O}_{2}$, while Catalase and glutathione peroxidase (GPx) metabolize $\mathrm{H}_{2} \mathrm{O}_{2}$ into water and molecular oxygen ${ }^{17,}{ }^{18}$. It is interesting to note that physiological ROS play a significant role in the regulation of signaling pathways such as kinase and phosphatase activation/inactivation.

Oxidative stress-induced redox surges could bring about changes in the thiol status of signaling proteins with alterations in their Phosphorylation/dephosphorylations functions. These modifications could lead to changes in cellular signaling transduction pathways, DNA and RNA syntheses, protein syntheses, enzyme activation and cell cycle regulations ${ }^{19-27}$. Signaling proteins such as mitogen-activated protein kinases (MAPK) ${ }^{27}$ and protein tyrosine phosphatases (PTPs) like PTEN (Phosphatase and tensin homolog deleted on chromosome ten) and CDC25 ${ }^{28}$ have been shown to be susceptible to oxidation because they contain essential cysteines which serve as possible targets for ROS in different pathways ${ }^{30,31}$.

Protein tyrosine phosphatases (PTPs) are important enzymes in cell cycle control and signal transduction. In conjunction with protein tyrosine kinases (PTKs), PTPs regulate levels of protein tyrosine phosphorylation in response to cellular signals ${ }^{32,33}$. Many 
studies have shown that PTKs may be directly activated through the inhibition of PTPs by $\operatorname{ROS}^{34,35}$. For example, PTEN is a redox sensitive phosphatase which has been shown to be inactivated by ROS. The inactivation of PTEN leads to the sustained phosporylation and activation of AKT. AKT has been shown to phosphorylate p27 on threonine 157 with a resultant cytoplasmic sequestration and a consequent inhibition of its nuclear function.

p27 is a Cyclin-kinase inhibitor (CKI) which was originally discovered as a protein whose expression was induced by different growth inhibitory conditions/agents such as serum starvation, contact inhibition, transforming growth factor- $\alpha$ or by lovastatin ${ }^{36}$. Its expression is reduced by mitogens like epidermal growth factors and estrogens. Mice with p27 knockout develop multiorgan hyperplasia and pituitary tumors, thus underscoring a role for $\mathrm{p} 27$ in both proliferation and differentiation ${ }^{37}$. p27 is also wellknown for its ability to inhibit G1 Cyclin/CDK complexes. It is noteworthy that its activity is regulated by its post-translational modification ${ }^{38,39}$. Hence one may infer that because of their capacity to oxidize and inactivate PTEN, ROS may be able to regulate p27 function by modulating its post-translational modification.

We therefore hypothesized that (i) in addition to its known action at the ER, tamoxifen also prevents estrogen-mediated progression of cell cycle by counteracting estrogeninduced reactive oxygen species signaling, and (ii) as a result of chronic oxidative stress, and the conversion of estrogen-sensitive breast tumors to a tamoxifen-resistant phenotype is associated with a progressive shift towards a pro-oxidant environment. Therefore, an increase in ROS levels promotes the loss of p27 inhibitory function through the 
inactivation of protein tyrosine phosphates (PTPs) and a consequent change in p27 phosphorylation.

To test these hypotheses, we conducted experiments to i) determine the relationship between tamoxifen and oxidative stress, ii) determine the effect of ROS on p27 expression and its phoshorylation in tamoxifen resistant LCC2 cells, iii) determine if pretreatment of LCC2 cells with biological or chemical antioxidants can restore tamoxifen sensitivity by re-establishing redox balance within the cells, and iv) determine the effect of antioxidants on p27 stability and its inhibitory function.

\section{Materials and methods}

\section{Materials}

Antibodies to p27, Cyclin E, CDK2 and Phosphorylated p27 on Threonine187 were purchased from Santa Cruz Biotechnology. T157 Phosphorylated p27 antibody was purchased from Abcam. Beta Actin, 2', 7'-dichlorodihydrofluorescein diacetate (DCFHDA), DMSO, Ebselen and cyclohexamide were purchased from Sigma Aldrich. Exactacruz immune- precipitation kit was purchased from Santa Cruz Biotechnology. BrdU kit was purchased from ROCHE. Protein A Agarose was purchased from Invitrogen. The adenoviruses AdEmpty (EV), AdMnSOD (SOD), and AdCatalase (CAT) were purchased from ViraQuest, Inc. (North Liberty, IA, USA). 


\section{Cell culture}

LCC2 cells were provided by Dr Slingerland (Braman Family Breast Cancer Institute, Miami)). Cells were cultured in DMEM (Gibco) containing 5\% Fetal bovine serum (FBS), 25,000 units of penicillin (base) and 25,000 $\mu \mathrm{g}$ of Streptomycin at $37^{\circ} \mathrm{C}$ in a fully humidified atmosphere of $5 \% \mathrm{CO}_{2}$ in air. For experiments, $40 \%$ Confluent cells were further cultured in DMEM containing 5\% Charcoal Stripped FBS for 24hours to minimize the effect of serum and synchronize the cells in G1. Synchronized cells were always treated with $0.01 \%$ DMSO, 1uM Tamoxifen (TAM), 100pg E2 or 1uM fulvestrant.

\section{Adenoviral Transduction}

The adenoviruses AdEmpty (EV), AdMnSOD (SOD), and AdCatalase (CAT) were manufactured at ViraQuest, Inc. (North Liberty, IA, USA) by inserting either Ad5 E1/partial E3-deleted replication-deficient adenoviral vector only (EV) or the vector containing MnSOD (SOD) or Catalase (CAT) gene in the E1 region of the vector.

LCC2 cells were seeded in 100-mm dishes at a density of $1 \times 10^{6}$ cells/dish in the medium containing charcoal stripped FBS for $24 \mathrm{hrs}$. The medium was then aspirated and replaced with $5 \mathrm{ml}$ of serum-free medium containing $50 \mathrm{pfu}$ of SOD, CAT or EV adenovirus. After 2 hours of incubation, $10 \%$ of charcoal stripped serum was added to the medium making it 5\% charcoal stripped medium. Medium was changed after 24 hours of adenoviral exposure and treatment(s) were added to pre-designated plates and incubated for another 48 hours. 


\section{Ebselen Pre-treatment}

$1 \times 10^{6}$ LCC2 cells were seeded per $100 \mathrm{~mm}$ dish in medium with $5 \%$ Charcoal stripped serum. 21 hours post seeding $20 \mu \mathrm{M}$ of Ebselen was added to the culture and incubated for 3hours. Desired treatments were then added to the culture and incubated for 48 hours.

\section{BrdU Incorporation Assay}

For BrdU incorporation, LCC2 cells were seeded in 96-well plates at a density of $2500 /$ well and incubated in $5 \% \mathrm{CO} 2$ incubator at $37^{\circ} \mathrm{C} .24$ hours after seeding, cells were either infected with EV, CAT or SOD at a multiplicity of infection (m.o.i) of 50pfu/cell as described above or pre-treated with $20 \mu \mathrm{M}$ of Ebselen. After exposure to antioxidants cells were then stimulated with either 0.01\% DMSO, E2 (100pg), TAM (1uM) or E2 + TAM for 48hours. Following the above treatment, BrdU incorporation assay was carried out using Cell Proliferation ELISA, BrdU labeling Kit (Roche Molecular Biochemical) in accordance with manufacturer's recommendation. Colorimetric changes were acquired at $370 \mathrm{~nm}$ with a Tecan Genios microplate reader.

\section{2', 7'-dichlorofluorescin diacetate (DCFH-DA)}

To carry out the DCFH-DA Assay, 10,000/well of LCC2 cells were seeded in a 96-well plate and cultured in $10 \%$ growth medium for 24 hours. After 24 hours growth medium was aspirated and replaced with serum free medium for another 24 hours after which the starvation media was aspirated and replaced with $100 \mathrm{uL} /$ well of HBSS containing $10 \mu \mathrm{M}$

DCFDA pre-diluted with Pluronic F-127 and incubated at $37^{\circ} \mathrm{C}$ for 20 mins. At the end of the incubation, DCFH-DA solution was gently aspirated and pre-designated wells were 
then stimulated with 100ul of HBSS containing either 0.01\% DMSO (vehicle control), E2 (100pg), TAM (1uM) or E2 + TAM. Cells were further incubated for 5mins after which fluorescence readings were taken using $485 \mathrm{~nm}$ and $535 \mathrm{~nm}$ as excitation and emission filters, at intervals of 5 mins. Optical density readings were obtained using a Tecan Genios microplate reader.

\section{Western blot}

$1 \times 10^{6}$ LCC2 cells per $100 \mathrm{~mm}$ dish were initially exposed to antioxidants as described above and then stimulated with either $0.01 \% \mathrm{DMSO}, 1 \mu \mathrm{M}$ TAM, or $1 \mu \mathrm{M}$ fulvestrant for 48hours. Post treatment, cells were harvested and lysed in radioimmunoprecipitation assay (RIPA) buffer $[25 \mathrm{mM}$ Tris $\mathrm{HCl}$ (pH 7.4), $25 \mathrm{mM} \mathrm{NaCl}, 1 \mathrm{mM}$ sodium orthovanadate, $10 \mathrm{mM}$ sodium pyrophosphate, $10 \mathrm{mM} \mathrm{NaF}, 0.5 \mathrm{mM}$ EGTA, $1.0 \%$ Triton X-100, $1 \mathrm{mM}$ PMSF, and $10 \mathrm{mM}$ okadaic acid] for $15 \mathrm{~min}$ on ice. Samples were then briefly sonicated and centrifuged at $10,000 \mathrm{rpm}$ for $10 \mathrm{~min}$ at $4{ }^{\circ} \mathrm{C}$. The total protein concentration of the resulting supernatant was determined by Pierce BCA quantification kit. Equal amount of protein extracts $(50 \mu \mathrm{g})$ were separated by SDS-PAGE, transferred to a polyvinylidene difluoride membrane (PVDF), blocked in $1 \% \mathrm{BSA}$ and fat free milk solution containing $50 \mathrm{mM}$ NAF for 1 hour and blotted with antibodies. Labeled proteins are visualized with an ECL system (Amersham Biosciences). Band intensity was determined using densitometric analysis (NIH ImageJ software). The level of p27 was expressed as its ratio to $\beta$-actin. 
For chronic exposure, after exposing cells to antioxidants cells were stimulated with either DMSO, TAM, or fulvestrant for 21 days after which the cells were harvested for lysate preparation and Immunoblotting as described above.

\section{Co-immunoprecipitation}

For co-immunopreipitation to determine Cyclin E complexes, the Exactacruz protocol was followed according to the manufacturer's recommendation. Briefly, after stimulation, lysate was prepared using ice-cold Nonidet P-40 lysis buffer $(0.1 \%$ Nonidet P-40, $50 \mathrm{mM}$ Tris [pH 7.5], $150 \mathrm{mM} \mathrm{NaCl}, 1 \mathrm{mM}$ phenylmethylsulfonyl fluoride, and $0.02 \mathrm{mg}$ each of aprotinin, leupeptin, and pepstatin per $\mathrm{ml}$ ). The lysate was then sonicated briefly and centrifuged at 10,000 rpm for 10 mins. Supernatant was saved and then pre-cleared using $30 \mu 1$ of Exactacruz pre-clearing matrix for 30 minutes at $4^{\circ} \mathrm{C}$ while rotating. Matrix was pelleted by microcentrifugation at maximum speed for 30 seconds at $4^{\circ} \mathrm{C}$ and the supernatant (cell lysate) was transferred to a new micro centrifuge tube and BCA assay performed.

IP antibody-IP matrix complex was formed by adding $2 \mu \mathrm{g}$ of Cyclin E antibody to be immunoprecipitated to $40 \mu \mathrm{l}$ of suspended IP matrix and $500 \mu 1 \mathrm{PBS}$ and incubating at $4^{\circ}$ $\mathrm{C}$ on a rotator overnight. After overnight incubation, matrix was pelleted, supernatant discarded and pelleted matrix was washed two times with $500 \mu 1$ of PBS, each time while repeating the above centrifugation and aspiration steps. After the second wash and microcentrifugation, $300 \mu \mathrm{g}$ of pre-cleared lysate was added to the IP antibody-IP matrix complex, and incubated overnight at $4^{\circ} \mathrm{C}$ after which samples were microcentrifuged at 
maximum speed for 30 seconds at $4^{\circ} \mathrm{C}$ to pellet IP matrix and the pelleted matrix washed 2-4 times with NP40 lysis buffer and pelleted. After the final wash, $40 \mu 1$ of $2 \mathrm{X}$ reducing electrophoresis buffer was added to the pellet, boiled for 3 mins, quick-spinned and equal volumes loaded onto gel, resolved, transferred, and blotted with Cyclin E, Cdk2, and p27 antibodies. Antibody alone, and whole cell lysate controls were run alongside immunoprecipitates. The same was done for CDK2 and p27. Western blot anti-body was probed using the appropriate HRP conjugated ExactaCruz reagent.

\section{Soft Agar Colony Formation Assay.}

To assess the effect of antioxidants on anchorage-independent cell growth, a soft agar colony formation assay using either plain or antioxidant pretreated (Ebselen, Catalase or MnSOD) LCC2 cells was performed. LCC2 cells (1000/well) were suspended in $0.2 \mathrm{ml}$ of charcoal stripped culture medium containing $0.25 \%$ agar and appropriate treatment $(0.01 \%$ DMSO or $1 \mu \mathrm{M}$ Tamoxifen or fulvestrant) and poured over a pre-hardened feeder layer of agarose comprising $0.2 \mathrm{ml}$ of the charcoal stripped medium, containing $0.5 \%$ agar, in a 48 well plate. Cells were fed every 4 days and allowed to incubate for 30 days. After 14 days of incubation at $37^{\circ} \mathrm{C}$ in a humidified $\mathrm{CO} 2$ incubator, colonies were counted excluding any colonies with a diameter $\leq 60 \mu$ meter.

\section{P27 protein stability}

To determine the effect of antioxidants on p27 stability, $1 \times 10^{6}$ LCC 2 cells were seeded in $100 \mathrm{~mm}$ plates in medium with charcoal stripped FBS for 24 hours and then some cells were exposed to either Ebselen or 50 pfu of CAT, SOD or EV. After 24 hours media was 
replaced with fresh medium with charcoal stripped FBS alone for 40 hours. After which $50 \mu \mathrm{M}$ of cycloheximide was added to media for the indicated period spanning the next 8 hours. Cells were lysed in RIPA buffer for $60 \mathrm{~min}$ at $4^{\circ} \mathrm{C}$. Samples were then centrifuged at $10,000 \mathrm{~g}$ for $10 \mathrm{~min}$ at $4^{\circ} \mathrm{C}$. The total protein concentration of the resulting supernatant was determined by BCA quantification. Equal amount of protein extracts $(50 \mu \mathrm{g})$ were separated by SDS-PAGE, transferred to a PVDF membrane, blocked in 1\% BSA and fat free milk solution containing $50 \mathrm{mM}$ NAF for 1 hour and blotted with antibodies. Labeled proteins are visualized with an ECL system (Amersham Biosciences). Band intensity was determined using densitometric analysis (NIH ImageJ software). The level of $\mathrm{p} 27 \mathrm{kip}$ was expressed as its ratio to $\beta$-actin.

\section{Results}

\section{Antioxidants mitigate ROS formation in TAM resistant LCC2 cells}

To determine the effect of antioxidants on TAM-induced ROS in LCC2 cells, a DCFHDA assay was performed using cells with or without antioxidants. Data reveals that LCC2 cells generate ROS when exposed to TAM and E2 respectively and the ROS generated was significantly inhibited by the co-treatment of TAM with E2 (Figs. 1A). This observation implies that while individual treatment of LCC2 cells with E2 and TAM are pro-oxidant, TAM possesses an anti-oxidant effect in the presence of E2. Cotreatments of cells with either TAM or E2 and ROS modulators (biological or chemical) also inhibited TAM-induced ROS (Figs. 1B, C). 


\section{Antioxidants inhibits BrdU incorporation in TAM resistant cells}

A BrdU incorporation assay was carried out to determine the effect of antioxidants on ROS induced DNA synthesis in LCC2 cells. Experimental outcomes show that E2 and TAM-induced cell proliferation in LCC2 cells is significantly inhibited by the cotreatment of TAM with E2 (Fig. 2A) and by co-treatment of TAM or E2 with Biological (CAT or SOD) or chemical (Ebselen) ROS modulators (Figs. 2B, C). The ability of ROS

modulators to inhibit TAM or E2 induced DNA synthesis points to the pro-oxidant effect of TAM or E2 on LCC2 cells and the inherent capacity of this pro-oxidant environment to promote cell proliferation.

\section{Antioxidants mitigate anchorage independent growth in TAM resistant LCC2 cells.}

To determine the effect of antioxidants on anchorage-independent growth in TAM resistant cells, a colony assay was performed using LCC2 cells. Anchorage independent growth was significantly inhibited by fulvestrant but not by TAM or DMSO (Fig.3A). fulvestrant was included in this experiment as a positive control because LCC2 cells are sensitive to it. Ebselen pretreatment or the over expression of CAT or SOD in TAM resistant LCC2 cells significantly inhibited anchorage independent growth compared to EV infected or uninfected cells (Figs. 3B, C). This result further substantiates the prooxidant, growth inducing effect of TAM.

\section{Antioxidants increased p27 expression in TAM resistant cells}

Western blotting was carried out to determine the effect of antioxidants on TAM resistant cells. Fig. 4A reveals that the treatment of LCC2 cells with fulvestrant significantly 
increased p27 expression compared to TAM. Ebselen pretreatment or the over expression of CAT or SOD in LCC2 cells also resulted in a significant increase in p27 expression when treated with TAM compared to EV infected cells and uninfected cells (Fig.4B, C). This is similar to the effect observed following exposure to fulvestrant in Fig.4A. It may thus be inferred that the TAM induced pro-oxidant environment may promote LCC2 cell proliferation by decreasing $\mathrm{p} 27$ expression.

\section{Antioxidants decreased p27 phosphorylation in TAM resistant cells}

Western blotting was also carried out to determine the effect of antioxidants on p27

phosphorylation. Panel I. Results obtained from this experiment show that treatment of uninfected LCC2 cells with fulvestrant resulted in significantly reduced phosphorylation of p27 on Threonine 157(T157) relative to TAM treated cells which showed a phosphorylation level that was $\geq \mathrm{T} 157$ phosphorylation in cells exposed to DMSO control (Fig.5A). Over expression of CAT or SOD or Ebselen pretreatment in LCC2 cells leads to a significant decrease in T157 phosphorylation when treated with TAM compared to either EV infected control or uninfected cells. (Figs.5B, C). Once again the cells exposed to ROS modulators acted like those exposed to fulvestrant by showing a decrease in p27 phosphorylation on T157 unlike the unexposed cells which showed an increase in T157 phosphorylation. It is noteworthy that phosphorylation of p27 on T157 results in increased cytoplasmic sequestration of $\mathrm{p} 27$ and vice versa.

Panel II. In Fig.5A Experimental outcome reveals a significant reduction of p27 phosphorylation on Threonine 187 (T187) in LCC2 cells exposed to fulvestrant compared 
to TAM. (B) LCC2 cells over expressing CAT or SOD or pretreated with Ebselen also shows a significant reduction in the level of p27 phosphorylation on T187 when treated with TAM compared to either EV control or uninfected cells.

A result similar to the one obtained for T157.

\section{Prolonged exposure of LCC2 cells to antioxidants and TAM treatment increased p27 expression}

Immunoblotting was carried out to determine the effect of chronic antioxidant and TAM exposure on p27 expression. Results obtained show that prolonged (21 days) exposure of LCC2 cells to fulvestrant significantly increased p27 expression compared to TAM (Fig. 6A). Over expression of CAT or SOD in LCC2 cells also resulted in a significant increase in p27 expression when treated with TAM compared to EV infected cells and uninfected cells (Fig.6B). This shows that chronic exposure to antioxidants and TAM have the same outcome as short term (48hrs) exposure.

\section{Prolonged exposure of $\mathrm{LCC} 2$ cells to antioxidants and TAM treatment reduced p27} phosphorylation

The following are results from Immunoblotting to determine the effect of antioxidants on p27 phosphorylation. Panel I. Chronic treatment of uninfected LCC2 cells with fulvestrant resulted in a significant reduction in the phosphorylation of p27 on Threonine 157(T157) compared to TAM treated cells which showed an increase in the level of p27

phosphorylation on T157(Fig.7A). Treatment of LCC2 cells over expressing CAT or 
SOD also resulted in a reduction in phosphorylation when compared to either EV control or uninfected cells exposed TAM (Fig.7B).

Panel II. Fig.8A shows that chronic exposure of LCC2 cells to fulvestrant resulted in a significant reduction in the level of p27 phosphorylation on Threonine 187 (T187) compared to TAM. LCC2 cells over expressing CAT or SOD upon treatment with TAM showed a significant reduction in phosphorylation when compared to either EV control or uninfected cells exposed to TAM.

\section{Antioxidants increased p27 binding to CylinE and CDK2 in TAM resistant cells}

To determine the effect of Antioxidants on p27 binding to CDK2 and or CyclinE a coimmunoprecipitation was performed. Treatment of LCC2 cells with fulvestrant resulted in an increase in p27 binding to CDK2 and CyclinE compared to TAM treatment (Fig. 8A). Ebselen pretreatment or the Over expression of CAT or SOD in LCC2 also resulted in increased binding of p27 to CDK2 and CyclinE when treated with TAM compared to either EV infected controls or uninfected cells exposed to TAM (Fig.8B, C).

\section{Antioxidants increased CDK2 binding to P27 and CyclinE in TAM resistant cells To} determine the effect of Antioxidants on p27 binding to CDK2 and or CyclinE a coimmunoprecipitation was performed. Treatment of LCC2 cells with fulvestrant resulted in an increase in CDK2 binding to p27 and CyclinE compared to TAM treatment (Fig. 9A). Ebselen pretreatment or the Over expression of CAT or SOD in LCC2 also resulted 
in increased binding of CDK2 to p27 and CyclinE when treated with TAM compared to either EV infected controls or uninfected cells exposed to TAM (Fig.9B, C).

\section{Antioxidant Increased CylinE binding to CDK2 and p27 in TAM resistant cells}

To determine the effect of antioxidants on CyclinE binding to CDK2 and or p27 a coimmunoprecipitation was performed. In (Fig. 10A), treatment of LCC2 cells with fulvestrant resulted in an increase in CyclinE binding to CDK2 and p27 compared to TAM while data from (Fig.10B, C) also showed increased CyclinE binding to CDK2 and p27 in LCC2 cells over expressing CAT or SOD compared to either EV infected cells or uninfected cells exposed to TAM.

\section{P27 expression is less in LCC2 cells compared to MCF7 when synchronized}

Pursuant to the finding in Figures 4 and 5 Immunoblotting was performed to compare the levels of p27 in TAM resistant LCC2 cells to its parent MCF7 cells. Results obtained showed the level of p27 expression in LCC2 to be about $40 \%$ less than that in MCF7 cells of equal protein concentration, exposed to the same experimental conditions.

\section{Antioxidants Increased p27 stability in TAM resistant cells}

To determine p27 stability a stability assay was performed using cycloheximide. LCC2 cells not pre-exposed to antioxidants had a shorter half life (2.42hours) compared to CAT or SOD over expressing cells. 


\section{Discussion}

In this study, we hypothesized that, (i) In addition to its known action at the ER, TAM also prevents estrogen-mediated progression of cell cycle by counteracting estrogeninduced ROS signaling, and (ii) As a result of chronic oxidative stress, the conversion of estrogen-sensitive breast tumors to a Tamoxifen-resistant phenotype is associated with a progressive shift towards a pro-oxidant environment. We therefore propose that an increase in ROS levels promotes the loss of p27 inhibitory function through the inactivation of protein tyrosine phosphates (PTPs) and a consequent change in p27 phosphorylation.

TAM, a known selective estrogen receptor modulator (SERM), has been widely shown to possess either pro- or antioxidant properties ${ }^{7-13}$. Our results show that TAM possesses the capacity to act like both an oxidant and an antioxidant. Exposure of LCC2 cells to TAM or E2 induced the formation of reactive oxidants (Fig.1A). These reactive oxidants were then inhibited by the co-treatment of E2 with TAM, much like the ROS inhibition observed in cells pre-treated with antioxidants (Figs.1B \& C). We further demonstrated that E2 and TAM induced ROS in LCC2 cells were capable of inducing cell proliferation which was then inhibited by pre-exposure of the cells to biological or chemical antioxidants or the co-treatment of TAM with E2 (see Figs.2 \& 3). These findings make a case for the dual role of TAM as both a pro- and an antioxidant. Based on these results, it appears that the antioxidant effect of TAM is observed in the presence of E2.

Exposure of TAM resistant LCC2 cells to TAM resulted in a decrease in p27 expression in contrast to the increase in p27 expression observed when the same cells were treated 
with fulvestrant (see Fig.4A). Fulvestrant is an anti-estrogen to which LCC2 cells are known to be sensitive. We also observed that the exposure of these cells to TAM increased p27 phosphorylation on T157 and T187 while exposure to fulvestrant appeared to have the opposite effect (Fig5. Panels 1\& IIA).

Conversely, following the antioxidant pre-treatment/over expression, a fulvestrant-like effect i.e., an increase in p27 expression (see Figs. 4B \&C) and a decrease in p27 phosphorylation on T157 and T187 was observed in TAM treated cells compared to cells which were not pre-exposed to antioxidants (Figs. 5 Panels I \& II B \& C). It can thus be inferred that the over expression of antioxidant in LCC2 cells leads to an increase in p27 expression and a decrease in its phosphorylation on T157 and T187. This is in line with other previous studies ${ }^{40-42}$, which showed that treatment with anti-estrogen drugs like TAM or fulvestrant caused cell cycle arrest, with up-regulation of p21 and p27 levels, an increase in their binding to Cyclin E-Cdk2, and kinase inhibition ${ }^{40}$. Additionally, results from our comparison of $\mathrm{p} 27$ expression between Tamoxifen sensitive parental MCF7 and Tamoxifen resistant LCC2 cells showed a 40\% decrease in p27 expression in LCC2 cells compared to MCF7 (Fig.11). This implies that TAM resistance could be associated with a decrease in p27 expression rather than the loss p27 function in which case, an increase in p27 expression following antioxidant pre-treatment is a significant finding.

Though the observed experimental outcomes imitate the effect of fulvestrant on LCC2 cells, we cannot yet interpret this to either denote an increase in TAM sensitivity or the growth inhibitory function of $\mathrm{p} 27$. This is because previous studies have indicated that 
p27 potentially has dual role(s) in tumor - suppression and promotion ${ }^{43-46}$ depending on its subcellular redistribution and its binding to the Cyclin-Cdk complex. The binding of p27 to the Cyclin E/Cdk2 complex in the nucleus promotes its function as a CKI while cytoplasmic sequestration takes it away from its nuclear Cyclin/Cdk target to the growth promoting interaction with Cyclin D/Cdk4/6 complex ${ }^{47}$.

In line with previous studies ${ }^{40}$, we also found an increase in the binding of Cyclin ECdk2 and p27 in TAM treated cells over expressing antioxidant (CAT and SOD) compared to control cells not exposed to antioxidants (see Figs. $8,9 \& 10$ ). In the context of our initial finding of increased p27 expression and decreased phosphorylation, these results of increased binding of p27 to Cyclin E-Cdk2 and increased p27 stability in cells over expressing antioxidants (Fig. 12), are highly suggestive of an increase in the TAM sensitivity, most likely due to $\mathrm{p} 27$ inhibitory function in antioxidant over expressing LCC2 cells.

In summary, we demonstrate that TAM has the capacity to induce ROS formation and act as an antioxidant in the presence of E2. Following prolonged exposure to TAM and an increasingly pro-oxidant environment, the oxidants formed are able to promote cell proliferation. This could be by decreasing p 27 expression and regulation of its activity by post-translational modification involving an increase in p27 phosphorylation on T157 and T187. This is accompanied by a resultant cytoplasmic sequestration, decreased binding to Cyclin E/Cdk2 complex and loss of p27 stability resulting in the loss of sensitivity to TAM. Clearly, these events are oxidant driven, therefore they can be reversed by 
antioxidant over expression or pre-treatment, with a resultant growth inhibitory effect and increased TAM sensitivity.

\section{List of References}

(1) Rebecca B. Riggins1, Randy S. Schrecengost, Michael S. Guerrero2, and Amy H. Bouton. Pathway to Tamoxifen resistance. Cancer Lett 2007 October 18; 256(1): 124.

(2) Lewis JS, Jordan VC. Selective estrogen receptor modulators (SERMs): Mechanisms of anti-carcinogenesis and drug resistance. Mutat Res 2005; 591:247263.

(3) Riggins RB, Bouton AH, Liu MC, Clarke R. Anti-estrogens, aromatase inhibitors, and apoptosis in breast cancer. Vitam Horm 2005; 71:201-237.

(4) Toyokuni S, Okamoto K, Yodoi J, Hiai H. Persistent oxidative stress in cancer. FEBS Lett 1995; 358:1-3.

(5) Sies H. Oxidative stress: oxidants and antioxidants. Exp Physiol 1997; 82:291-295.

(6) Besson, A., Dowdy, S. F. and Roberts, J. M. CDK inhibitors: Cell cycle regulators and Beyond. Dev. Cell 2008; 14, 159-69.

(7) Wiseman H. Tamoxifen as an antioxidant and cardioprotectant. Biochem Soc Symp $1995 ; 61: 209-219$.

(8) Wiseman H, Paganga G, Rice-Evans C. Protective actions of tamoxifen and 4Hydroxyl-tamoxifen against oxidative damage to human low-density lipoproteins: a Mechanism accounting for the cardioprotective action of tamoxifen? Biochem J 1993; 292:365-368.

(9) Wiseman H, Laughton MJ, Arnstein HRV, Cannon M, Halliwell B: The antioxidant action of tamoxifen. Inhibition of lipid peroxidation. FEBS Lett 1990; 263: 192-194.

(10) Wiseman H, Paganga G, Rice-Evans C, Halliwell B: Protective actions of tamoxifen and 4-hydroxytamoxifen against oxidative damage to human low-density lipoproteins: A mechanism accounting for the cardioprotective action of tamoxifen? Biochem J 1993; 292: 635-638.

(11) Brown NS, Bicknell R. Hypoxia and oxidative stress in breast cancer. Oxidative stress: its effects on the growth, metastatic potential and response to therapy of breast cancer. Breast Cancer Res 2001 3:323-327. 
(12) El-Beshbishy HA. The effect of dimethyl dimethoxy biphenyl dicarboxylate (DDB) against tamoxifen-induced liver injury in rats: DDB use is curative or protective. $J$ Biochem Mol Biol 2005; 38:300-306

(13) Da Costa GG, McDaniel-Hamilton LP, HeXich RH, Marques MM, Bel and FA; DNA adduct formation and mutant induction in Sprague-Dawley rats treated with tamoxifen and its derivatives. Carcinogenesis 2001; 22:1307-1315

(14) Tabassum H, Rehman H, Banerjee BD, Raisuddin S, Parvez S. Attenuation of tamoxifen-induced hepatotoxicity by taurine in mice. Clin Chim Acta 2001; 370:129-136

(15) Roy D, Cai Q, Felty Q, Narayan S. Estrogen-induced generation of reactive oxygen and nitrogen species, gene damage, and estrogen-dependent cancers. J Toxicol Environ Health B Crit Rev 2007 June; 10(4):235-57.

(16) Droge W. Free radicals in the physiological control of cell function. Physiol Rev 2002 January; 82 (1):47-95.

(17) Polat MF, Taysi S, Gul M, Cikman O, Yilmaz I, Bakan E, Erdogan F. Oxidant/antioxidant status in blood of patients with malignant breast tumor and benign breast disease. Cell Biochem Funct 2002; 20:327-331.

(18) Bakan N, Taysi S, Yilmaz O, Bakan E, Kuskay S, Uzun N, Gundogdu M. Glutathione peroxidase, glutathione reductase, $\mathrm{Cu}-\mathrm{Zn}$ superoxide dismutase activities, glutathione, nitric oxide and malondialdehyde concentrations in serum of patients with chronic lymphocytic leukemia. Clin Chim Acta 2003 338:143-149.

(19) Abate C, Patel L, Rauscher FJ, III, Curran T. Redox regulation of fos and jun DNAbinding activity in vitro. Science 1990 September 7; 249(4973):1157-61.

(20) Matthews JR, Wakasugi N, Virelizier JL, Yodoi J, Hay RT. Thioredoxin regulates the DNA binding activity of NF-kappa $\mathrm{B}$ by reduction of a disulphide bond involving cysteine 62. Nucleic Acids Res 1992 August 11; 20 (15):3821-30.

(21) Arrigo AP. Gene expression and the thiol redox state. Free Radic Biol Med 1999 November; 27(9-10):936-44.

(22) Suzuki YJ, Forman HJ, Sevanian A. Oxidants as stimulators of signal transduction. Free Radic Biol Med 1997; 22(1-2):269-85.

(23) Powis G, Gasdaska JR, Baker A. Redox signaling and the control of cell growth and death Adv Pharmacol 1997; 38:329-59.

(24) Sen CK, Packer L. Antioxidant and redox regulation of gene transcription. FASEB J 
1996 May; 10(7):709-20.

(25) Shackelford RE, Kaufmann WK, Paules RS. Oxidative stress and cell cycle Checkpoint function. Free Radic Biol Med 2000 May 1; 28(9):1387-404.

(26) Nakamura H, Nakamura K, Yodoi J. Redox regulation of cellular activation. Annu Rev Immunol 1997; 15:351-69.

(27) Haufel T, Dormann S, Hanusch J, Schwieger A, Bauer G. Three distinct roles for TGF-beta during intercellular induction of apoptosis: a review. Anticancer Res 1999 January;19(1A):105-11.

(28) Rudolph J. Redox regulation of the Cdc25 phosphatases. Antioxid Redox Signal 2005 May;7(5-6):761-7.

(29) Denu JM, Tanner KG. Specific and reversible inactivation of protein tyrosine Phosphatases by hydrogen peroxide: evidence for a sulfenic acid intermediate and implications for redox regulation. Biochemistry 1998 April 21; 37(16):5633-42.

(30) Holmgren A. Thioredoxin structure and mechanism: conformational changes on oxidation of the active-site sulfhydryls to a disulfide. Structure 1995 March $15 ; 3(3): 239-43$.

(31) Hecht D, Zick Y. Selective inhibition of protein tyrosine phosphatase activities by $\mathrm{H}_{2} \mathrm{O}_{2}$ and vanadate in vitro. Biochem Biophys Res Commun 1992 October 30; 188 (2):773-9.

(32) Heffetz D, Rutter WJ, Zick Y. The insulinomimetic agents $\mathrm{H} 2 \mathrm{O} 2$ and vanadate stimulate tyrosine phosphorylation of potential target proteins for the insulin receptor kinase in intact cells. Biochem J 1992 December 1; 288 (Pt 2):631-5.

(33) Lee SR, Kwon KS, Kim SR, Rhee SG. Reversible inactivation of protein-tyrosine phosphatase 1B in A431 cells stimulated with epidermal growth factor. J Biol Chem 1998 June 19; 273(25):15366-72.

(34) Shifrin VI, Davis RJ, Neel BG. Phosphorylation of protein-tyrosine phosphatase PTP-1B on identical sites suggests activation of a common signaling pathway during mitosis and stress response in mammalian cells. J Biol Chem 1997 January 31; 272(5):2957-62.

(35) Sherr CJ, Roberts JM: CDK inhibitors: positive and negative regulators of G1-phase progression. Genes Dev 1999; 13:1501-1512.

(36) Borriello, A., Cucciolla, V., Oliva, A., Zappia, V. and Della Ragione, F. p27Kip1 metabolism: A fascinating labyrinth. Cell Cycle 2007; 6, 1053-61. 
(37) Chu, I., Hengst, L. and Slingerland, J. The Cdk inhibitor p27 in human cancer: Prognostic potential and relevance to anticancer therapy. Nat. Rev. Cancer 2008; 8, 253-267.

(38) Kaldis, P. Another piece of the p27Kip1 puzzle. Cell 2007;128, 241-4.

(39) Sicinski, P., Zacharek, S. and Kim, C. Duality of p27Kip1 function in tumorigenesis. Dev 2007; 21, 1703-6.

(40) Cariou S, Donovan JC, Flanagan WM, Milic A, Bhattacharya N, Slingerland JM. Down-regulation of $\mathrm{p} 21 \mathrm{WAF} 1 / \mathrm{CIP} 1$ or p27Kip1 abrogates antiestrogen-mediated cell cycle arrest in human breast cancer cells. Proc Natl Acad Sci SA2000;97:9042 -9046 .

(41) Carroll JS, Lynch DK, Swarbrick A, Renoir JM, Sarcevic B, Daly RJ, et al. p27(Kip1) induces quiescence and growth factor insensitivity in tamoxifen-treated breast cancer cells. Cancer Res 2003; 63:4322-4326.

(42) Slingerland J, Pagano M. Regulation of the cdk inhibitor p27 and its deregulation in cancer. J Cell Physiol 2000; 183:10-17.

(43) Chu, I., Hengst, L. and Slingerland, J. The Cdk inhibitor p27 in human cancer: Prognostic potential and relevance to anticancer therapy. Nat. Rev. Cancer 2008; 8 , 253-267.

(44) Kaldis, P. Another piece of the p27Kip1 puzzle. Cell 2007; 128, 241-4.

(45) Sicinski, P., Zacharek, S. and Kim, C. Duality of p27Kip1 function in tumorigenesis. Genes Dev 2007; 21, 1703-6.

(46) Besson, A., Hwang, H.C., Cicero, S., Donovan, S.L., Gurian-West, M., Johnson, D., Clurman, B.E., Dyer, M.A., and Roberts, J.M. 2007. Discovery of an oncogenic activity in $\mathrm{p} 27 \mathrm{Kip} 1$ that causes stem cell expansion and a multiple tumor phenotype. Genes \& Dev.(this issue), doi: 10.1101/gad.1556607.

(47) Vervoorts. J and Luscher B. Post-translational regulation of the tumor suppressor p27KIP1:a review. Cell. Mol. Life Sci. 2008; 653255 - 3264 


\section{Figures and Legend}

Fig 1-LCC2.

(A)

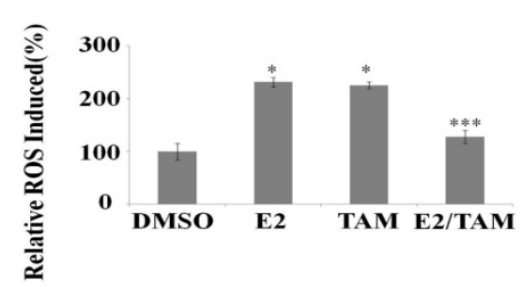

(C)

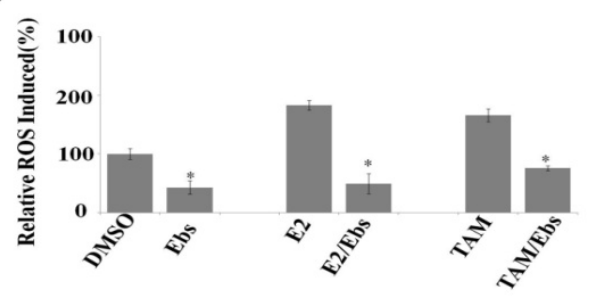

(B)

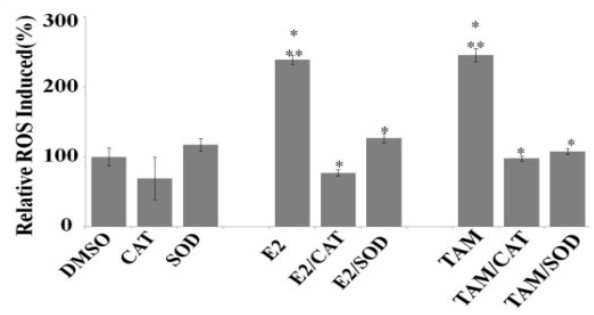

Antioxidants mitigate ROS formation in TAM resistant LCC2 cells. To determine the effect of antioxidants on TAM induced ROS in LCC2 cells, 1 x $10^{4}$ cells/well were seeded in a 96-well plate overnight and serum starved for $24 \mathrm{hrs}$. Post-starvation $100 \mu \mathrm{L} /$ well of HBSS containing $10 \mu \mathrm{M}$ DCFH-DA pre-diluted with Pluronic F-127 was added to each well and incubated at $37^{\circ} \mathrm{C}$ for 20 mins. DCFH-DA solution was then aspirated and replaced with $100 \mu \mathrm{L}$ of HBSS containing the desired treatments. Cells were further incubated for 5 mins and fluorescence readings were taken using $485 \mathrm{~nm}$ and $535 \mathrm{~nm}$ as excitation and emission filters, at intervals of 5mins. A) LCC2 cells treated with TAM, E2 or TAM/E2; B) TAM resistant cells over expressing Catalase (CAT) and MnSOD (SOD) were treated with TAM, E2 or TAM/E2; C) LCC2 cells co-treated with Ebselen and TAM, E2 or TAM/E2. Assay was performed 3x and data is expressed as mean percentage change from control $+/-\mathrm{SE},(p 0.05) .\left(^{*}\right)$ denotes significance when treatment is compared to DMSO control, $(* *)$ indicates significance when compared to EV/DMSO 
control while $(* * *)$ indicates significance when treatment is compared to DMSO and each individual treatment.

\section{Fig 2-LCC2}
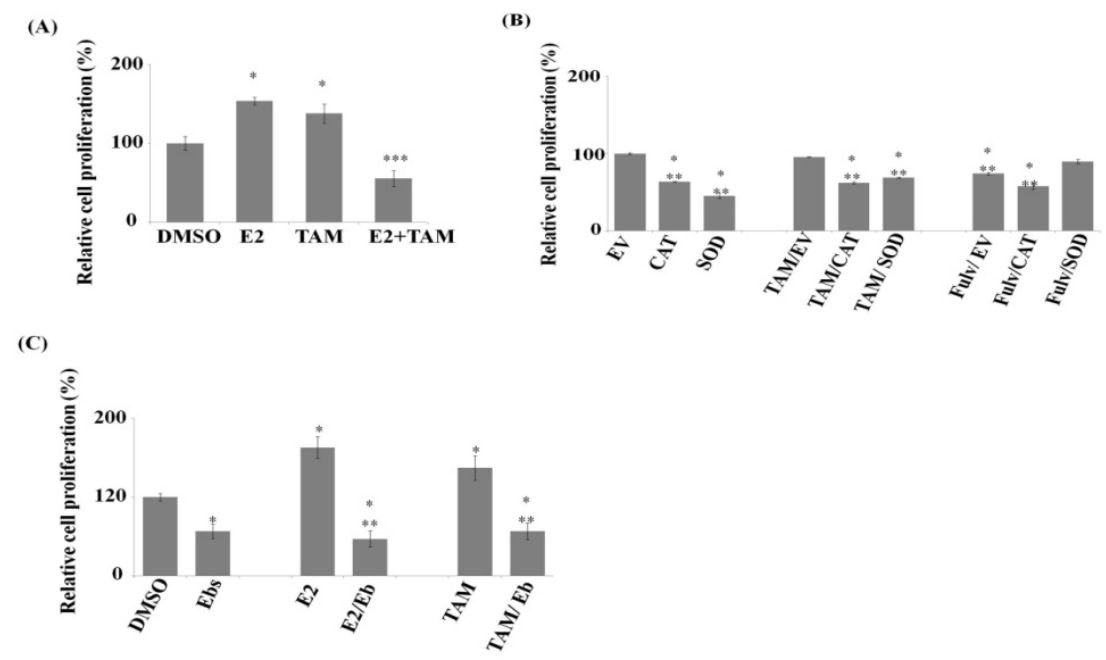

Antioxidants inhibit BrdU incorporation in TAM resistant cells. To determine the effect of antioxidants on ROS induced DNA synthesis in LCC2 cells, $2.5 \times 10^{3}$ cells/well were seeded in a 96-well plate overnight and exposed to chemical or biological antioxidants as described in methods. After exposure to antioxidants, cells were then stimulated with E2, TAM or fulvestrant for $46 \mathrm{hrs}$ and pulsed labeled with BrdU for 2 hrs. BrdU assay was then carried out as recommended by manufacturer. Colorimetric changes were acquired at $370 \mathrm{~nm}$ with a Tecan Genios microplate reader at 5 mins interval. A) LCC2 cells treated with TAM, E2 or TAM/E2; B) TAM resistant cells over expressing CAT and SOD and treated with TAM, E2 or TAM/E2; C) LCC2 cells cotreated with Ebselen and TAM, E2 or TAM/E2. Assay was performed 3x and data is expressed as mean percentage change from control +/- SE, ( $p$ 0.05). (*) denotes significance when treatment is compared to DMSO control, $(* *)$ indicates significance 
when compared to EV/DMSO control while $(* * *)$ indicates significance when treatment is compared to DMSO and each individual treatment.

Fig 3-LCC2

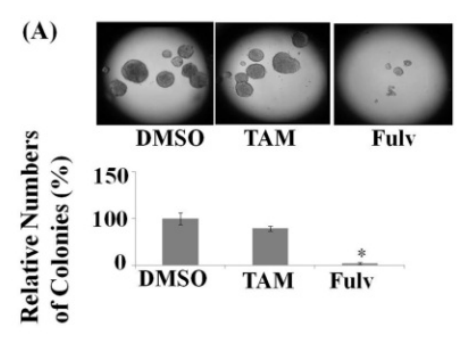

(C)
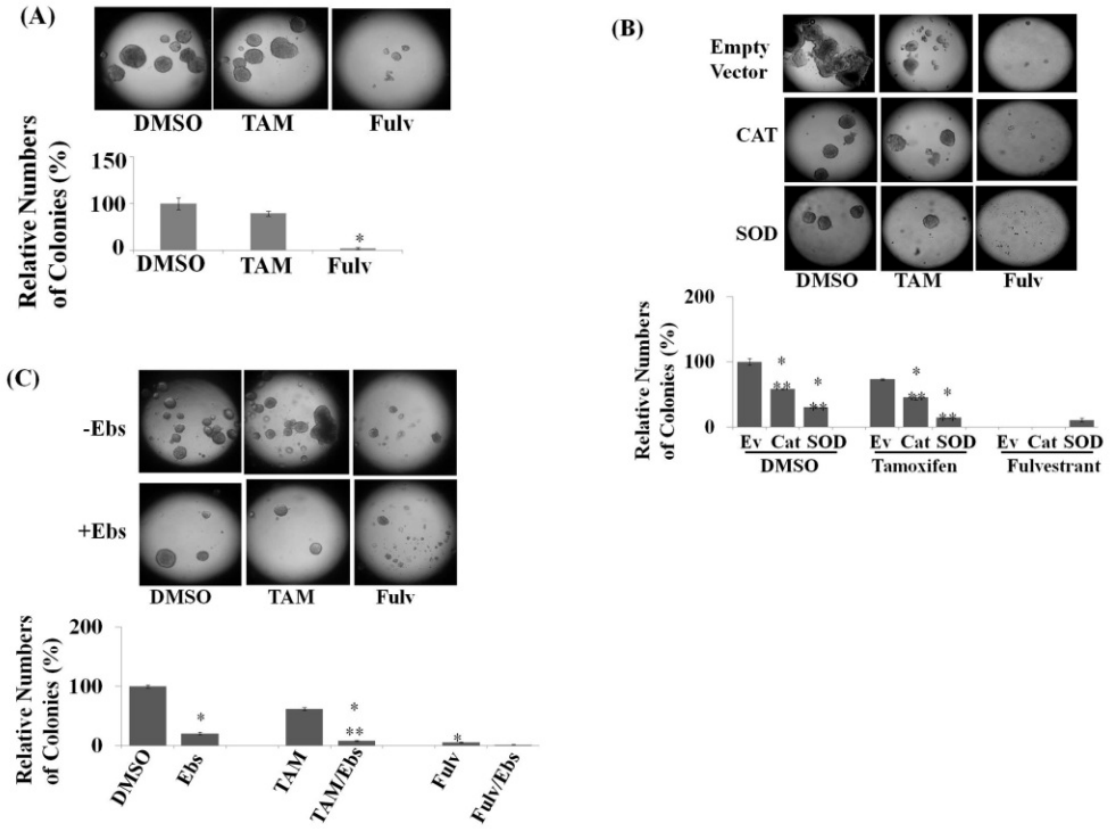

Antioxidants mitigate anchorage independent growth in TAM resistant LCC2 cells.

To determine the effect of antioxidants on anchorage-independent growth in TAM resistant cells, LCC2 cells were incubated on soft agar with or without antioxidants exposure for 21 days and colonies $\geq 60$ microns in diameter were enumerated. A) Anchorage independent growth of TAM resistant cells; B) LCC2 cells over expressing Catalase (CAT) or MnSOD (SOD); C) LCC2 cells pretreated with chemical antioxidant. Assay performed $3 \mathrm{x}$ and data is expressed as mean percentage change from control $+/-$ SE, $(p$ 0.05). (*) denote significance when treatment is compared to DMSO control while $(* *)$ indicates significance when compared to EV/DMSO control. 


\section{Fig 4-LCC2}
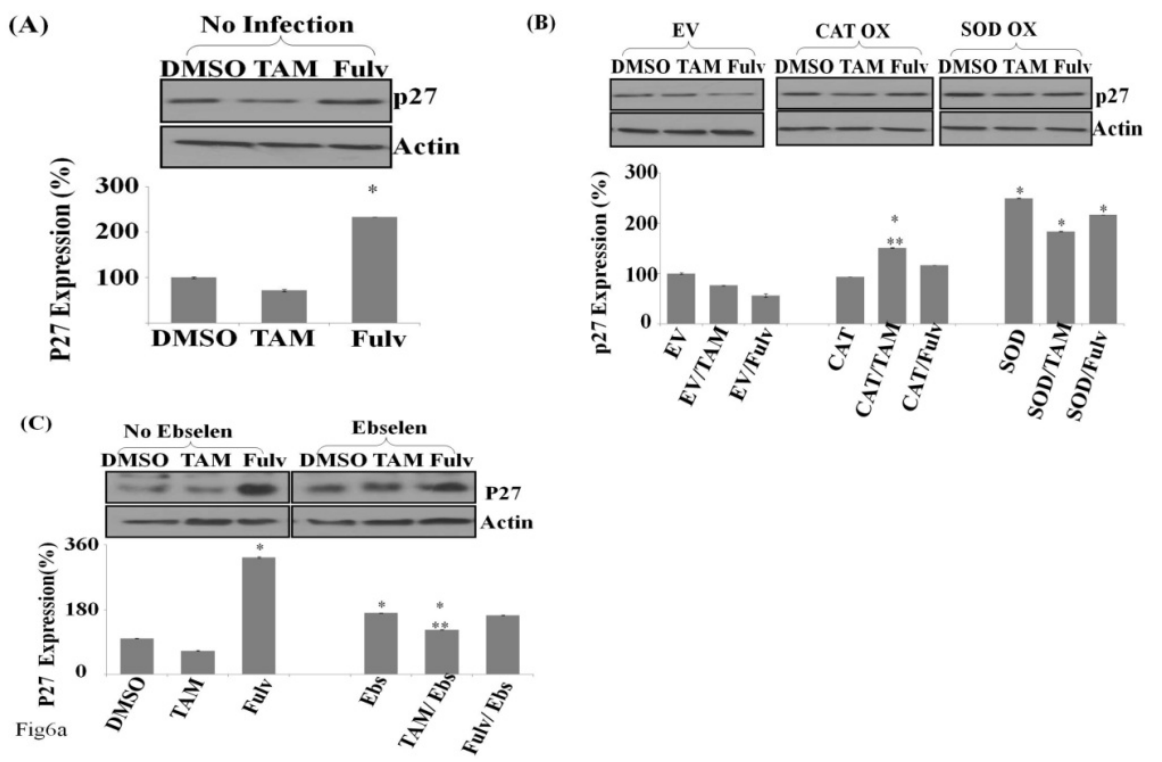

Antioxidants Increased p27 expression in TAM Resistant cells. LCC2 cells were exposed to antioxidants as described in methods and treated with TAM and fulvestrant respectively. After $48 \mathrm{hrs}$ incubations, cells were harvested with lysis buffer and $50 \mathrm{ug}$ whole cell lysate (WCL) were fractionated on 12\% SDS-PAGE gel. Immunoblots were probed with $\mathrm{p} 27$ or $\beta$ actin antibodies respectively. A) LCC2 cells treated with TAM or fulvestrant, B) LCC2 cells over expressing CAT or SOD, then treated with TAM and Fulv, C) LCC2 cells co-treated with chemical antioxidant and TAM or Fulv. Assay was performed 3x. P27 protein level was determined by densitometric analysis and expressed as the percentage mean of its ratio with $\beta$ actin relative to control $+/-\mathrm{SE},(p 0.05)$. denotes significance when treatment is compared to DMSO control while $(* *)$ indicates significance when compared to EV/DMSO control. 
Fig 5-LCC2
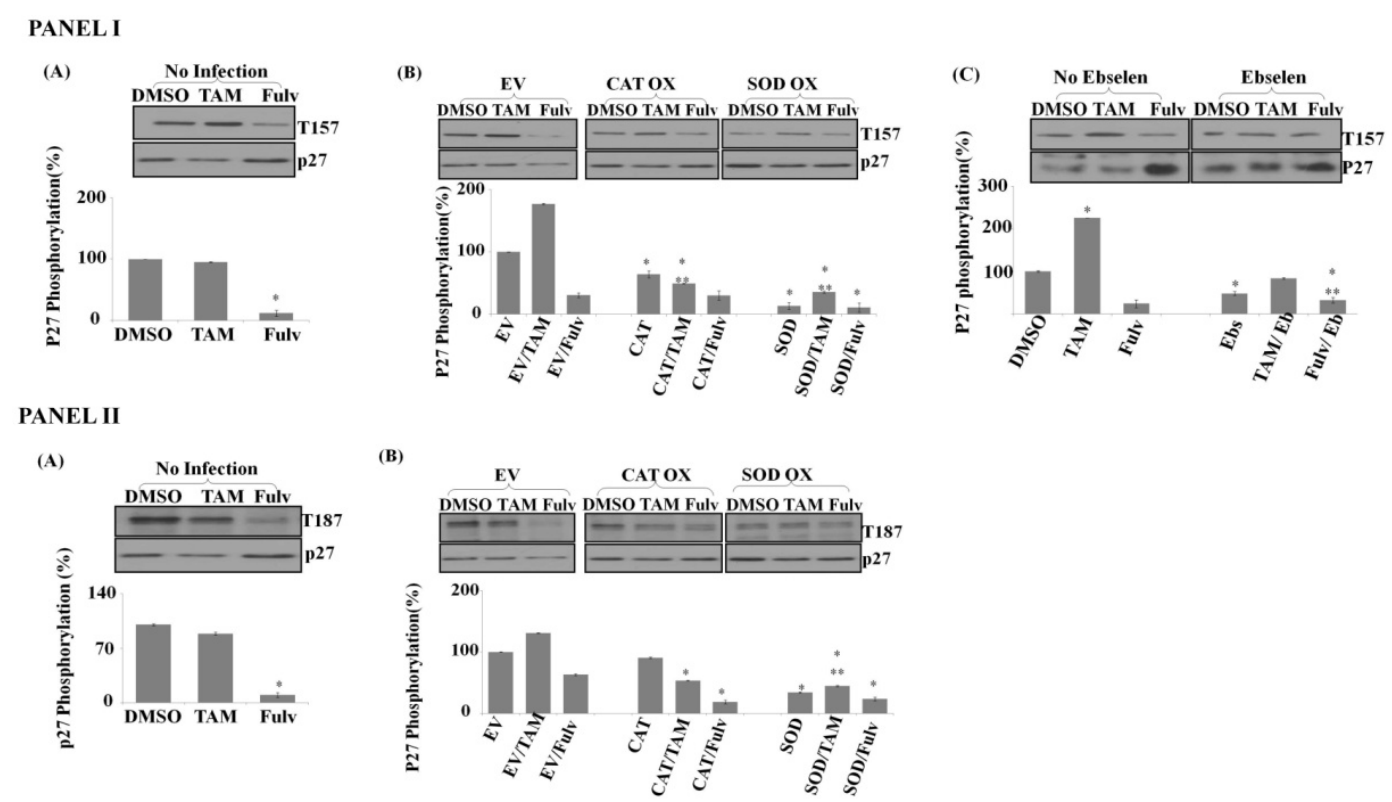

Antioxidants decreased p27 phosphorylation in TAM Resistant cells. (Panel I) A) LCC2 cells treated with TAM or Fulv and probed with p27 or p27 phosphorylated on Threonine 157 (T157); B) LCC2 cells over expressing CAT or SOD were treated with TAM and Fulv, then probed with p27 or T157; C) LCC2 cells co-treated with chemical antioxidant and TAM or Fulv, then probed with p27 or T157. (Panel 2) A) LCC2 cells treated with TAM or Fulv and probed with p27 or p27 phosphorylated on Threonine 187 (T187); B) LCC2 cells over expressing CAT or SOD were treated with TAM and Fulv, then probed with $\mathrm{p} 27$ or T187; C) LCC2 cells co-treated with chemical antioxidant and TAM or Fulv, then probed with p27 or T187. Assay was performed 3x. Phosphorylated p27 levels were determined by densitometric analysis and expressed as the percentage mean of their ratios to the ratio of $\mathrm{p} 27$ with $\beta$ actin relative to control $+/-\mathrm{SE},(p 0.05)$. is denotes significance when compared to DMSO control while $(* *)$ indicates significance when compared to EV/DMSO control. 
Fig. 6-LCC2

(A)

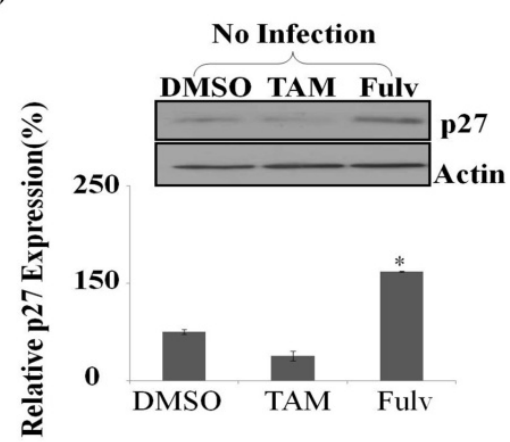

(B)

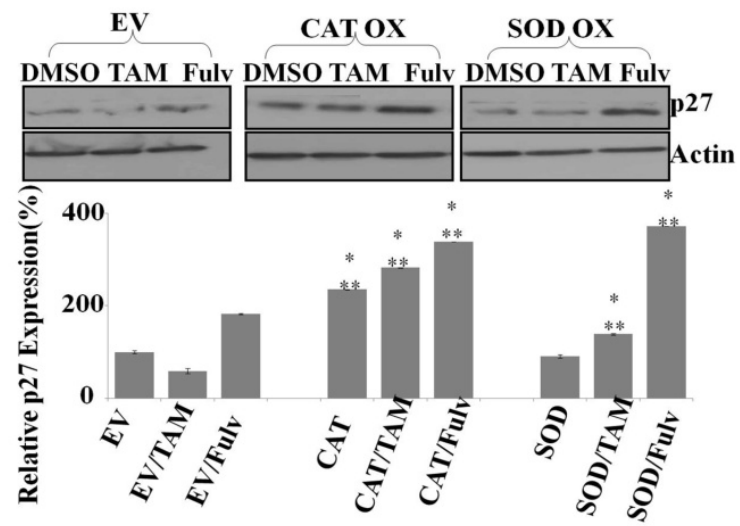

Prolonged antioxidant treatments increased p27 expression in LCC2 cells. LCC2 cells over expressing CAT or SOD were exposed to either TAM or Fulv for 21 days. A) Uninfected cells were treated with TAM or Fulv and probed for p27 and actin; B) CAT or SOD infected cells treated with TAM or Fulv and probed for p27 and $\beta$ actin. Assay was performed 3x. P27 protein level was determined by densitometric analysis and expressed as the percentage mean of its ratio with $\beta$ actin relative to control $+/-\mathrm{SE},(p 0.05) .\left(^{*}\right)$ denotes significance when treatment is compared to DMSO control while $(* *)$ indicates significance when compared to EV/DMSO control. 


\section{Fig 7-LCC2}

PANEL I

(A)

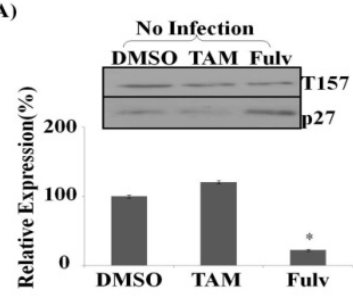

PANEL II

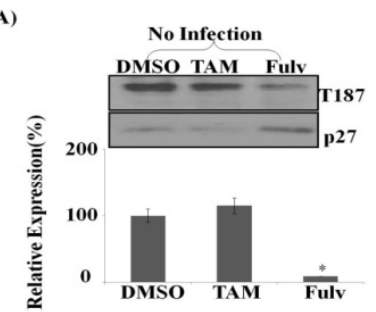

(B)

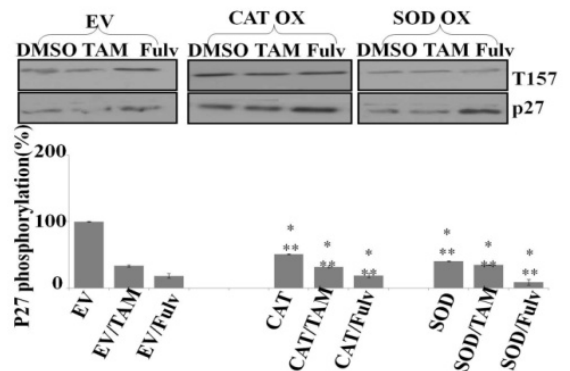

(B)

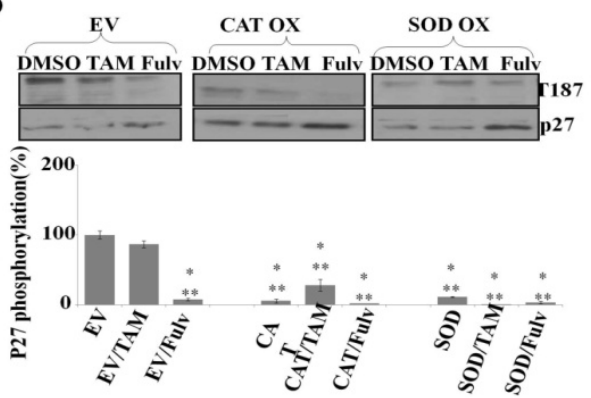

Prolonged exposure of LCC2 cells to Antioxidants decreased p27 phosphorylation in

LCC2. (Panel I) A) LCC2 cells treated with TAM or Fulv for 21 days and probed with p27 or T157; B) LCC2 cells over expressing CAT or SOD were treated with TAM and Fulv for 21 days, and then probed with p27 or T157. (Panel II) A) LCC2 cells treated with TAM or Fulv for 21 days and probed with p27 or T187; B) LCC2 cells over expressing CAT or SOD were treated with TAM and Fulv for 21 days, and then probed with p27 or T187. Assay was performed 3x. Phosphorylated p27 levels were determined by densitometric analysis and expressed as the percentage mean of their ratios to the ratio of p27 with $\beta$ actin relative to control $+/-\mathrm{SE},(p 0.05)$. (*) denotes significance when compared to DMSO control while $(* *)$ indicates significance when compared to EV/DMSO control. 
Fig 8-LCC2.
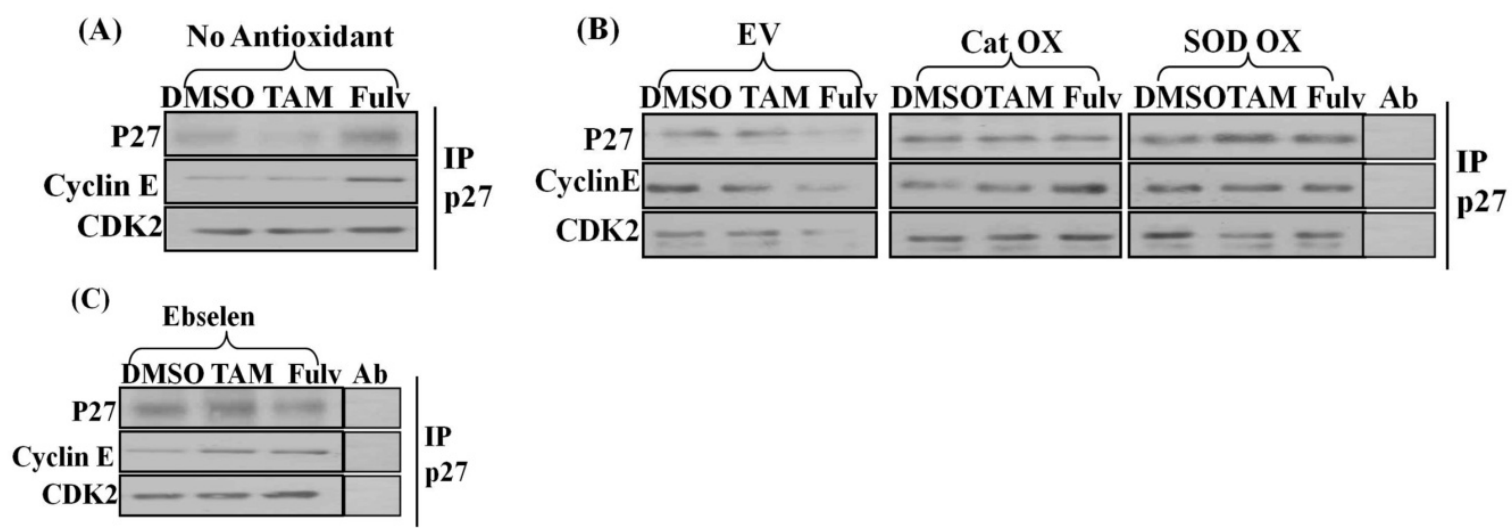

Antioxidant Increased p27 binding to CylinE and CDK2 in TAM resistant cells. LCC2 were exposed to antioxidants as described in methods and treated with TAM and fulvestrant respectively. After 48 hrs incubations, cells were harvested with lysis buffer and 350 ug WCL was immunoprecipitated (IP) with p27 antibody using Exactacruz kit as recommended. Eluent was fractionated on 12\% SDS-PAGE gel. Immunoblots were probed with p27, CDK2 or CyclinE antibodies respectively. A) LCC2 cells treated with TAM or Fulv, B) LCC2 cells over expressing CAT or SOD, then treated with TAM and Fulv, C) LCC2 cells co-treated with chemical antioxidant and TAM or Fulv. 
Fig 9- LCC2
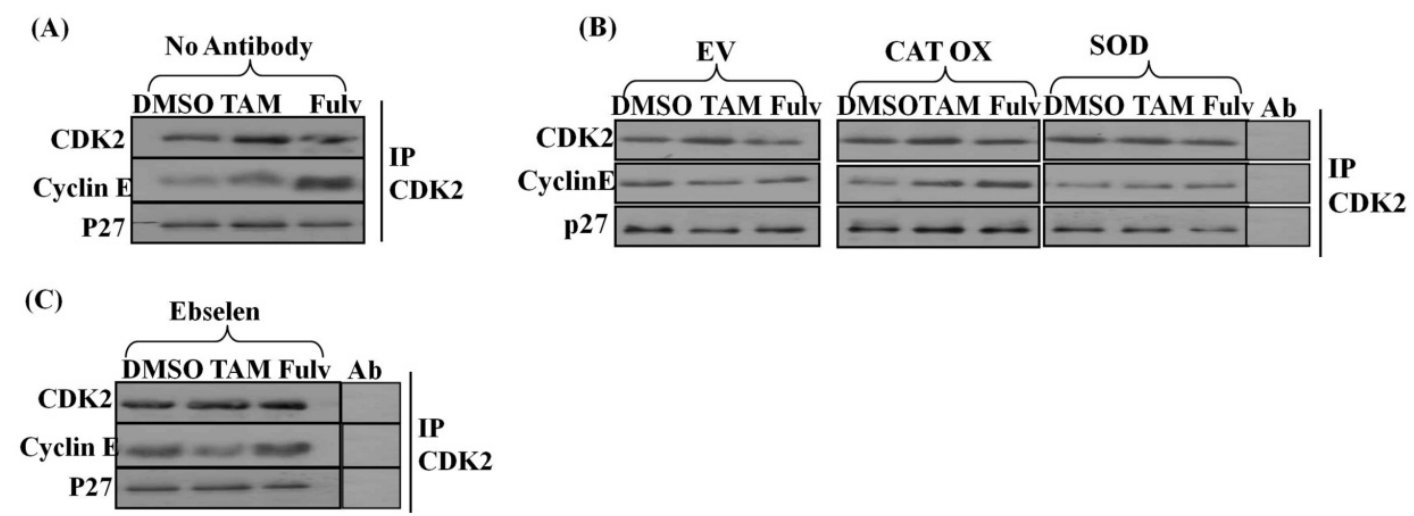

\section{Antioxidants Increased CDK2 binding to CylinE and p27 in TAM resistant cells.}

LCC2 were exposed to antioxidants as described in methods and treated with TAM and fulvestrant respectively. After 48 hrs incubations, cells were harvested with lysis buffer and 350 ug WCL was immunoprecipitated (IP) with CDK2 antibody using Exactacruz kit as recommended. Eluent was fractionated on 12\% SDS-PAGE gel. Immunoblot were probed with, CDK2, p27 or CyclinE antibodies. A) LCC2 cells treated with TAM or Fulv, B) LCC2 cells over expressing CAT or SOD, then treated with TAM and Fulv, C) LCC2 cells co-treated with chemical antioxidant and TAM or Fulv. 


\section{Fig10-LCC2}
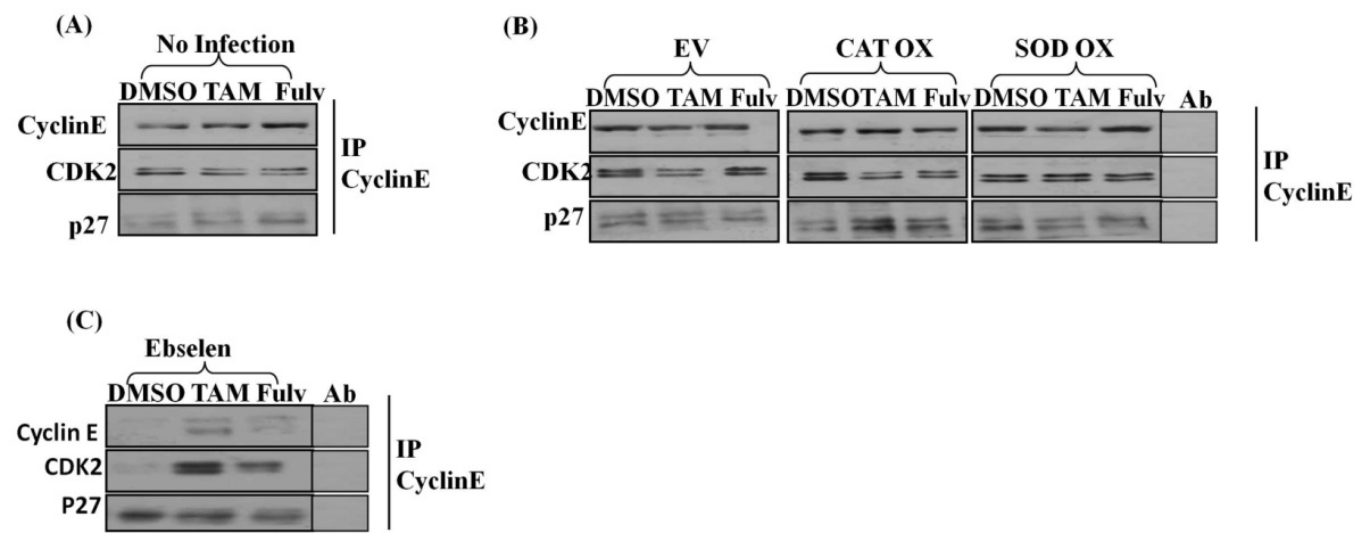

\section{Antioxidant Increased CylinE binding to CDK2 and p27 in TAM resistant cells.}

LCC2 were exposed to antioxidants as described in methods and treated with TAM and fulvestrant respectively. After 48 hrs incubations, cells were harvested with lysis buffer and 350 ug WCL was immunoprecipitated (IP) with CDK2 antibody using Exactacruz kit as recommended. Eluent was fractionated on 12\% SDS-PAGE gel. Immunoblots were probed with, CyclinE, p27 or CDK2, antibodies respectively. A) LCC2 cells treated with TAM or Fulv, B) LCC2 cells over expressing CAT or SOD, then treated with TAM and Fulv, C) LCC2 cells co-treated with chemical antioxidant and TAM or Fulv. 
Fig11-LCC2

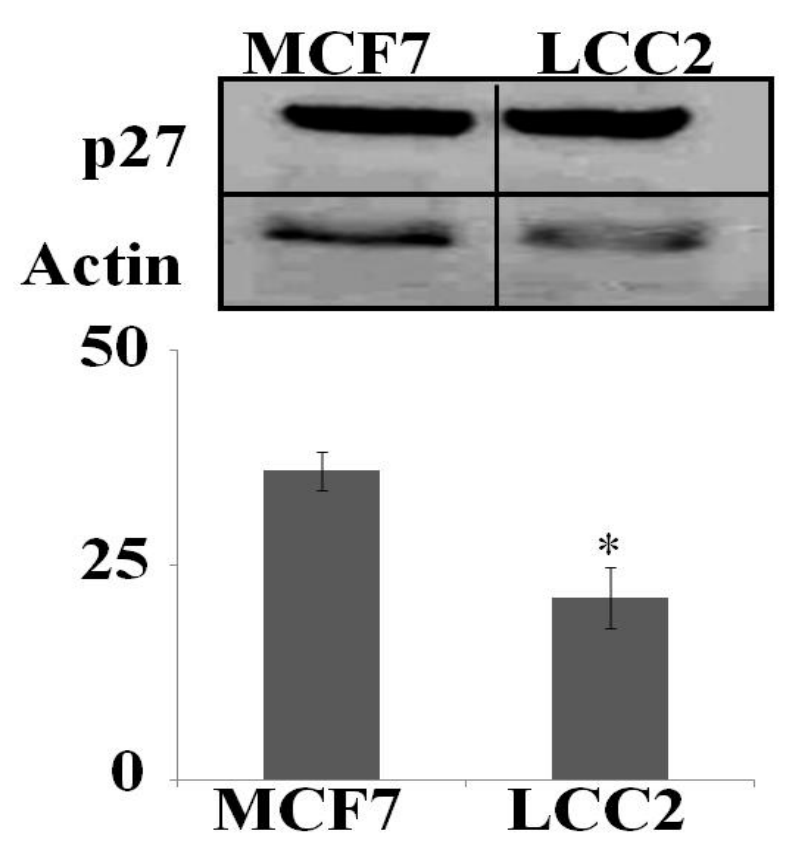

P27 expression is less in LCC2 cells compared to MCF7. 1million LCC2 and MCF7 cells were seed and serum starved for 48 hours after which cells were harvested with lysis buffer and 50 ug whole cell lysate (WCL) were fractionated on 12\% SDS-PAGE gel. Immunoblot were probed with p27 or beta actin antibodies respectively. Figure shows p27 and Actin expression in LCC2 and MCF7 cells. Assay was performed 3x. P27 protein level was determined by densitometric analysis and expressed as the percentage mean of its ratio with $\beta$ actin relative to control $+/-\mathrm{SE},\left(p 0.05\left(^{*}\right)\right.$ is indicates significance when p27 expression in LCC2 cells is compared to that of MCF7 cells. 
Fig12-LCC2
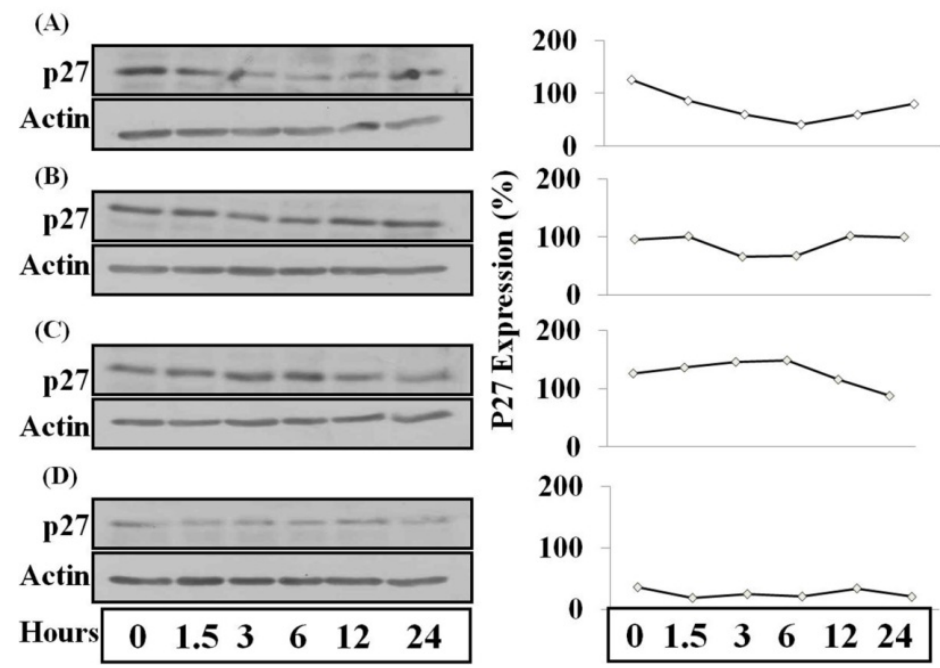

Antioxidants increased p27 stability. Uninfected LCC2 cells (A) and LCC2 cells over expressing CAT(B), SOD(C) or EV(D) were treated with 50uM cycloheximide (CHX) for the time periods indicated, and p27 protein levels were determined by immunoblotting and densitometry with $\beta$ actin as internal control.

\title{
IV ESTROGEN INDUCED ROS MEDIATES IN VITRO CELL PROLIFERATION AND GROWTH THROUGH PTEN OXIDATION AND AKT- NRF-1 PHOSPHORYLATION
}

\begin{abstract}
Tamoxifen resistance is still a significant problem in the treatment of estrogen receptor positive breast cancer. Due to de novo resistance, only about $70 \%$ of breast cancer patients will initially respond to tamoxifen treatment. About $40 \%$ of patients who were initially responsive to the drug and majority of the patients with metastatic breast disease
\end{abstract}


will develop an acquired resistance to the drug over time. Although there has been an improvement in our understanding of the subject, the molecular mechanism(s) that result in the evolution of tamoxifen resistant breast cancer is still unclear. In this study we explored the role of reactive oxygen species (ROS) in the advancement of breast cancer from a tamoxifen-sensitive to a tamoxifen-resistant phenotype. ROS are products of cellular metabolism and an excessive and/or sustained increase in their production has been implicated in the pathogenesis of cancer. Furthermore, ROS induces oxidative stress which has been shown to initiate various cellular responses including alteration of intracellular redox state and the oxidative modification of certain signaling proteins resulting in the post translational modification of their downstream targets. Interestingly, tamoxifen like estrogen, has been shown to induce ROS formation, making it probable that tamoxifen induced ROS generated as a result of prolong tamoxifen treatment of breast cancer patients may play a critical role in the development of its resistance. Using MCF7 breast cancer cells and standard laboratory techniques, we explored the role of ROS and redox signaling in development of tamoxifen resistance in breast cancer cells. We were interested in finding out how and if ROS, through the oxidation of Phosphatase and tensin homolog (PTEN) induces the phosphorylation and activation of nuclear respiratory factor 1(NRF-1) resulting in its binding to the promoter region of certain cell cycle genes, thereby promoting cell proliferation and a transformation of the cells to a resistant phenotype. We also wanted to find out if this process can be reversed by preexposing the cells to biological or chemical antioxidants. Our finding was that, tamoxifen-induced ROS oxidizes PTEN resulting to the hyper-stimulation of the Akt/PI3K pathway and a consequent NRF-1 phophorylation/activation. Activated NRF-1 
then binds to the promoter region of some cell cycle genes inducing cell proliferation. We also found that pre-treating the cell with anti-oxidants restored sensitivity to tamoxifen.

\section{Introduction}

PTEN (phosphatase and tensin homologue deleted from chromosome 10) is a redox sensitive dual specificity phosphatase ${ }^{1}$. It is a known tumor suppressor because of its ability to regulate the cell cycle either by preventing cells from dividing too fast or dividing in an uncontrolled manner ${ }^{2}$ such as that seen in cancer cells. The protein which is a negative-regulator of the phosphatidylinositol 3-Kinase (PI3K)/Akt pathway acts by dephosphorylating phosphatidyl-inositol3,4,5-trisphosphate $(\mathrm{PI}(3,4,5) \mathrm{P} 3)$ at the 3 ' position of the inositol ring, thereby counteracting the effect of PI3K and inactivating this key player in the survival pathway ${ }^{3}$.

The tumor suppressor aspect of PTEN function is pertinent in the context of human disease since a number of studies have found PTEN deficiency, which could arise either by polymorphic mutation or gene deletion, to be a cause of cancer ${ }^{4,5}$. Indeed one of the reasons for the activation of Akt signaling in cancers is the mutation or inactivation of PTEN ${ }^{6}$. However, PTEN inactivation and the resulting PI3K/Akt pathway hyperactivation could occur through mechanisms other than those that target the integrity of the gene ${ }^{7}$.

Alternate mechanisms of the down regulation of PTEN activity by posttranslational modifications such as phosphorylation and oxidation, though not directly implicated in 
cancer, have been documented ${ }^{8-11}$. Furthermore, reactive oxygen species (ROS) have been shown to oxidize PTEN at its active site ensuing in the formation of a disulphide bond and a subsequent PTEN inactivation. Several studies have demonstrated the ability of reactive oxygen species to reversibly oxidize PTEN and other dual specificity phosphatases, leading to their temporary inactivation ${ }^{12-13}$. Indeed a number of studies have looked into the temporary inactivation of PTEN by ROS and its effect on downstream molecules like Akt and its substrates. For example Connor et al and others have shown that PTEN oxidation enables PtdIns(3,4,5)P3 to directly activate Akt, which in turn activates p70 S6 kinase and inhibits the Akt substrate, glycogen synthase kinase-3 thereby regulating cellular metabolism and the cell cycle ${ }^{13,14}$.

A less well known Akt substrate is NFF1 (nuclear respiratory factor-1/ $\alpha$-palindromebinding protein) ${ }^{15}$ which is a redox sensitive transcription factor ${ }^{16}$ that has been shown to regulate metabolism and cell proliferation ${ }^{17-20}$. A study by Piatandosi and Suliman (2006), has demonstrated how stimulation of PI3K by exogenous oxidants activate Akt and promotes NRF1 phosphorylation and nuclear translocation ${ }^{15}$. Additionally, it has been shown that exposure of breast cancer cells to estrogen (E2) induces cell growth ${ }^{21}$ and an increase in NRF1 expression ${ }^{22}$. Since estrogen has been shown to promote ROS formation ${ }^{23}$, we considered it pertinent to examine a hitherto unexplored possibility that E2-induced ROS could result in PTEN inactivation, a consequent increase in NRF1 expression and phosphorylation and an effect on the cell cycle. In the event of this concept being cogent, we also wanted to determine the effect of antioxidants on our proposed pathway. 
In this study, we show how estrogen induced PTEN oxidation in MCF7 results in the hyper-activation of the PI3K/Akt signaling pathway with a consequent increase in the expression and phosphorylation of NRF1 and a resultant binding of NRF1 to the promoter region of cell cycle genes. We also show how pre-exposing MCF7 cells to antioxidants is able to reverse the PTEN oxidation and its downstream effects.

\section{Materials and methods}

\section{Cell culture and Materials}

MCF7 cells were obtained from Gainsville. Cells were cultured in DMEM (Gibco) containing $10 \%$ fetal bovine serum, 25,000 units of penicillin (base) and 25,000 $\mu \mathrm{g}$ of Streptomycin at $37^{\circ} \mathrm{C}$ in a fully humidified atmosphere of $5 \% \mathrm{CO} 2$ in air. For experiments, $70 \%$ Confluent cells were further cultured in serum free DMEM to minimize the effect of serum and synchronize the cells in G0. Synchronized cells were always stimulated with $0.01 \%$ DMSO or $100 \mathrm{pg}$ E2.

Antibodies to NRF1 was obtained from Rockland, PTEN was obtained from cell signaling while p27, AKT and PAKT ser 473 were purchased from Santa Cruz biotechnology. T157 Phosphorylated p27 antibody was purchased from Abcam. Beta Actin, 2', 7'-dichlorodihydrofluorescein diacetate (DCFH-DA), DMSO and Ebselen were purchased from Sigma Aldrich. BrdU kit was purchased from ROCHE. Protein A Agarose was purchased from Invitrogen. The adenoviruses AdEmpty (EV), AdMnSOD (SOD), and AdCatalase (CAT) were manufactured at ViraQuest, Inc. (North Liberty, IA, USA). Primers for CyclinB1, CDC2, CDC25C, PRC1and PCNA where purchased from 
Applied Biosystems. The Upstate kit for ChIP assay was purchased from upstate biotechnology.

\section{Adenoviral Transduction}

The adenoviruses AdEmpty (EV), AdMnSOD (SOD), and AdCatalase (CAT) were manufactured at ViraQuest, Inc. (North Liberty, IA, USA) by inserting either nothing (EV) or the MnSOD or Catalase gene into the E1 region of an Ad5 E1/partial E3-deleted replication-deficient adenoviral vector.

MCF7 cells were plated in $100-\mathrm{mm}$ dishes at a density of $1 \times 10^{6}$ cells/dish in charcoal stripped medium. The following day, the medium was aspirated and replaced with $5 \mathrm{ml}$ of serum-free medium containing 200pfu of SOD, CAT or EV adenovirus for 24hours after which cells were stimulated with required treatments for the desired amount of time.

\section{Ebselen Pre-treatment}

1million MCF7 cells were plated per $100 \mathrm{~mm}$ dish in $10 \%$ serum medium. 21 hours post seeding 20uM of Ebselen was added to the medium for 3hours after which cells were stimulated with the desired treatments for 24 hours. 


\section{BrdU Incorporation Assay}

For BrdU incorporation, MCF7 cells were seeded in 96-well plates at a density of $2500 /$ well and incubated in $5 \% \mathrm{CO} 2$ incubator at $37^{\circ} \mathrm{C} .24$ hours after seeding, cells were either infected with AdCatalase, AdMnSOD or AdEV at a multiplicity of infection (m.o.i) of 290pfu/cell as described above or pre-treated with $40 \mathrm{uM}$ of Ebselen. After exposure to antioxidants cells were then stimulated with either $0.01 \%$ DMSO or E2 (100pg) for 24hours. After stimulation, BrdU incorporation was carried out using Roche Bioscience (Cell Proliferation ELISA, BrdU Kit; Roche Molecular Biochemical, Indianapolis, IN) labeling kit in accordance with manufacturer's recommendation. Colorimetric changes acquired at $370 \mathrm{~nm}$ with a Tecan Genios microplate reader.

\section{2', 7'-dichlorofluorescin diacetate (DCFH-DA)}

To carry out the DCFH-DA Assay, 10,000/well of MCF7 cells were seeded in a 96-well plate and cultured in $10 \%$ growth medium for 24 hours. After 24 hours growth medium was aspirated and replaced with starvation medium for another 24 hours after which the starvation media was aspirated and replaced with 100uL/well of HBSS containing 10uM DCFDA pre-diluted with Pluronic F-127 and incubated at $37 \mathrm{oC}$ for $20 \mathrm{mins}$. At the end of the incubation, DCFH-DA solution was gently aspirated and pre-designated wells were then stimulated with $100 \mathrm{ul}$ of HBSS containing either $0.01 \%$ DMSO (vehicle control) or E2 (100pg). Cells were further incubated for $5 \mathrm{mins}$ after which fluorescence readings were taken using $485 \mathrm{~nm}$ and $535 \mathrm{~nm}$ as excitation and emission filters, at intervals of 5mins. Optical density readings were obtained using a Tecan Genios microplate reader. 


\section{Westernblot}

1 million MCF7 cells per 100mm dish were initially exposed to antioxidants as described above and then stimulated with either $0.01 \%$ DMSO, or E2 30mins. Post treatment, cells were harvested and lysed in radioimmunoprecipitation assay buffer $[25 \mathrm{mM}$ Tris $\mathrm{HCl}(\mathrm{pH}$ 7.4), $25 \mathrm{mM} \mathrm{NaCl}, 1 \mathrm{mM}$ sodium orthovanadate, $10 \mathrm{mM}$ sodium pyrophosphate, $10 \mathrm{mM}$ NaF, $0.5 \mathrm{mM}$ EGTA, 1.0\% Triton X-100, $1 \mathrm{mM}$ PMSF, and $10 \mathrm{mM}$ okadaic acid] for 15 min on ice. Samples were then briefly sonicated and centrifuged at 10,000rpm for $10 \mathrm{~min}$ at $4^{\circ} \mathrm{C}$. The total protein concentration of the resulting supernatant was determined by BCA quantification. Equal amount of protein extracts (50ug) were separated by SDSPAGE, transferred to a polyvinylidene difluoride membrane, blocked in $1 \%$ BSA and fat free milk solution containing 50mM NAF for 1hour and blotted with antibodies. Labeled proteins are visualized with an ECL system (Amersham Biosciences). Band intensity was determined using densitometric analysis (NIH ImageJ software). The level of protein level was expressed as its ratio to $\beta$ actin.

\section{Soft Agar Colony Formation Assay.}

To assess the effect of antioxidants on anchorage-independent cell growth, a soft agar colony formation assay using either plain or Ebselen pretreated MCF7 cells was performed. MCF7 cells (1000/well) were suspended in $0.2 \mathrm{ml}$ of charcoal stripped culture medium containing $0.25 \%$ agar and appropriate treatment $(0.01 \% \mathrm{DMSO}, 100 \mathrm{pg} \mathrm{E} 2$, luM Tamoxifen, or co-treatment of TAM with E2 ) and poured over a pre-hardened

feeder layer of agarose comprising $0.2 \mathrm{ml}$ of the charcoal stripped medium, containing $0.5 \%$ agar, in a 48 well plate. Cells were fed every 4 days and allowed to incubate for 
30days. After 14 days of incubation at $37^{\circ} \mathrm{C}$ in a humidified $\mathrm{CO} 2$ incubator, colonies counted excluding any colonies with a diameter $\leq 60$.

\section{Identification of Reduced and Oxidized Forms of PTEN by Immunoblot Analysis.}

After stimulation, I million/100mm dish of MCF7 cells in $1 \mathrm{ml}$ of HBSS were scraped into $0.2 \mathrm{ml}$ of ice-cold $50 \%$ trichloroacetic acid and transferred to microfuge tubes. The cell suspensions were sonicated briefly and then centrifuged at $2000 \mathrm{~g}$ for $5 \mathrm{~min}$. The supernatants were removed, and the pellets were washed with acetone and then solubilized in $0.2 \mathrm{ml}$ of $100 \mathrm{mM}$ Tris- $\mathrm{HCl}(\mathrm{pH} 6.8)$ buffer containing 2\% SDS and 40 $\mathrm{mM}$ NEM. 5ul of the solubilized pellets were subjected to SDS-PAGE under nonreducing conditions, and the separated proteins were transferred electrophoretically to a polyvinylidene difluoride membrane.

The membrane was then subjected to immunoblot analysis with either rabbit antibodies to PTEN or monoclonal antibody to Beta Actin. Immune complexes were detected with horseradish peroxidase-conjugated secondary antibodies and enhanced chemiluminescence reagents (Amersham Biosciences). The intensity of PTEN bands was quantitated with NIH ImageJ.

\section{Chromatin Immunoprecipitation (ChIP) Assay}

This assay was carried out using the upstate protocol that came with the kit. Briefly, after stimulation, protein complex was cross-linked to DNA by adding formaldehyde directly to culture medium to a final concentration of $1 \%$ and incubate for 10 minutes at $37 \mathrm{C}$. Cells were washed twice with ice cold PBS containing protease inhibitors scraped into 
conical tube and Pelleted for 4 minutes at $2000 \mathrm{rpm}$ at $4^{\circ} \mathrm{C}$. Cell pellet was then lysed in SDS Lysis buffer for 10 minutes on ice. Lysate was sonicated (5 x 15pulses) and centrifuged for 10 minutes at $13,000 \mathrm{rpm}$ at $4^{\circ} \mathrm{C} .150 \mathrm{ul}$ of the sonicated cell pellet suspension was transferred to a new $1.5 \mathrm{ml}$ eppendorf tube and diluted 10times in ChIP

Dilution buffer containing protease inhibitors. 1\% ( 15 ul $)$ was kept aside as input/starting material. $1.5 \mathrm{ml}$ diluted cell pellet suspension was pre-cleared with $60 \mathrm{ul}$ of Salmon Sperm DNA/Protein A Agarose-50\% slurry for 2 hours at $4^{\circ} \mathrm{C}$ with agitation. Agarose was pelleted by brief centrfugation (1min @ 1000rpm). The supernatant fraction was collected and the immunoprecipitating antibody added to the $1.5 \mathrm{ml}$ supernatant fraction and incubate overnight at $4^{\circ} \mathrm{C}$ with rotation. A non-specific antibody for immunoprecipitation as negative control. $40 \mathrm{ul}$ of Salmon Sperm DNA/Protein A Agarose Slurry was added for another two hour at $4^{\circ} \mathrm{C}$ with rotation to collect the antibody/protein complex. Agarose was then pelleted, supernatant was discarded and washed with different wash buffers for 3-5minutes per wash. The histone complex was then eluted from the antibody and all samples including the input were reverse crosslinked by heating at $65^{\circ} \mathrm{C}$ for 6 hours. DNA was then recovered by ethanol precipitation and PCR analysis performed.

\section{Immunofluorescence Labeling}

Cells were seeded $\left(1.0 \times 10^{4}\right.$ cells/chamber) and stimulated in chamber slides as indicated in the legends of the figures. After treatment, cells were fixed with ice cold methanol for $15 \mathrm{mins}$, and permeabilized with $0.5 \%$ Triton $\mathrm{X}-100$ for $30 \mathrm{~min}$. Then the cells were blocked with $1 \%$ normal goat sera for $1 \mathrm{hr}$ after which they were probed simultaneously 
with antibodies diluted 1: 500 for NRF1; or 1:1500 for phosphor serine. Alexa Fluor labeled secondary antibodies directed against primary antibodies was diluted 1:1000. The confocal fluorescence images were scanned on a Nikon TE2000U inverted fluorescence microscope equipped with a Nikon D-Eclipse C1 laser scanning confocal microscope system (Nikon Corp., USA). The z-series scanning were done at every $1 \mu \mathrm{m}$ up to a $\mathrm{z}$ depth of $10 \mu \mathrm{m}$ by using a Nikon 40 x 1.30 NA DIC H/N2 Plan Fluor oil immersion objective. The built-in Nikon EZ-C1 software was used for confocal image acquisition and analyses.

\section{Results}

Estrogen induces ROS in MCF-7. To determine whether E2 induces ROS in breast cancer cells, MCF-7 cells were treated with either E2 or E2 with ROS modulators as described in methods. Results showed that cells exposed to E2 induced ROS formations (Fig.1A). However, co-treatment of cells with E2 and ROS modulators (CAT or Eb) inhibited estrogen's ability to induce ROS formations (Fig.1B).

\section{Estrogen induced ROS mediates in vitro proliferation and growth of MCF-7 cells.}

To ascertain whether E2 induced ROS facilitates in vitro proliferation and growth of breast cancer cells, MCF-7 cells were seeded for BrdU and soft agar assay as described in methods. Cells were subsequently treated with E2 or E2 and ROS modulators. BrdU incorporation, which is a marker of cells proliferation and soft agar colony formation, which is a hallmark of anchorage independent cancer growth, were analyzed and enumerated as described in methods and legends. Data indicate that E2 induced 
proliferation of MCF-7 cells were abrogated by ROS modulators (Fig 2). Similarly, E2 induced anchorage independent growth of breast cancer cells were abolished by ROS modulators (Fig 3). These findings indicate that estrogen induced proliferation and growth of breast cancer cells are redox dependent.

Estrogen induced ROS oxidizes PTEN in MCF-7 cells. Oxidation of PTEN by ROS has been demonstrated to promote carcinogenesis and growth of cancer cells (PMID: 15534200). We investigated whether E2 induced ROS also oxidizes PTEN thereby promoting E2 induced proliferation and growth of breast cancer cells. Western blot analysis indicates that while $\mathrm{H} 2 \mathrm{O} 2$ are potent oxidizers of PTEN (Fig. 4), E2 induced ROS can similarly oxidize PTEN albeit to a lesser extent compared to H2O2 (Fig. 5A). However, when cells were co-treated with either Catalase or Ebselen, E2 induced PTEN oxidation were significantly reversed (Figs. 5B \& C). These findings indicates that E2 induced ROS can lead to PTEN oxidation which could alter downstream signaling process that favors breast cancer proliferation and growth in response to estrogens.

\section{Estrogen induced PTEN oxidation activates Akt phosphorylation in MCF7 cells.}

Western blot analysis were carried out to determine whether E2 induced PTEN oxidation would lead to increased Akt activation and whether ROS modulators would attenuate Akt activation in E2 treated breast cancer cell. Our study showed that E2 induced significant Akt phosphorylation compared to vehicle treated cells (Fig. 6A). When cells were cotreated with E2 and ROS modulators, Akt activations were significantly reduced (Figs.6B\&C). This data indicates that E2 induced PTEN inactivation and activation of 
Akt signaling cascade in breast cancer cells are redox dependent. Activated Akt can in turn phosphorylate downstream substrates such as transcription factors that favor survival and growth of breast cancer cells.

Estrogen induces NRF1 expression and phosphorylation in MCF7 cells. To determine the effect of Estrogen induced PTEN oxidation on downstream Akt signaling substrates, Immunohistochemistry assays were carried out to determine how E2 induced ROS affect NRF1 expression and phosphorylation. Results show an increase in NRF1 expression and phosphorylation in E2 treated cells compared to DMSO control (Fig.7).

\section{Estrogen induced ROS mediates NFR-1 binding to promoter regions of cell cycle} genes in MCF7 cells. A chromatin immunoprecipitation assay was carried out to determine the effect of E2 on NRF1 binding as described in methods. Result obtained shows an E2 induced increase in NRF1 binding to the promoter region of the following cell cycle genes: CyclinB1, CDC2, PCNA, CDC25C and PRC1 (Fig. 8, Panels I \&IIA). Conversely, Antioxidant pre-treatment significantly inhibited the E2 induced NRF1 binding to the promoter region of the same genes (Fig. 8, Panels I \&IIB).

Estrogen induced ROS mediates transcription of Cell cycle genes. RT-PCR was carried out to determine the effect of E2 induced ROS on the transcription of cell cycle genes as shown in methods. Result obtained show an up-regulation in the transcription of CyclinB1, PCNA, CDC25C and PRC1 (Fig.9, Panels I\&IIA). However, when cells were 
co-treated with either $\mathrm{CAT}$ or $\mathrm{Eb}$, there was a significant inhibition of E2 induced transcription upregulation of the same genes (Fig.9, Panels I\&IIB).

\section{Discussion}

The results of our study show that estrogen-induced reactive oxidants have the capacity to stimulate cell proliferation in MCF7 breast cancer cells through the oxidation of PTEN, and the post translational modification of its downstream target.

In line with previous work done ${ }^{23}$, we are able to show here that estrogen-induced reactive oxygen species (ROS) is capable of promoting DNA synthesis and cell proliferation, which can be inhibited by exposure of the same cells to either biological or chemical antioxidants, Catalase or Ebselen (See figs. 1, 2 and 3).

In this study, we have been able to show for the first time in MCF7 cells that estrogeninduced ROS oxidizes PTEN within 30 minutes of exposure. In addition, we reveal herein the ability of either Catalase or Ebselen to reverse the oxidizing effect of estrogeninduced ROS. See figs.4 and 5. We also show here that estrogen-induced PTEN inactivation in MCF7 cells results in an increase in the phosphorylation of one of its downstream target kinases, Akt. This is in line with previous studies which showed an increase in Akt phosphorylation following PTEN inactivation by agents other than

estrogen ${ }^{13,24,25}$. Moreover, we have also been able show that the pre-exposure of MCF7 cells to either Catalase or Ebselen significantly reverses the E2-induced effect. See fig.6. Also demonstrated in this study is a corresponding increase in both the expression and 
phosphorylation of NRF1, which is a known Akt substrate that has been implicated in cell growth and proliferation ${ }^{18-20}$. (See figure 7 ).

Based on the work done by Cam et al. ${ }^{18}$, which showed NRF1 could collaborate with E2F family members to regulate the expression of genes that are involved in cellular proliferation, we explored the possibility of phosphorylated (active) NRF1 binding to the promoter region of cell cycle genes. Evident in our study for the first time in MCF7 cells, is an increase in the binding of Akt phosphorylated NRF1 to the promoter region of the following cell cycle genes: CyclinB1; CDC25A; CDC2; PCNA and PRC1. It is also worthy of mention that this promoter binding was significantly inhibited by the preexposure of MCF7 cells to either Catalase or manganese superoxide dismutase (MnSOD). See fig. 8. We were further able to reveal a consequent increase, in the transcription of these gene, which was also inhibited by pre-exposure to Catalase and MnSOD (See fig. 9).

In summary we have been able to show for the first time in MCF7 cells, that estrogeninduced ROS inactivates PTEN with an ensuing increase in Akt phosphorylation. This Increase in Akt phosphorylation results in an increase in NRF1 expression and phosphorylation leading to the activation and binding of NRF1 to the promoter region of some cell cycle genes, namely CyclinB1, CDC25A, CDC2, PCNA and PRC1 leading to cell proliferation. We also show a corresponding increase in the transcription of these genes. Additionally, we show for the first time that that pre-exposure of MCF7 cells to 
either biological or chemical antioxidants significantly inhibited the effect of estrogeninduced ROS on PTEN and its downstream substrates (See fig. 10).

\section{References}

(1) De Vivo, I., Gertig, D., Nagase, S., Hankinson, S.E., OBrien, R., Speizer, F.E., Parsons, R. and Hunter, D.J. Novel germline mutations in the PTEN tumour suppressor gene found in women with multiple cancers. J. Med. Genet 2000; 37, 336341.

(2) Chu EC, Tarnawski AS. PTEN regulatory functions in tumor suppression and cell biology. Med. Sci. Monit 2004; 10 (10): RA235-41.

(3) Maehama T and Dixon JE. The tumor suppressor, PTEN/MMAC1, dephosphorylates the lipid second messenger, phosphatidylinositol 3,4,5-trisphosphate. J Biol Chem 2004. 273: $13375-13378$.

(4) Stambolic V, Suzuki A, de la Pompa JL, Brothers GM, Mirtsos C, et al. Negative regulation of $\mathrm{PKB} / \mathrm{Akt}-\mathrm{dependent}$ cell survival by the tumor suppressor PTEN. Cell 1998; 95: 29-39.

(5) Tamura, M., Gu, J., Danen, E.H., Takino, T., Miyamoto, S., and Yamada, K.M. PTEN interactions with focal adhesion kinase and suppression of the extracellular matrix-dependent phosphatidylinositol 3-kinase/Akt cell survival pathway. J. Biol. Chem 1999; 274, 20693-20703.

(6) Torres, J., and Pulido, R. The tumor suppressor PTEN is phosphorylated by the protein kinase CK2 at its C terminus. Implications for PTEN stability to proteasomemediated degradation. J. Biol.Chem 2001; 276:993-998.

(7) Cully, M., You, H., Levine, A.J., and Mak, T.W. Beyond PTEN mutations: the PI3K pathway as an integrator of multiple inputs during tumorigenesis. Nat. Rev. Cancer 2006; 6:184-192.

(8) Lee, S.R., et al. Reversible inactivation of the tumor suppressor PTEN by $\mathrm{H}_{2} \mathrm{O}_{2}$. J. Biol. Chem 2002; 277:20336-20342.

(9) Leslie, N.R., et al. Redox regulation of PI 3-kinase signalling via inactivation of PTEN. EMBO J 2003; 22:5501-5510.

(10)Vazquez, F., Ramaswamy, S., Nakamura, N., and Sellers, W.R. Phosphorylation of the PTEN tail regulates protein stability and function. Mol. Cell. Biol 2000; 20:5010-5018. 
(11)Torres, J., and Pulido, R. The tumor suppressor PTEN is phosphorylated by the protein kinase $\mathrm{CK} 2$ at its $\mathrm{C}$ terminus. Implications for PTEN stability to proteasomemediated degradation. J. Biol.Chem. 2001; 276:993-998.

(12) Lee SR, Yang KS, Kwon J, Lee C, Jeong W, Rhee SG. Reversible inactivation of The tumor suppressor PTEN by H2O2. JBiol Chem 2002; 277: 20336-20342.

(13) Connor KM, Subbaram S, Regan KJ, Nelson KK, Mazurkiewicz JE, Bartholomew $\mathrm{PJ}$, et al. Mitochondrial $\mathrm{H} 2 \mathrm{O} 2$ regulates the angiogenic phenotype via PTEN oxidation. J Biol Chem 2005;280:16916-24.

(14) Diehl JA, ChengM, RousselMF and Sherr CJ. GenesDev., 1998;12, $3499 \pm 3511$.

(15) Piantadosi CA, Suliman HB. (2006) Mitochondrial transcription factor A induction by redox activation of nuclear respiratory factor 1 . J Biol Chem.;281(1):324-33.

(16) Felty, Q., Xiong, W.C., Sun, D., Sarkar, S., Singh, K.P., Parkash, J., and Roy, D. Estrogen- induced mitochondrial reactive oxygen species as signal-transducing messengers. Biochemistry 2005a; 44(18), 6900-6909.

(17) Huo L, Scarpulla RC. Mitochondrial DNA instability and peri-implantation lethality associated with targeted disruption of nuclear respiratory factor 1 in mice. Mol Cell Biol 2001; 21: 644-654, 200.

(18) Cam H, Balciunaite E, Blias A, Spektor A, Scarpulla RC, Young R, Kluger Y, Dynlacht BD. A common set of gene regulatory networks links metabolism and growth inhibition. Mol Cell 2004;16:399-411.

(19) Scarpulla, R. C. J. Cell. Biochem 2006 97, 673-683.

(20) Scarpulla, R. C. Physiol. Rev 2008; 88, 611-638.

(21) Mattingly,K.A., Ivanova,M.M., Riggs,K.A., Wickramasinghe,N.S., Barch,M.J., and Klinge,C.M. Estradiol stimulates transcription of nuclear respiratory factor-1 and Increases mitochondrial biogenesis.Mol.Endocrinol 2008; 22, 609-622.

(22) Watanabe, A. Cloning and characterization of the promoter region of the bovine Membrane tethering protein $\mathrm{p} 115$ gene and its regulation in mammary epithelial cells. Biochim.Biophys.Acta, 2003 1629, 60-72.

(23) Felty Q, Xiong WC, Sun D, Sarkar S, Singh KP, Parkash J, Roy D. EstrogenInduced mitochondrial reactive oxygen species as signal-transducing messengers. Biochemistry 2005; 44: 6900-6909. 
(24) Ha HL, Yu DY. HBx-induced reactive oxygen species activates hepatocellular carcinogenesis via dysregulation of PTEN/Akt pathway. World J Gastroenterol 2010;16(39): 4932-4937.

(25) Silva A, Yunes JA, Cardoso BA. PTEN posttranslational inactivation and hyperactivation of the PI3K/Akt pathway sustain primary T cell leukemia viability. $J$ Clin Invest 2008; 118: 3762-3764.

Figures and Legend

Fig 1-MCF7

A

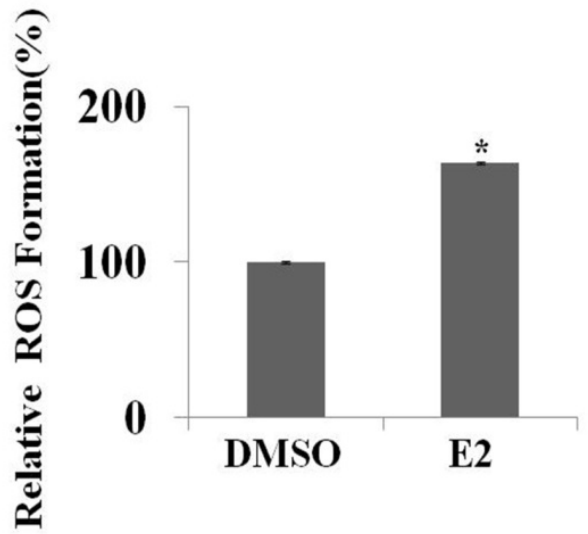

B

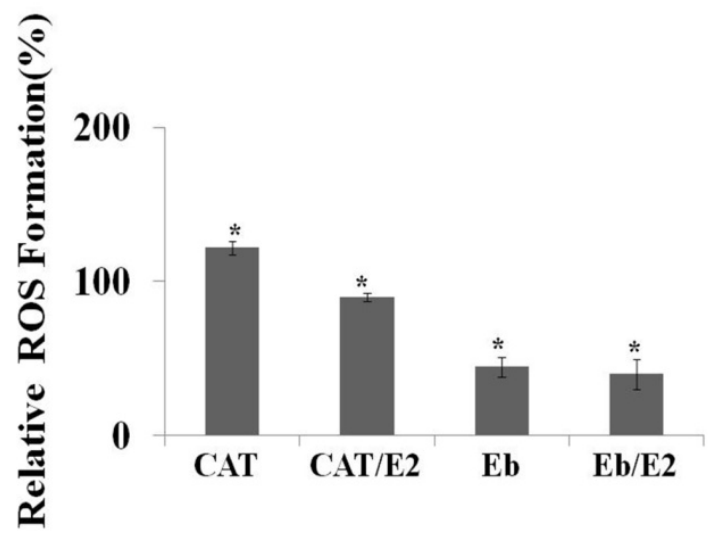

Antioxidants inhibit E2 induced ROS in MCF7 cells. 1 x $10^{4}$ cells/well were seeded in a 96-well plate overnight and serum starved for $24 \mathrm{hrs}$. Post-starvation 100uL/well of HBSS containing 10uM DCFH-DA pre-diluted with Pluronic F-127 was added to each well and incubated at $37^{\circ} \mathrm{C}$ for 20 mins. DCFH-DA solution was then aspirated and replaced with 100ul of HBSS containing the desired treatments. Cells were further incubated for 5mins and fluorescence readings were taken using $485 \mathrm{~nm}$ and $535 \mathrm{~nm}$ as excitation and emission filters, at intervals of 5mins. A) MCF7 cells treated with E2. B) MCF7 cells over expressing Catalase (CAT) or pre-treated with Ebselen were exposed to either E2 or DMSO. Assay was performed 3x and data is expressed as mean percentage 
change from control $+/$ - SE, $\left(p\right.$ 0.05). $\left(^{*}\right)$ denotes significance when treatment is compared to DMSO control.

Fig 2-MCF7

A

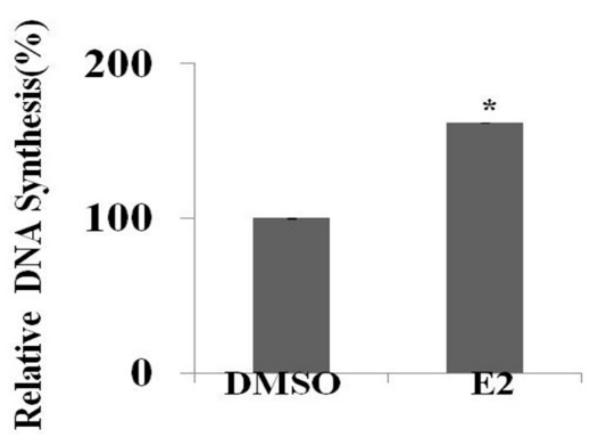

B

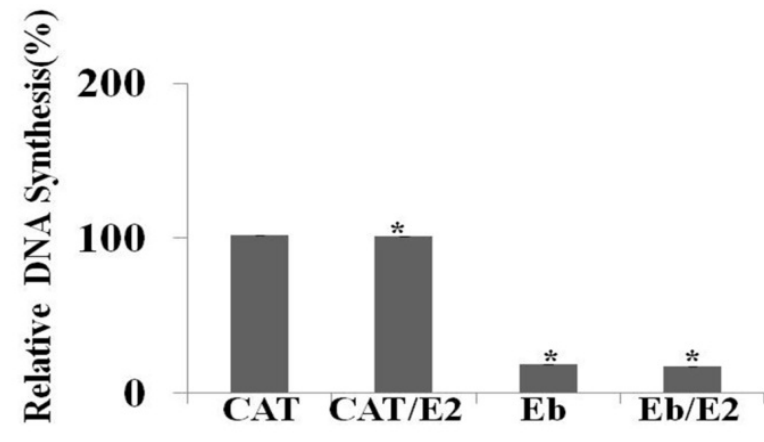

Antioxidants inhibit DNA synthesis in MCF7 cells. $2.5 \times 10^{3}$ cells/well were seeded in a 96-well plate overnight and exposed to chemical or biological antioxidants as described in methods. After exposure to antioxidants, cells were then stimulated with E2 for $22 \mathrm{hrs}$ and pulsed labeled with BrdU for 2 hrs. BrdU assay was then carried out as recommended by manufacturer. Colorimetric changes were acquired at $370 \mathrm{~nm}$ with a Tecan Genios microplate reader at 5 mins interval. A) MCF7 cells treated with either E2 or DMSO B) MCF7 cells over expressing Catalase (CAT) or pre-treated with Ebselen were treated with either E2 or DMSO. Assay was performed 3x and data is expressed as mean percentage change from control $+/-\mathrm{SE},(p 0.05) .\left(^{*}\right)$ denotes significance when treatment is compared to DMSO control. 


\section{Fig 3-MCF7}

A

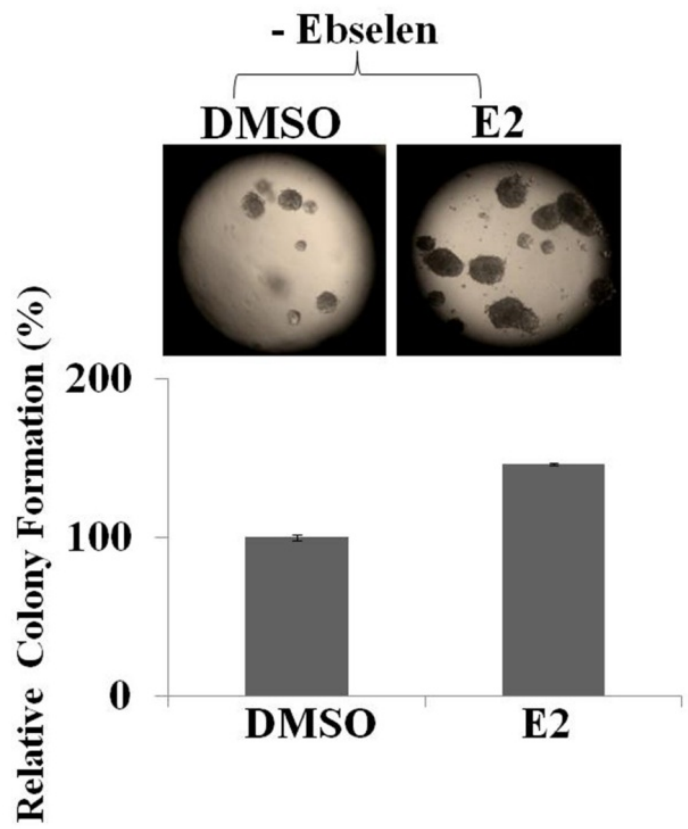

B

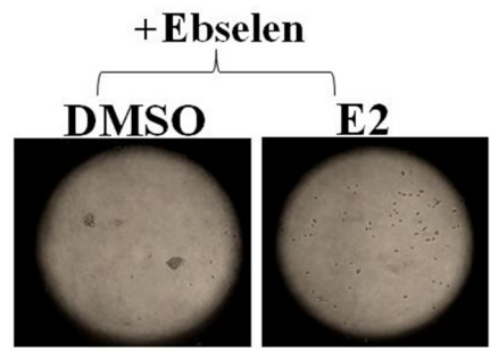

Antioxidants inhibit E2-induced anchorage independent growth in MCF7 cells.

Cells were incubated on soft agar with or without antioxidants exposure for 21 days and colonies $\geq 60$ microns in diameter were enumerated. A) Anchorage independent growth of MCF7 cells exposed to either DMSO or E2 B) MCF7 cells pretreated with chemical antioxidant. Assay performed $3 \mathrm{x}$ and data is expressed as mean percentage change from control. 
Fig 4-MCF7
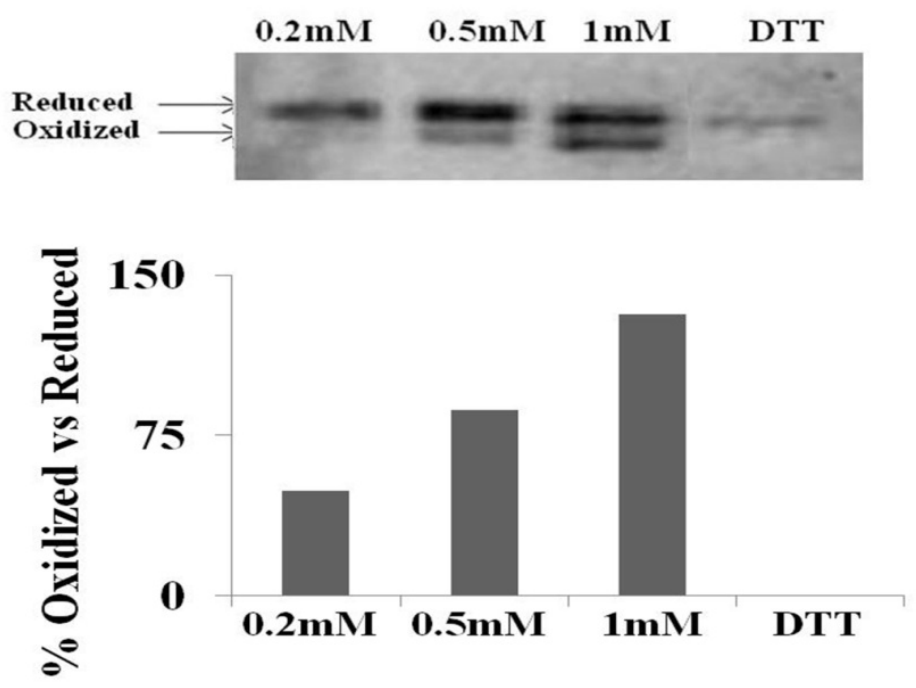

Hydrogen Peroxide $\left(\mathrm{H}_{2} \mathrm{O}_{2}\right)$ oxidizes PTEN in a dose dependent manner in MCF7 cells. MCF7 cells were seeded and stimulated with different doses of $\mathrm{H}_{2} \mathrm{O}_{2}$ for $30 \mathrm{~min}$ and then harvested. Cellular protein extracts were then alkylated with NEM and subjected to non-reducing SDS-PAGE followed by immunoblot analysis with antibodies to PTEN. Assay was performed $3 \mathrm{x}$ and data is expressed as mean percentage change from control. 


\section{Fig 5-MCF7}

A

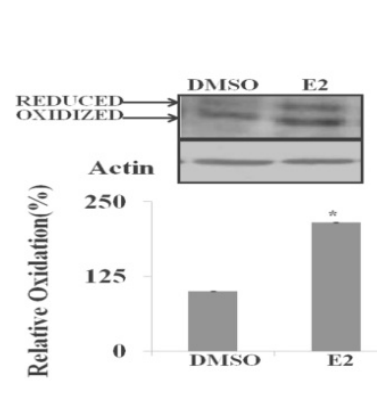

C

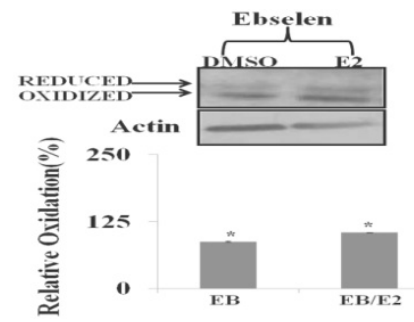

B

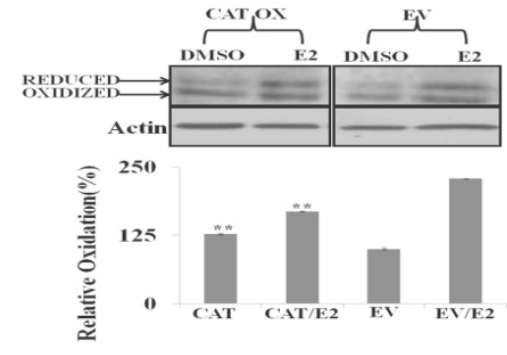

Antioxidants inhibit the E2-induced PTEN oxidation in MCF7 cells. Cells were pretreated with Ebselen for 3hrs and stimulated with either DMSO or E2 for 30mins. Cellular protein extracts were then alkylated with NEM and subjected to nonreducing SDS-PAGE followed by immunoblot analysis with antibodies to PTEN. A) MCF7 cells treated with either E2 or DMSO. B) MCF7 cells over-expressing Catalase (CAT) or Empty Vector (EV) treated with DMSO or E2. C) MCF7 cells pre-treated with Ebselen were treated with either DMSO or E2. Assay was performed 3x and data is expressed as

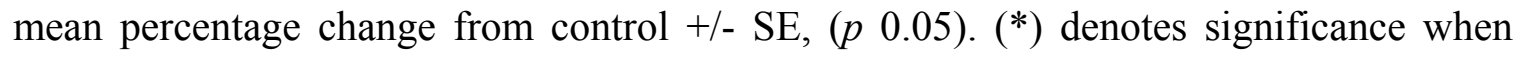
treatment is compared to DMSO control while $(* *)$ denotes significance when treatment is compared EV control. 
Fig 6-MCF7

A

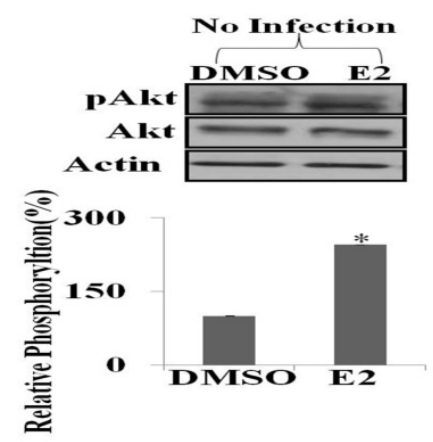

C

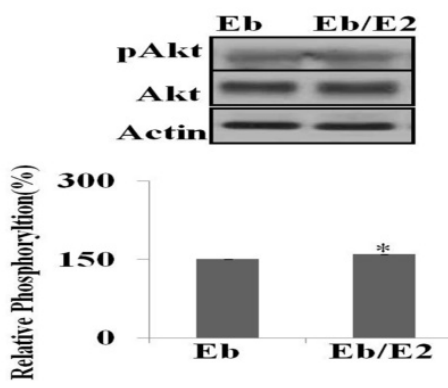

B

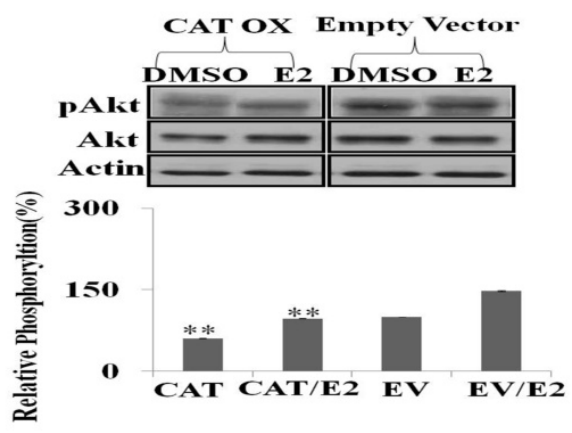

E2-induced PTEN oxidation activates Akt phosphorylation in MCF7 cells. Akt and phospho-Akt levels were determined post PTEN oxidation by immunoblotting using MCF7 cells pre-exposed with either biological (CAT) or chemical (Ebselen) antioxidants and then treated with E2 for 30min to induce PTEN oxidation. A) MCF7 cells treated with either E2 or DMSO B) MCF7 cells over-expressing Catalase (CAT) or Empty Vector (EV) treated with DMSO or E2. C) MCF7 cells pre-treated with Ebselen were treated with either DMSO or E2. Assay was performed 3x and data is expressed as mean percentage change from control $+/-\mathrm{SE},(p 0.05) .\left(^{*}\right)$ denotes significance when treatment is compared to DMSO control while $(* *)$ denotes significance when treatment is compared EV control. 
Fig7-MCF7.

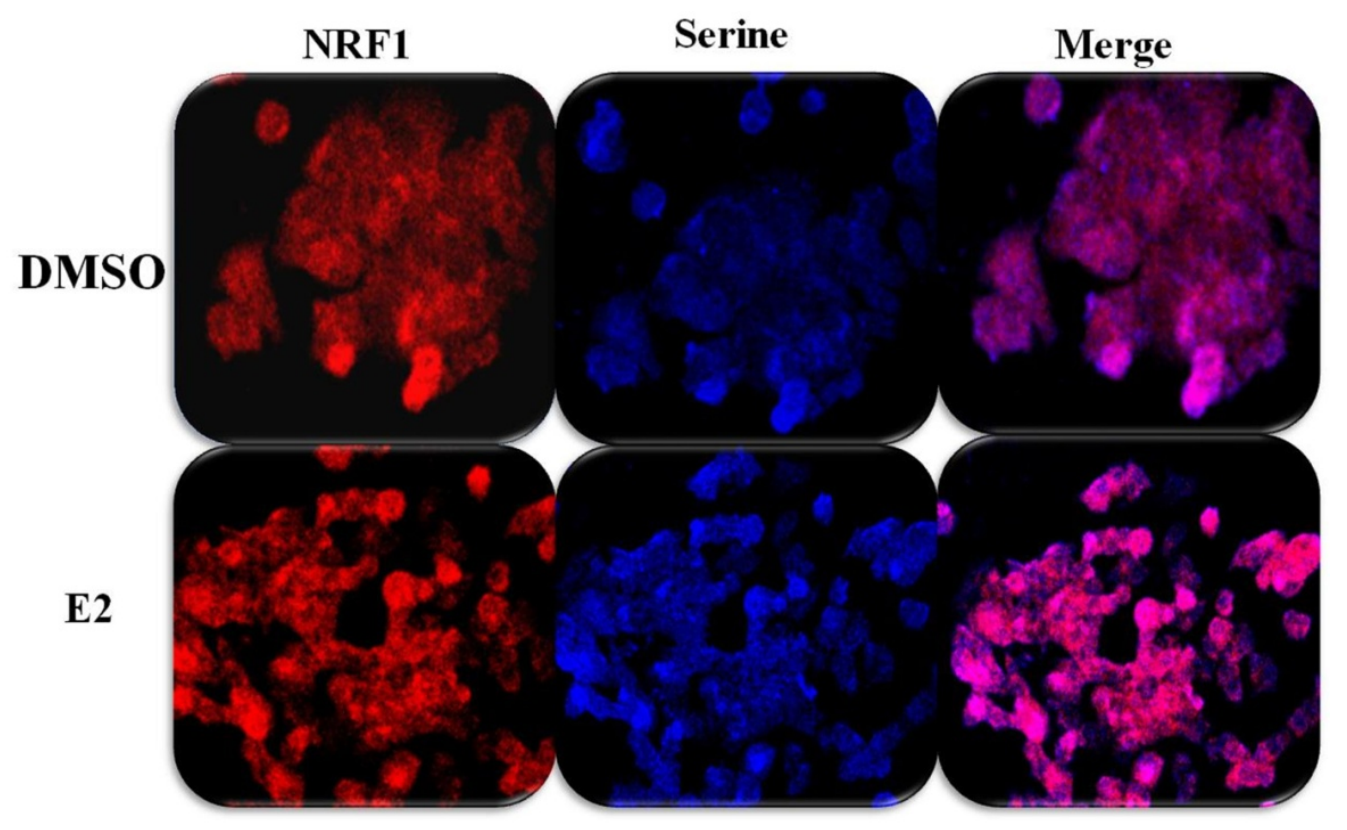

E2 induces NRF1 expression and phosphorylation in MCF7 cells. $1.0 \times 10^{4}$ cells/chamber were treated for $45 \mathrm{mins}$ with E2. Cells were then fixed with ice cold methanol for $15 \mathrm{mins}$, and permeabilized with $0.5 \%$ Triton $\mathrm{X}-100$ for $30 \mathrm{mins}$ after which they were blocked with $1 \%$ normal goat serum for $1 \mathrm{hr}$ and then probed simultaneously with antibodies for NRF1 (red) phosphoserine (blue). The merged phosphorylated NRF1 is in pink. 


\section{Fig 8-MCF7}

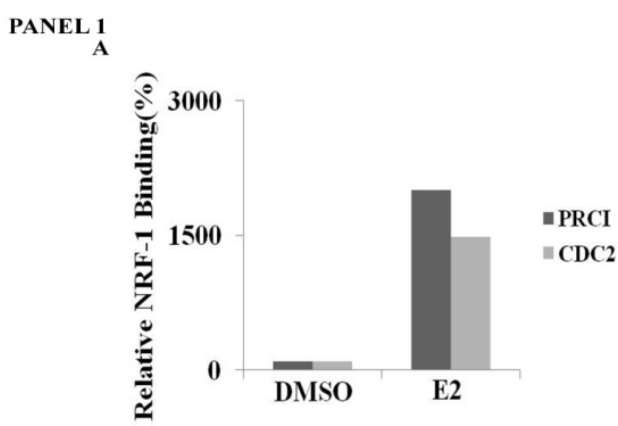

B
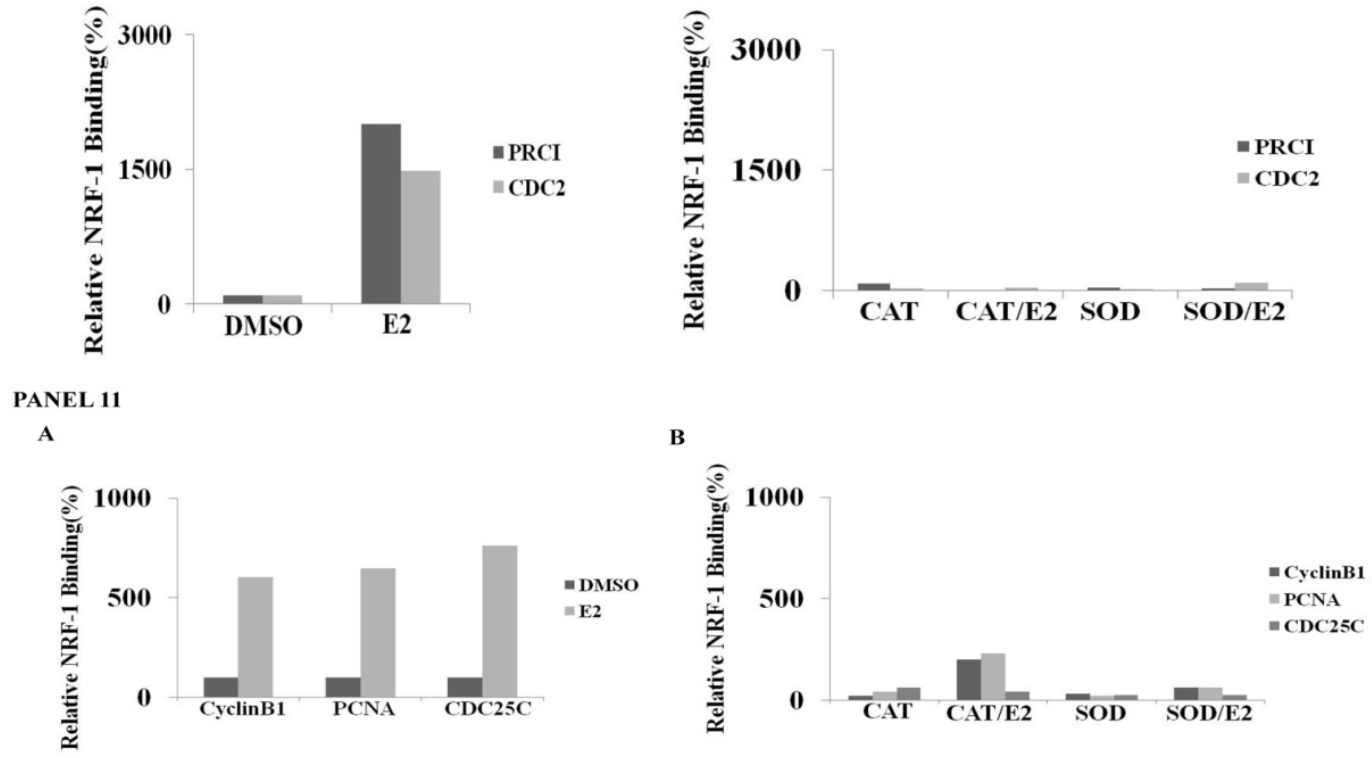

\section{E2-induced ROS mediates NFR-1 binding to the promoter region of cell cycle genes.}

MCF7 cells were seeded, serum starved for $24 \mathrm{hrs}$ and either infected with Adenovirus over- expressing MnSOD (SOD) or Catalase (CAT) at m.o.i of 200pfu as shown in the methods section. Cells were then exposed to either DMSO or E2 for 16hrs and harvested for ChIP assay as described in methods. PCR were run on ABI Biosystem 7300 thermocycler with the following cycle conditions: $95^{\circ} \mathrm{C}, 10 \mathrm{~min} ; 40$ cycles of $\left(95^{\circ} \mathrm{C}, 15\right.$ sec; $\left.60{ }^{\circ} \mathrm{C}, 60 \mathrm{sec}\right)$. PANEL I: PCR were run with primers for PRC1 and CDC2. A) MCF7 cells were treated with either E2 or DMSO B) MCF7cells over expressing CAT or SOD were treated with either DMSO or E2. Assay was performed $3 \mathrm{x}$ and data is expressed as mean percentage change from control. PANELII: PCR were run with primers for PCNA, CyclinB1 and CDC25C. A) MCF7 cells were treated with either E2 or DMSO B) MCF7 cells over expressing CAT or SOD were treated with either DMSO 
or E2. Assays was performed 3x and data is expressed as mean percentage change from control.

\section{Fig 9-MCF7}

PANEL 1

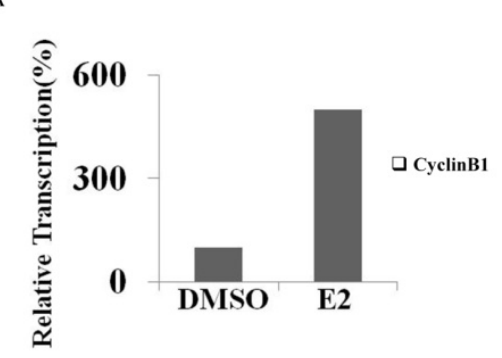

PANEL 11

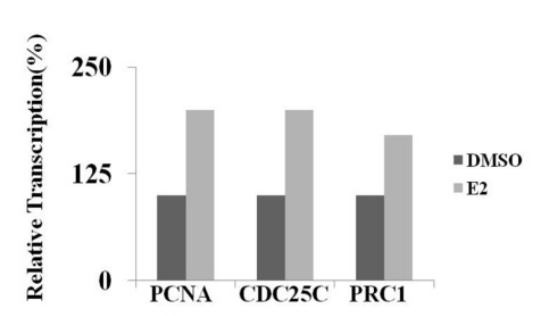

B

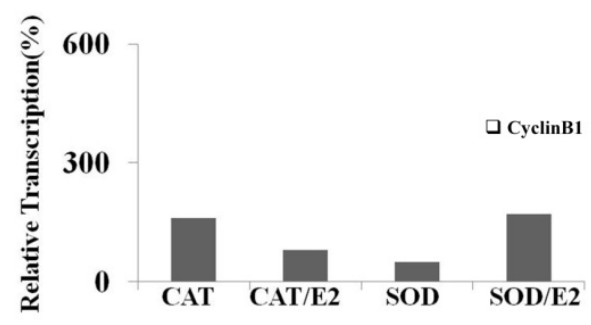

в

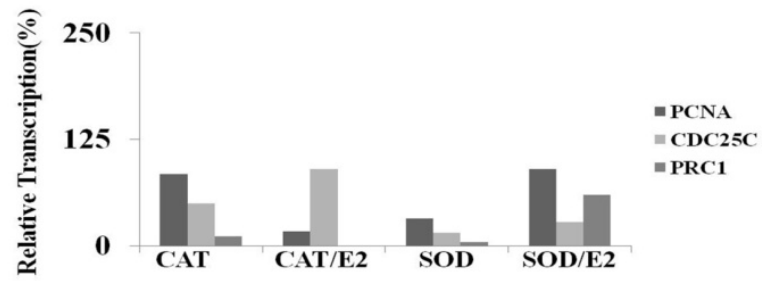

E2-induced ROS mediates transcription of cell cycle genes. MCF7 cells were seeded, serum starved for $24 \mathrm{hrs}$ and either infected with Adenovirus over- expressing MnSOD (SOD) or Catalase (CAT) at m.o.i of 200pfu as shown in the methods section. Cells were then exposed to either DMSO or E2 for $24 \mathrm{hrs}$ and harvested for RT-PCR as described in methods. RT- PCR were run on ABI Biosystem 7300 thermocycler with the following cycle conditions: initial initiation Step set at $48^{\circ} \mathrm{C}$ for $30 \mathrm{mins}$; and $95^{\circ} \mathrm{C}$ for $10 \mathrm{~min}(1$ cycle) and the PCR step at $95^{\circ} \mathrm{C}$ for $15 \mathrm{sec}$ and $60 \mathrm{sec}$ for $1 \mathrm{~min}$ (40 cycle). PANEL I: RTPCR were run with primers for CyclinB1. A) MCF7 cells were treated with either E2 or DMSO B) MCF7cells over expressing CAT or SOD were treated with either DMSO or E2. Assay was performed $3 \mathrm{x}$ and data is expressed as mean percentage change from 
control. PANELII: RT-PCR was run with primers for PCNA, PRC1 and CDC25C. A) MCF7 cells were treated with either E2 or DMSO B) MCF7cells over expressing CAT or SOD were treated with either DMSO or E2. Assays was performed $3 \mathrm{x}$ and data is expressed as mean percentage change from control.

\section{Fig 10-MCF7}

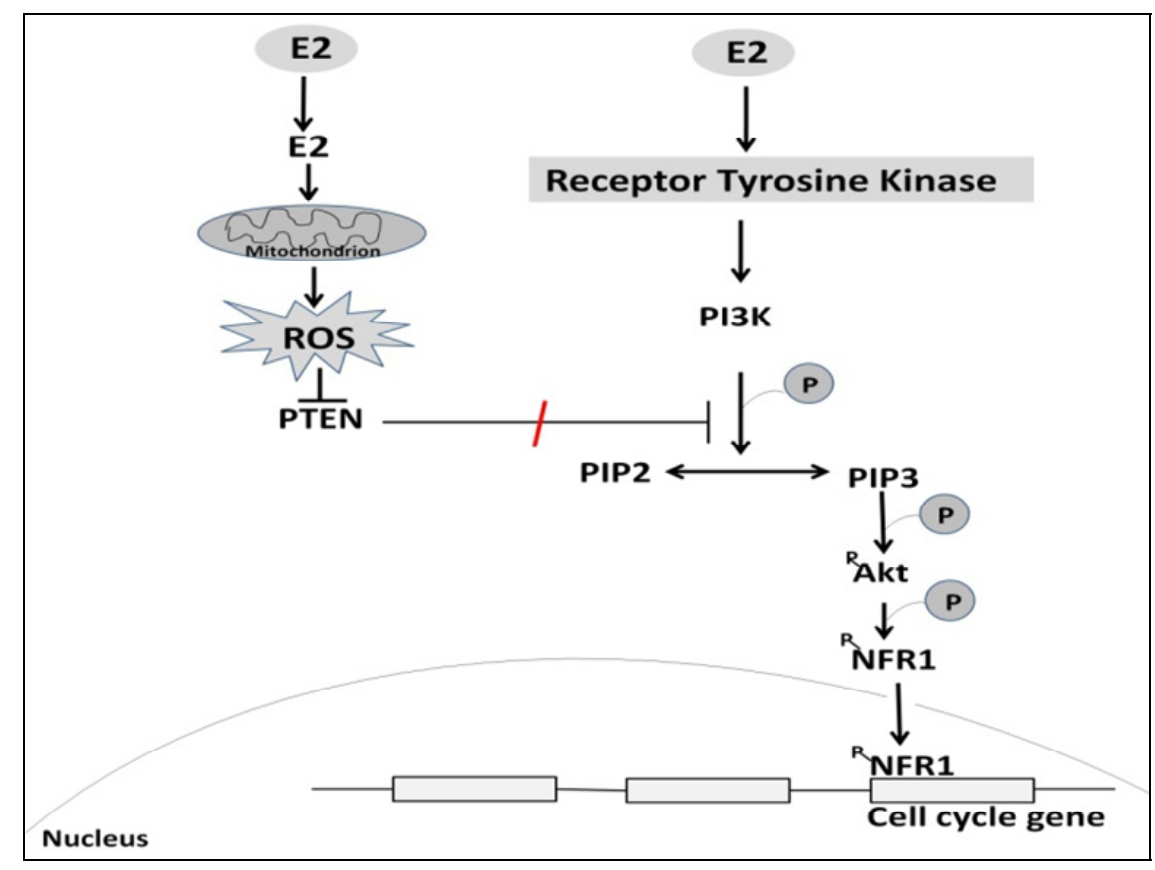

A schematic showing our hypothesized pathway. Estrogen-induced ROS inactivates PTEN with an ensuing increase in Akt phosphorylation. This Increase in Akt phosphorylation results in an increase in NRF1 expression and phosphorylation leading to the activation and binding of NRF1 to the promoter region of some cell cycle genes.

\section{CONCLUSION}

The goal of this dissertation was to investigate and hopefully reveal the role of ROS in the conversion of tamoxifen sensitive breast tumors to a tamoxifen-resistant phenotype. 
Our research was based on the working hypothesis that excess ROS oxidizes protein tyrosine phosphatases (PTPs), thereby changing the phosphorylation state and altering the functions of certain key signaling proteins such as p27 (a Cyclin dependent kinase inhibitor) and nuclear respiratory factor 1(NRF-1) (a transcription factor).We further postulated that if ROS/redox signaling has a role in the development of tamoxifen resistance, then we may be able to restore sensitivity to tamoxifen by pre-exposing resistant breast cancer cells to antioxidants.

In the course of our research, using tamoxifen resistant LCC 2 breast cancer cells, we found tamoxifen to be highly pro-oxidant, based on its ability to induce ROS formation when it is used to stimulate LCC2 cells. We further discovered that tamoxifen acts as an ROS scavenger (antioxidant) in the presence of estrogen. Upon further investigation we found that stimulating LCC2 cells with tamoxifen resulted in a reduction in the expression of p27 protein and an increase in its phosphorylation on threoning 157 and 187 respectively which correlated with an increase in cell proliferation. Interestingly, we were able to reverse these findings using biological (MnSOD and Catalase) and chemical (Ebselen) antioxidants. Meaning that LCC2cells which were pre-exposed to antioxidants showed a significant increase in p27 expression and a reduction in the phosphorylation of p27 implying a possible growth inhibitory effect.

Our findings then raised a question about what aspect of p27 was really affected in the development of tamoxifen resistance. Was it a decrease in p27 expression or just the inability of the protein to carry out its growth inhibitory function? So we compared the 
level of p27 in tamoxifen sensitive MCF7 breast cancer cells to that in tamoxifen resistant breast cancer cells and found that the level of p27 in LCC2 cells was significantly less than in MCF7 demonstrating that if tamoxifen resistance is as a result of a reduction in p27 expression, then our finding that pre-exposure to anti-oxidants $t$ increases p27 expression was a significant one. We then conducted a p27 stability assay comparing cells pre- exposed to anti-oxidant to those which were not. Again we found that those cells pre-exposed to anti-oxidants showed more p27 stability compared to those which were not. We also conducted a functional assay to determine the effect of our findings on the function of $\mathrm{p} 27$, again we found that cells which were pre-exposed to anti-oxidants were more functional because they exhibited more binding capacity of p27 to CyclinE and Cdk2 compared to cells which were not exposed to anti-oxidants. As mentioned previously in this dissertation, the growth inhibitory effect of p 27 is based on its ability to bind to the CylinE-Cdk2 complex.

Putting all our findings together we may therefore infer that, the development of tamoxifen resistance is due to the ability of tamoxifen to produce a sustained increase in ROS which results in a pro-oxidative environment. In a pro-oxidative environment the expression and stability of p27 is diminished resulting in loss of its inhibitory function because there is not enough p27 to bind and inhibit the growth promoting CyclinE-CDK2 complex. Therefore our findings that anti-oxidants increased p27 expression, stability and binding are very significant. 
To determine the mechanism of tamoxifen resistance, we used Tamoxifen sensitive MCF7 cells to determine the effect of ROS on the loss of tamoxifen sensitivity and demonstrated that in a pro-oxidant environment, the sustained increase in ROS level leads to the oxidation and inhibition of the phosphatase PTEN with a consequent increase in the phosphorylation of Akt. An increase in Akt phosphorylation then results in the phosphorylation and activation of NRF-1. We then demonstrated that activated NRF-1 then binds to the promoter region of the following cell cycle genes: PCNA, cyclinB1, CDC25A and PRC1 leading to their transcription and culminating in a sustained cell proliferation. This finding could also be used to explain what happens in the case of p27 because Akt has been shown to phosphorylate p27 on T157 resulting in the cytoplasmic sequestration of $\mathrm{p} 27$ and loss of its inhibitory function.

In a nutshell, we have been able to experimentally demonstrate that ROS/redox signaling contributes to the evolution of breast cancer from a tamoxifen sensitive to a tamoxifen resistant phenotype. The Findings of this study will elucidate the roles of the cellular redox state, redox signaling pathways, PTPs and p27 in anti-estrogen resistance, and may lead to new therapeutic strategies to delay or even prevent this important clinical problem. This is a new line of research that may lay the groundwork for clinical trials of anti-estrogens plus antioxidant-based drugs for the prevention and treatment of estrogendependent breast 


\section{Directions for future research}

As mentioned in the conclusion part of this dissertation, using MCF 7 cells we could also demonstrate the effect of Akt phosphorylation on T157 and subsequently p27 function. We have conducted preliminary studies in our lab and the results are encouraging.

Since our current research was done in vitro, another area for further research would be a test of our hypothesis in vivo. Xenografted tumors in nude mice will be used to determine if ROS inhibitors or glutathione or thioredoxin modifiers can cooperate with antiestrogens to inhibit the proliferation of anti-estrogen-resistant breast cancer cells. Findings of this study will reveal the roles of the cellular redox state, redox signaling pathways and p27/NRF-1 in anti-estrogen resistance, and may lead to new therapeutic strategies to delay or even to prevent this important clinical problem. This is a new line of research that may lay the groundwork for clinical trials of anti-estrogens plus antioxidantbased drugs for the prevention and treatment of estrogen-dependent breast cancer. 
VITA

NANA AISHA GARBA

2000

MBBS

Ahmadu Bello University

Zaria, Nigeria

2006

M.P.H., Environmental Health

Florida International University

Miami, Florida

$2000-2001$

House Officer (First Doctor on call)

Jos University Teaching Hospital

Plateau State, Nigeria.

2001 - Date

Director of Programs (Medical)

Keimo Broadcast International Training Center

Plateau State, Nigeria.

$2002-2003$

Medical Doctor

National Institute for policy and strategic studies

Plateau State, Nigeria.

$2004-2006$

Graduate Assistant

Applied Research Center

Florida International University

Miami, Florida.

$2005-2011$

Graduate Research Assistant

Florida International University

Miami, Florida

$2008-2011$

Ph.D. Candidate, Public Health (Environmental Health)

Florida International University

Miami, Florida

Publications and Abstracts

Garba NA., Roy, D. 2011. Estrogen Induced ROS mediates in vitro cell proliferation and growth through PTEN oxidation and AKT-NRF1 phosphorylation (Prepared for submission). 
Garba, NA., Joyce Slingerland., Roy, D., Felty, Quentin. 2011. The Role of Redox Signaling in the development of Tamoxifen Resistance in Breast Cancer (Prepared for submission)

Garba, NA., Joyce Slingerland., Roy, D. 2011. Redox Signaling Contributes to development of Tamoxifen Resistance in Breast Cancer (Prepared for submission).

Garba, NA., Felty, Q and Roy, D. 2007. Environmental Estrogenic Compound Bisphenol A induced ROS Signaling Molecules and Their Adverse Role in Brain Development. SOT 2007 (Accepted)

Garba, NA., Felty, Q., Slingerland, Joyce, and Roy, D. 2008. Reactive oxygen species (ROS)-induced redox signaling pathways contribute to antiestrogen resistance. Poster and oral presentations, FIU Breast Cancer Symposium, Miami, FL. (Accepted)

Nana-Aisha Garba, Rosalind Penny, Victor Okoh, Quentin Felty, Joyce Slingerland, Deodutta Roy. 2008. Reversible inactivation of CDC25A by estrogen and anti-estrogen induced Reactive oxygen species may be involved in the phosphorylation of P27. Poster presentations, Department of Defense Era of Hope Conference, Baltimore, MD.

Deodutta Roy, Quentin Felty, Victor Okoh, Nana-Aisha Garba. 2008. Inhibition of estrogen-induced growth of breast cancer cells by modulating in situ oxidant levels. Department of Defense Era of Hope Conference, Baltimore, MD.

Aisha Garba, Deodutta Roy, Quentin Felty, Jai Parkash, Joyce Slingerland. 2011. Reactive oxygen species-mediated redox signaling may contribute to the development of antiestrogen resistance in breast cancer. DOD Breast Cancer Research Program Era of Hope 2011 Meeting. 